Article

\title{
Does monetary policy in advanced economies have differentiated effects on portfolio flows to emerging economies?
}

\author{
Marco Hernandez-Vega ${ }^{1 *}$ \\ 1 Directorate General of Economic Research, Banco de Mexico, Mexico; auhernandez@banxico.org.mx \\ * Correspondence: auhernandez@banxico.org.mx
}

Received: 13 February 2020; Accepted: 1 May 2020; Published: 13 May 2020.

\begin{abstract}
This work analyzes whether the monetary policy in advanced economies (the US, the euro area, and the UK) had differentiated effects on portfolio flows from these countries toward EMEs. The results show the following: First, US monetary policy had a bigger impact on bond and equity investment to EMEs than the euro area or UK monetary policy. Second, investors' response to US monetary policy was mostly homogeneous. Among EMEs regions, foreign portfolio investment to Emerging Europe and Latin America was more volatile that than to Emerging Asia, probably because other factors such as investors' preference (in the case of bond flows) or expectations of firms' profits (in the case of equity flows) could play an important role in investors' decisions. These results could be useful for policymakers from EMEs as a benchmark to anticipate differentiated effects in portfolio flows caused by advanced economies' monetary policy.
\end{abstract}

Keywords: Emerging Markets; Foreign Portfolio Investment, Monetary Policy Announcements

JEL codes: E52; F21; F62; G10

\section{Introduction}

Foreign portfolio flows to emerging market economies (EMEs) increased dramatically after the global financial crisis. Researchers have attributed such phenomena to a search for yield behavior by investors facing very low-interest rates and higher global liquidity due to the implementation of unconventional monetary policy measures (UMPs) in advanced economies. As a result, the literature analyzing capital flows became relevant. A fraction of these works reprises the approach from previous studies (Calvo et al. (1993), Fernandez-Arias (1996), Taylor and Sarno (1997), Montiel and Reinhart (1999) and Baek (2006) among others) and focus their efforts in identifying the determinants of capital flows to EMEs. In general, these studies find that both internal (or pull) and external (or push) factors are significant determinants of the entry of foreign capital into EMEs. In particular, Cerutti (2015) confirms that external shocks have the same effect on gross inflows across countries, but that the magnitude of the impact differs among them. Moreover, when contrasting portfolio versus other types of flows the authors found that the first has a strong co-movement, while it is not so high for other flows like foreign direct investment or banking flows (see also Byrne and Fiess (2011), IMF (2011), IMF (2012), Fratzscher (2012), Lo Duca (2012), Bowman et al. (2014) and Ahmed and Zlate (2014)).

Other fraction of the literature studies the impact of the implementation and termination of UMPs, specifically in the US, on portfolio flows to EMEs, as well as the effects of monetary policy normalization. For example, Moore et al. (2013) show that the fall in long-term interest rates produced by large-scale asset purchases (LSAP) pushed foreign capital towards EMEs and reduced their 
sovereign yields. Moreover, the authors highlight that such phenomena could have undesired effects by the time the Federal Reserve normalizes its monetary stance. Lim et al. (2014) found that the quantitative easing programs (QE) had an important role in the dramatic upswing of capital inflows in EMEs after the financial crisis, but that the size of the impact depended on the type of flow. Dahlhaus and Vasishtha (2014) attempted to measure the impact of monetary policy normalization in the US and found that it would have a small negative effect on portfolio flows, but the size of such impact differed across countries.

Within such works, some authors find a certain degree of heterogeneity in the response of portfolio flows to external and internal shocks. For example, Fratzscher (2012) shows that portfolio flows across EMEs diverged quite significantly during the financial crisis and attributes such differences to the particular challenges faced by each country at that time. Moore et al. (2013), Sahay et al. (2014), and Ahmed and Zlate (2014) conclude that the magnitude of the effect of QE1 and QE2 on capital flows to EMEs depend on specific country characteristics. Fratzscher et al. (2016) argue that the effects of the QE programs had differentiated effects for capital flows. In one hand, during the QE1 there was a flight to safety as capitals poured into the US On the other hand QE2, and to a lesser extend QE3, resulted in a significant increase of portfolio flows to EMEs, in what could be described as the search for yield given the extremely low level of US interest rates. Hernandez-Vega (2019) shows that the null hypothesis of slope homogeneity is rejected in a panel of 17 EMEs at all significance levels, suggesting that capital flows may react differently to pull and push factors across countries.

More recent works study the spillover effects of UMPs to individual countries. For instance, Park and Um (2016) find significant spillovers of US UMPs on the Korean bond market as well as on net foreign investment and conclude that Korea is not considered a haven. Using a new high-frequency dataset on bonds and equity in Mexico, Hernandez-Vega (2017) concludes that there is an important effect of US monetary policy announcements on foreign inflows, but with marked differences between these two assets. He also finds evidence in favor of the hypothesis that inflows may react with a lag of up to five days after a monetary event takes place; particularly in the case of bond flows.

In summary, the literature has pointed out that US UMPs have affected portfolio flows distinctly, and that each measure by itself had a different impact, at least in magnitude, across EMEs. Nevertheless, such results may not reflect the entire picture, mainly because only US UMPs have been analyzed even though the euro area (EA), the UK, and Japan have also drawn on similar measures possibly affecting domestic investors' strategies. Should this occurred, then UMPs implemented in the UK could have had differentiated effects on the UK flows to EMEs, for example. Hence, this work contributes to the literature by contrasting the responses of portfolio flows to EMEs to UMPs implemented in three different advanced economies (the US, EA, and the UK).

The objective of this work is to analyze if the monetary policy in advanced economies (the US, EA, and the UK) had differentiated effects on portfolio flows from these economies toward EMEs. This is done in two ways: First, by looking at the response of portfolio flows from a particular developed economy (also referred to as source country) to monetary policy events in that same country (also referred to as domestic monetary policy in the paper). For example, the effects on the US flows to Emerging Asia (E-Asia), Emerging Europe (E-Europe) and Latin America (Latam) after a monetary policy announcement made by the Federal Reserve. Second, by analyzing how portfolio flows from a source country to each emerging region react to monetary measures implemented in other advanced economies (also referred to as foreign monetary policy). For instance, how flows from the US to EMEs reacted to euro area or UK monetary actions. In this sense, this work follows Fratzscher et al. (2016) by taking the perspective of an investor but extends the analysis by including monetary policy events not only in the US but also in the euro area and the UK.

The results show that investors from the US, the EA, and the UK responded mostly in the same way to US monetary policy events. For example, events related to the second quantitative easing program motivated investors to raise bonds (equity) flows to all emerging regions, whilst the taper tantrum made all investors withdraw resources from all regions. The only difference in the response of investors to US policies was the amount injected in or withdrawn from each region. For instance, in 
the percentage of assets under management, Emerging Europe and Latin America saw bigger movements of capital relative to those seen in Emerging Asia. One possible reason for such homogeneous responses to US monetary policy is herding, which according to the literature, it usually plays an important role explaining analogous investment decisions; i.e. given the strong influence that the US has globally, it is not surprising that its policies significantly motivate investors to follow each other closely.

In turn, investors' responses to monetary policy events in other advanced economies (EA and UK) were mixed: In one side, US and EA bond investors' response to UK policies were practically similar as it was the case with that of US and EA equity investors to EA and UK policies. On the other side, the responses of the US, EA, and UK bond investors, as well as those of UK equity investors, to EA policies were mostly different.

A quite unexpected result was the different responses of UK bond and equity investors from that of US and EA domiciled investors to UK monetary policy events. This work posits as possible explanations the timing in which these policies were announced and the possibility that UK investors changed their geographical investment mandate after the crises reducing flows to EMEs. Of course, these may have not been the only factors affecting UK investors' decision to pull out from EMEs, but finding a definite explanation goes beyond the scope of this article.

These findings suggest that after a US monetary policy event, there is a high probability for portfolio flows in EMEs to react in the same way. When policies come from other advanced economies, however, their response could be different. Besides, US policies have bigger effects on flows than those from EA and the UK Finally, the results show that investors' response to monetary policy events is stronger in E-Europe and Latam than in E-Asia; probably because other factors, such as investors preferences (in the case of bonds) or particular expectations of firms' profits (in the case of equity), could be relevant for investors' decisions. These results could be useful for policymakers in EMEs as a benchmark to anticipate differentiated effects in portfolio flows caused by monetary policy in advanced economies.

\section{Flows Data and Monetary Policy Events}

After the financial crisis, there was a significant upsurge of portfolio flows to EMEs supporting the idea that these countries became very attractive for foreign investors searching for higher yield (Figure 1). In particular, EME's resilience to the financial crisis; historically low-interest rates in advanced economies; and a significant increase of global liquidity have been considered among the main factors for such important upsurge in portfolio flows. This period of important capital inflows lasted up to the second half of 2014 when oil prices plummeted deteriorating EMEs' financial conditions and economic outlook. Also, events such as the referendum in the UK in favor of leaving the European Union (Brexit) and the presidential elections in the US increased concerns regarding the implementation of protectionist measures that resulted in episodes of high volatility in international financial markets, thus negatively affecting portfolio inflows. ${ }^{1}$

Recently, most of the recent literature studying portfolio flows prefer the use of high-frequency data when assessing the impact of UMPs. One, if not the most, a popular dataset containing highfrequency information on portfolio flows is the one provided by Emerging Portfolio Fund Research (EPFR hereafter). EPFR gathers information on more than 23,000 equity funds and more than 18,000 bond funds across a vast sample of advanced and emerging economies. Note that EPFR tracks more equity than bond funds. Hence, one important difference concerning Balance of Payment data is that in the former equity flows could be significantly higher than bond flows.

Jotikasthira et al. (2012), Fratzscher (2012) and Fratzscher (2016) state that, although its coverage is only between 5 to 20 percent of the total portfolio investment captured in the Financial Account, EPFR data correlate quite well with that in the Balance of Payments. For instance, EPFR data also

${ }^{1}$ See Fratzscher (2012), Chen et al. (2014 and Fratzscher et al. (2016) for more details on how portfolio flows behave in this periods. 
shows an important upturn in foreign portfolio flows in EMEs after the Financial Crisis in July 2009 (Figure 2 Panels A and B).

Figure 1. Annual Gross Portfolio Flows to Emerging Economies

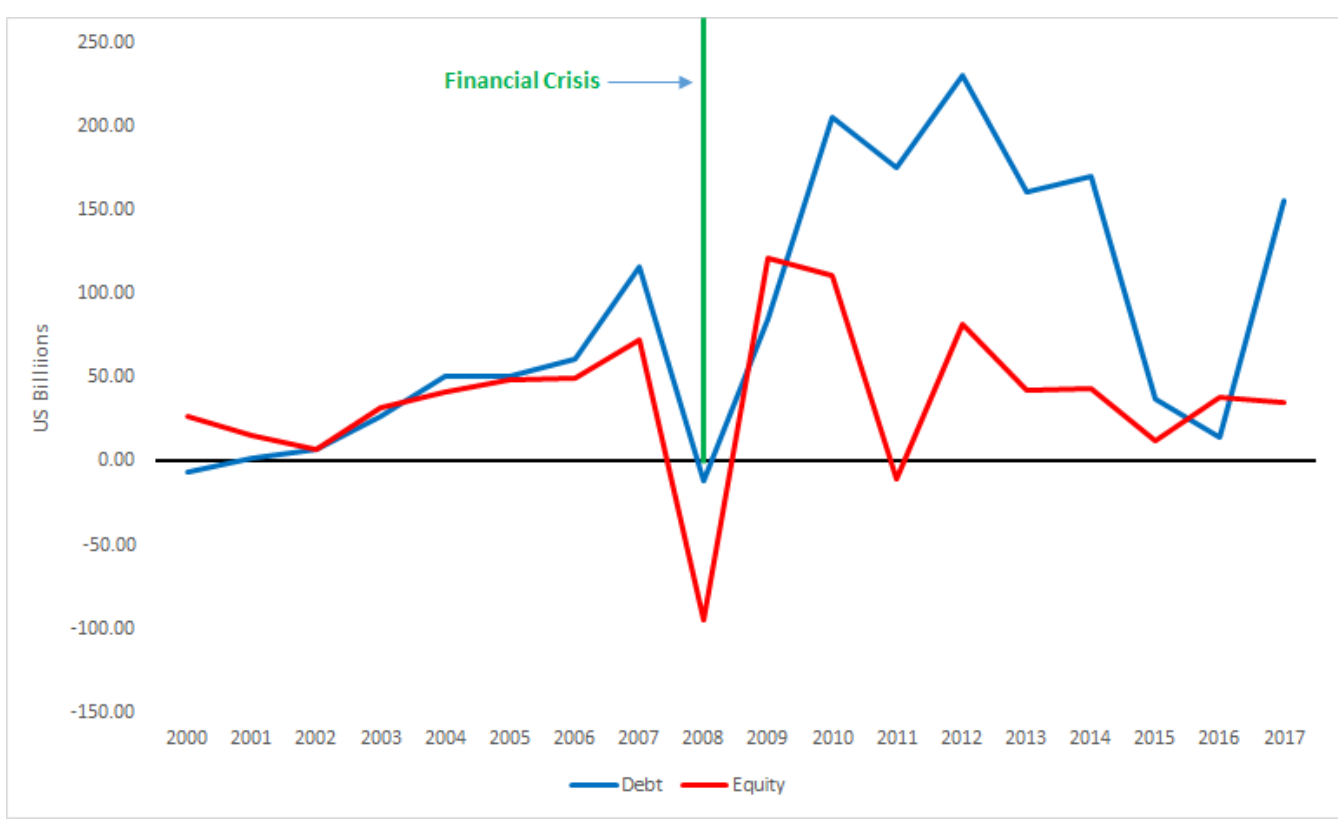

Sample: Brazil, Chile, Colombia, Hungary, India, Indonesia, Israel, Mexico, Peru, Philippines, Poland, Russia, South Africa, South Korea, Thailand, and Turkey. Source: IMF International Balance of Payments Statistics.

Figure 2. Weekly Accumulated Flows to Emerging Economies (in Billions of US Dollars)
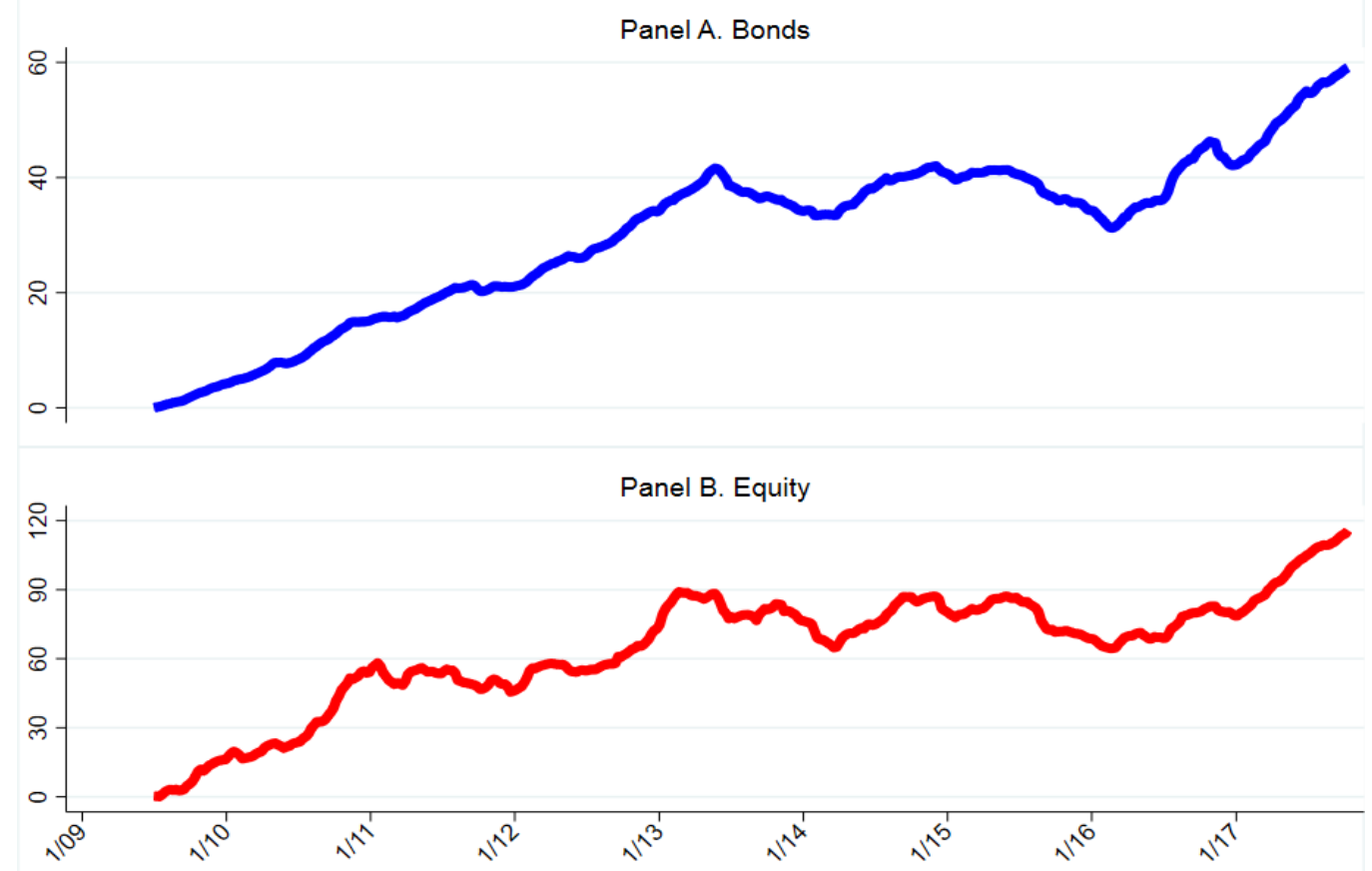

Sample: Brazil, Chile, Colombia, Hungary, India, Indonesia, Israel, Mexico, Peru, Philippines, Poland, Russia, South Africa, South Korea, Thailand, and Turkey. Source: EPFR.

One caveat to keep in mind about EPFR data is that since flows to EMEs are available from 2004 only, they mainly captured the position of funds located in the US. Since 2009, however, EPFR has 
been broadening its sources to include more funds located in other countries; although US investors still are the most important source of debt and equity flows in EMEs (Figures 3 and 4 Panels A to C).

Figure 3. Weekly Accumulated Bond Flows to Emerging Economies by Investors' Domicile (in Billions of US Dollars)
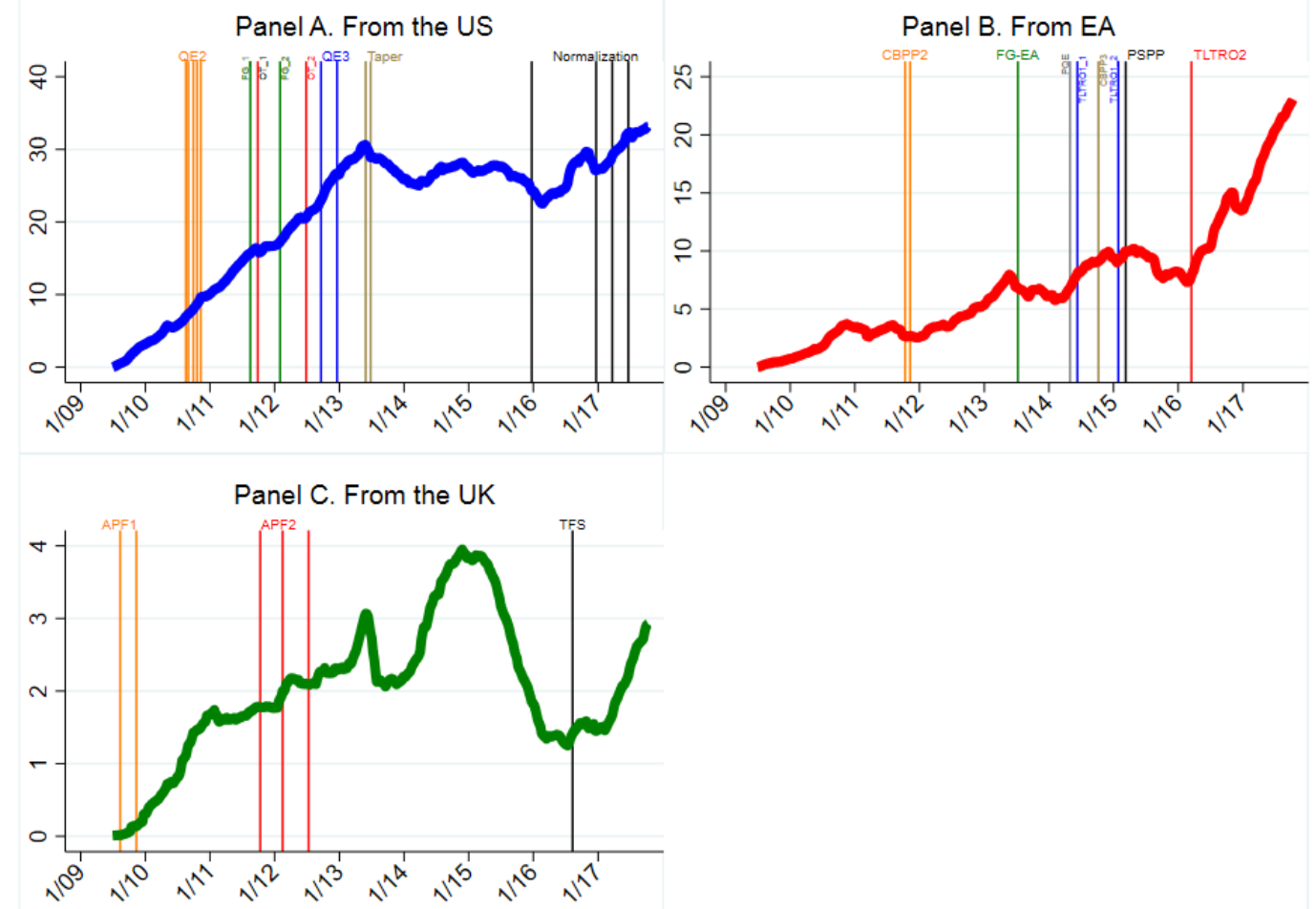

Note. The vertical lines represent monetary policy announcements in the country where the flows are originated. Sample: Brazil, Chile, Colombia, Hungary, India, Indonesia, Israel, Mexico, Peru, Philippines, Poland, Russia, South Africa, South Korea, Thailand, and Turkey. Source: EPFR, Federal Reserve Bank, European Central Bank, Bank of England, and Bloomberg.

Looking at portfolio flows from advanced economies to EMEs, it appears that investors within the same country do not differentiate among emerging regions. For example, bond investment from the US moves identically in E-Asia, E-Europe, and Latam; a situation that also occurs in bond flows from the euro area and the UK (Figure 5). Note that bond flows from EA and UK accelerated since 2016 and 2017, respectively. Among the factors contributing to such recovery we have: First, detailed and clear communication by the Federal Reserve regarding its normalization process, which kept volatility risks low and contributed to a decline in the US dollar. Second, commodity prices recovered improving external balances in commodity-exporting EMEs. Third, China's GDP stabilized at a higher than expected value in 2017. Fourth, more optimistic global growth expectations improved risk appetite and encouraged investors to switch towards riskier assets.

In contrast, the data suggest that equity investors may sometimes invest differently between EMEs. For example, EA investors kept on rising investment in E-Asia from the second half of 2014 up to mid-2015 while reducing it in E-Europe and Latam (Figure 6). It is important to highlight that UK investors have mostly pulled out from EMEs equity since 2015, probably due to internal factors.

As shown by Dahlhaus and Vasishtha (2014), when using EPFR data the main difference in portfolio flows across countries within a specific region is the amount received by each country, but inflows behavior is quite similar among them. Hence, in this work, we left aside the study of individual countries and focus our result to contrast portfolio flows into each region.

The analysis uses a sample of 17 EMEs classified in three groups: Emerging Asia (India, Indonesia, Israel, Korea, Malaysia, Philippines, and Thailand), Emerging Europe (Hungary, Poland, Russia, South 
Africa, and Turkey) and Latin America (Brazil, Chile, Colombia, Mexico, and Peru) denoted E-Asia, EEurope, and Latam, respectively. ${ }^{2}$

Figure 4. Weekly Accumulated Equity Flows to Emerging Economies by Investors' Domicile (in Billions of US Dollars)
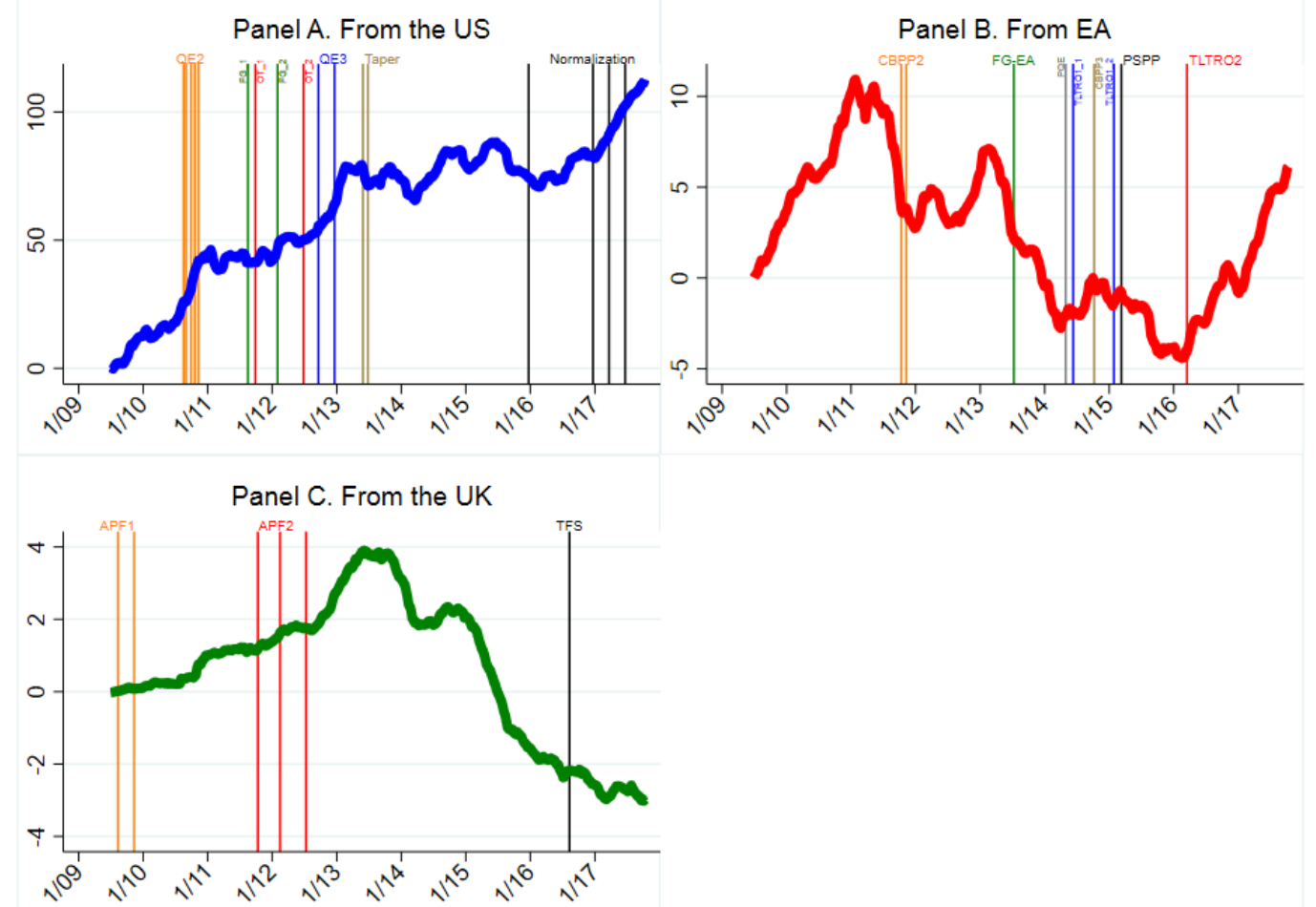

Note. The vertical lines represent monetary policy announcements in the country where the flows are originated. Sample: Brazil, Chile, Colombia, Hungary, India, Indonesia, Israel, Mexico, Peru, Philippines, Poland, Russia, South Africa, South Korea, Thailand, and Turkey. Source: EPFR, Federal Reserve Bank, European Central Bank, Bank of England, and Bloomberg.

Weekly EPFR data on bonds and equity are differentiated by the domicile of the investor, i.e. for each EME, there will be information on inflows from US, EA, and UK investors. Hence, the objective of this work is to contrast the response of flows from different countries towards EMEs to a set of monetary policy events in advanced economies. The data source is EPFR and the period of analysis goes from July 2009 up to the second week of October 2017.

As mentioned above, an important caveat about EPFR data is that flows from the US represent a significant majority of all flows to EMEs. However, this is not the only issue to be taken into account but also changes in the number and size of the reporting funds over time. This usually leads to higher or lower flows in EMEs unrelated to any financial or economic development (such as the monetary policy events used in this work). Hence, it is necessary to control not only for changes in the number of funds included in EPFR's dataset in every period but also for the size of US funds in the data. In this sense, this works follows Fratzscher (2012) and Fratzscher et al. (2016) by expressing flows as a percent of total assets under management (AUM); i.e., weekly bond and equity flow to each emerging economy from any country source will be expressed as a percentage of the value of all assets invested in that country.

Finally, the analysis includes a set of variables representing pull and push factors that are frequently used in the capital flows literature. Pull factors are the nominal exchange rate against the US dollar; country-specific stock indices and short-term interest rates. Push factors, include US 3-

${ }^{2}$ Other EMEs were left out either due to their role as financial centers (Hong-Kong and Singapore), or because of lack of data. 
month OIS rate; EA 3-month swap OIS rate; UK 3-month Libor rate; the VIX index as a proxy for global risk aversion and WTI oil prices. ${ }^{3}$

Figure 5. Weekly Accumulated Bond Flows to Emerging Economies by Region (in Billions of US Dollars)
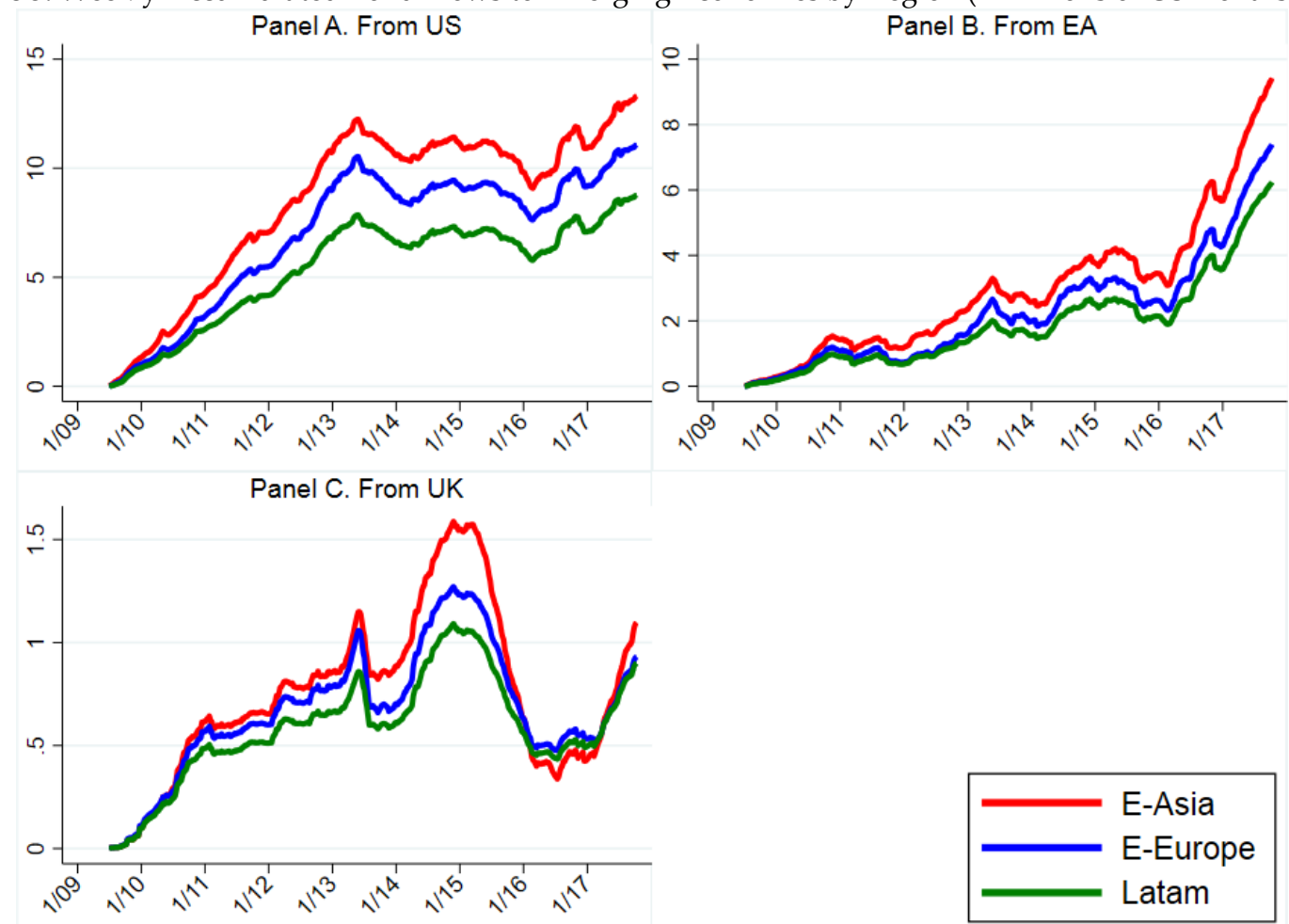

Sample: Brazil, Chile, Colombia, Hungary, India, Indonesia, Israel, Mexico, Peru, Philippines, Poland, Russia, South Africa, South Korea, Thailand, and Turkey. Source: EPFR, Federal Reserve Bank, European Central Bank, Bank of England, and Bloomberg.

\subsection{Monetary Policy Events}

This work considers a broader set of monetary policy actions by including not only those implemented in the US but also those in the euro area and the UK Note that in contrast to the actions in these last two, the US finished its easing cycle and began normalizing its monetary policy stance during the period of analysis. ${ }^{4}$

In the case of the US, expansionary monetary policy measures included are the second quantitative easing program (QE2), which started in the third quarter of 2010, to support economic recovery. This was followed by forwarding guidance announcements (FG), during the third and the first quarters of 2011 and 2012 respectively, directed to convey the message that the Federal Reserve will keep interest rates at a lower level. Similarly, in the third quarter of 2011 operation twist (OT) was announced with the purpose to boost economic activity and was extended in the second quarter of 2012. Finally, and with the same objective as the previous programs, the third quantitative easing program (QE3) was established in 2012. On the other hand, tightening actions comprehend The taper tantrum episode (Taper) that took place in mid-2013 and which led to a spike of volatility in financial markets; and the first four rate hikes made by the Federal Reserve since the last quarter of 2015, as part of the normalization of the monetary policy stance.

\footnotetext{
${ }^{3}$ Data obtained from Bloomberg and Haver Analytics. Summary statistics are shown in Tables A1 to A6 in Appendix A.

4 Timing and details regarding the monetary policy events included in the analysis are shown in Tables B1 to B3 in Appendix B.
} 
Figure 6. Weekly Accumulated Equity Flows to Emerging Economies by Region (in Billions of US Dollars)

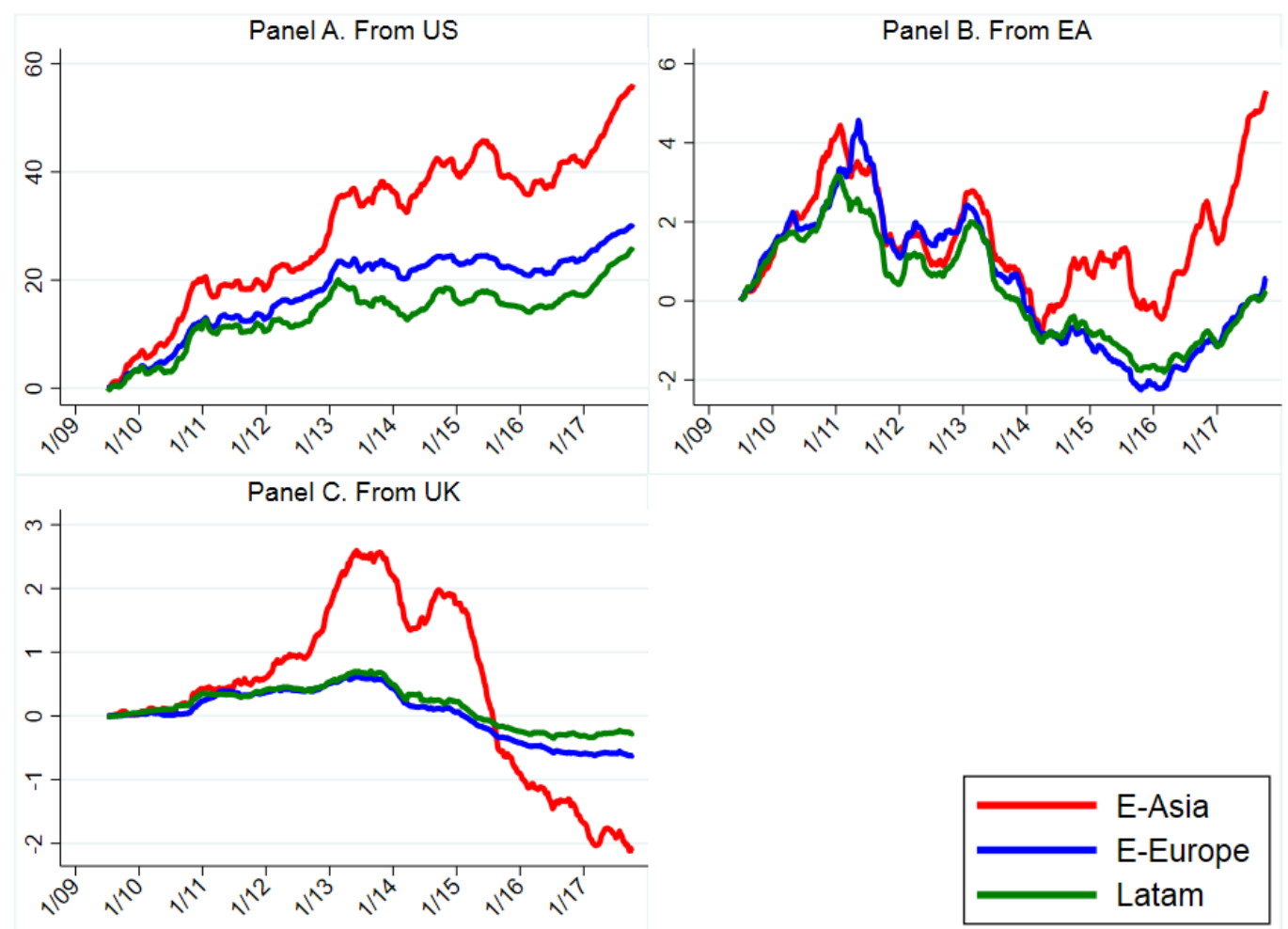

Sample: Brazil, Chile, Colombia, Hungary, India, Indonesia, Israel, Mexico, Peru, Philippines, Poland, Russia, South Africa, South Korea, Thailand, and Turkey. Source: EPFR, Federal Reserve Bank, European Central Bank, Bank of England, and Bloomberg.

For the euro area, we include declarations made by the European Central Bank (ECB) about the second Covered Bond Purchase Programmes (CBPP2) implemented in 2011. The introduction of forwarding guidance (FG_EA) in 2013 by the ECB. The commitment by the ECB to use conventional and unconventional tools (denoted as PQE hereafter) to deal with persistently low inflation in 2014. The third CBPP program (CBPP3) implemented in the last quarter of 2014. The first Targeted LongerTerm Refinancing Operations (TLTRO1) announced in 2014 and extended in early 2015 to motivate lending in the euro area. The Public Sector Purchase Programme (PSPP) in 2015 that allowed the ECB to acquire nominal and inflation-linked government bonds. Lastly, the second Targeted Longer-Term Refinancing Operations (TLTRO2) in early 2016.

Regarding UK monetary policy actions we use Bank of England's first Asset Purchase Facility program (APF1) implemented in 2009; the second Asset Purchase Facility program (APF2) that began in 2011 and was extended twice in 2012; and the Term Funding Scheme in 2016 (TFS).

\section{Methodology}

As shown in Figures 5 and 6, there is a very high correlation in bond/equity inflows between countries within the same region, particularly when these inflows come from the same source country. Thus, should any differences exist in the behavior of foreign portfolio investment they could be observed by making a comparison across regions. First, this is carried out as follows: Let $i=1, \ldots, I$ stand for all countries in region $k=1,2,3$ (representing E-Asia, E-Europe, and Latam respectively); and let $j=$ the US, EA, and the UK. Then, we analyze the impact of monetary policy events implemented in country $j$ on flows from this same $j$ to each $k$ and contrast the results across $k$. This is achieved by estimating a panel event study analysis specified as:

$$
Y_{i, k, t}^{j}=\alpha_{i}+U M P^{j} \beta_{k}^{j}+X_{t-1} \psi_{k}+u_{i, k, t^{\prime}}^{j}
$$


Where $Y_{i, k, t}^{j}$ represents weekly bonds/equity inflows as a percent of AUM to the country $I$ in region $k$ at time $t$ from investors domiciled in country $j ; \alpha_{i}$ captures country fixed effects; $U M P^{j}$ is a $T x N$ matrix where $n=1, \ldots, N$ stands for each monetary policy announcement made in country $j ; X_{t-1}$ is a $T x M$ matrix of pull and push factors introduced with a lag to avoid endogeneity problems. The first includes the percentage change in the exchange rate, the short-run interest rate differentials between economy $i$ and the source country $j$ in the regressions for bonds, and the stock market index in the regressions for equity. As push factors we use the VIX index, in natural logs as is usually used in the related literature, as a proxy for global risk, and the percentage change in WTI oil prices; $\beta_{k}^{j}$ is a NxI vector whose each element represents the response of flows from country $j$ to emerging region $k$ to the $n$th monetary measure implemented in $j ; \psi_{k}$ is a $M x 1$ vector of constants accounting for the impact of pull and push factors. Lastly, $u_{i, k, t}^{j}$ represents the error term. Finally, equation (1) is estimated using Driscoll and Kraay's (1998) standard errors which correct for heteroscedasticity, serial correlation, and cross-section dependence. ${ }^{5}$

Since EPFR weekly portfolio flows data represent inflows to country $i$ from investors domiciled in $j$ accumulated from Thursday to Wednesday, the timing of the announcements becomes relevant when estimating the response of bond and equity inflows. In the US, the Federal Reserve often announces its policy stance on a Wednesday. Considering the time difference between E-Asia and EEurope, as well as with some Latam countries, it is reasonable to think that investors' responses would be observed on Thursday. As a result, we assigned the value of 1 to each element in UMPUs on the week following each announcement. For example, the first taper announcement occurred on Wednesday, May 22, 2013, by the above convention the variable representing this event would be equal to one on the week that begins on May 23 and ends on May 29, 2013.

In turn, a different approach is taken in the cases of the euro area and the UK. In these countries, the announcements take place on Thursdays. Given that by the time of each event it is late Thursday in Asia and early Thursday Latin America, we assigned the value of 1 to each element in UMPEA and UMPUK on that same week in which the event occurred.

In this first stage, the main focus is to contrast each element in $\beta_{k}^{j}$ across EMEs regions. Note that each element in the above vectors represents the reaction of portfolio inflows in percent of AUM from country $j$ to region $k$ to event $n$ in $j$. For example, let $\beta_{k, n}^{j}$ represent the nth element in the vector $\beta_{k}^{j}$ and let $\mathrm{j}=\mathrm{US}$ and $\mathrm{k}=\mathrm{E}-\mathrm{Asia}$. Now, assuming $\beta_{E-A s i a, n}^{U S}>0$ this implies that the nth monetary policy event in the US-led to an increase in inflows from this country to E-Asia. If $\mathrm{k}=\mathrm{E}$-Europe and $\beta_{E-E u r o p e, n}^{U S}<0$ this same event decreased the US flows to E-Europe. As a result, it can be said that the nth event motivated US investors to increase investment in E-Asia and to reduce it in E-Europe.

Second, for all source countries $j$ and all emerging regions $k$ we estimate the impact of policies implemented in source country $l \neq j$ on flows from $j$ to $k$ with the following model:

$$
Y_{i, k, t}^{j}=\alpha_{i}+U M P^{j} \beta_{k}^{j}+U M P^{l} \gamma_{k}^{j, l}+U M P^{p} \delta_{k}^{j, p}+X_{t-1} \psi_{k}+u_{i, k, t}^{j}
$$

Where, as before, $Y_{i, k, t}^{j}$ represents weekly bonds/equity inflows as a percent of AUM to country $i$ in region $k$ at time $t$ from investors domiciled in country $j . U M P^{l}$ and $U M P^{p}$ are $T x G$ and $T x D$ matrices with $g=1, \ldots, G$ and $d=1, \ldots, D$ standing for each monetary policy announcement made in country $l$ and $p$ respectively. $\gamma_{k}^{j, l}$ and $\delta_{k}^{j, p}$ are GxI and Dx1 vectors of constants representing the response of investment from country $j$ to region $k$ to policies implemented in source countries $l$ and $p$ respectively. $\beta_{k}^{j}$ and $\psi_{k}$ are defined as above, and $u_{i, k, t}^{j}$ is the error term.

Thus, for $j=\mathrm{US}, l=\mathrm{EA}, k=\mathrm{E}-\mathrm{Asia}$, and event $g$ if $\beta_{E-A S i a}^{U S, E A}>0 \$$ then such event in the euro area led US investors to augment portfolio flows in E-Asia. In turn, If $\mathrm{k}=$ Latam and $\beta_{\text {Latam }}^{U S, E A}<0$ then this same event led to a flow retrenchment from Latam. Hence, we can say that US investors rose flows to E-Asia

\footnotetext{
${ }^{5}$ Breitung and Das (2005) panel unit root test, which controls for cross-section dependence, confirms that all flow variables are stationary. See Table A8 in Appendix A.
} 
after a monetary policy announcement in the euro area, but that this event led to a fall in those to Latam. As before, equation (2) is estimated using Driscoll and Kraay (1998) standard errors.

\section{Results and Discussion}

This section discusses the results. It begins by contrasting the impact of monetary policy measures in source country $j$ on flows from this economy to each emerging region (equation (1)). Then, it analyzes how monetary policy in one source country affect flows from other sources to each emerging region (equation (2)). At this point, it may be convenient to remember that the purpose of the article is to identify differences, if any, in the responses of portfolio investment towards EMEs to monetary policy events in advanced economies, and it is not to find their determinants.

\subsection{US Monetary Policy and US Investment in EMEs}

Before discussing the response of US investment in EMEs' bond and equity instruments to monetary measures in the US, it is important to highlight that in this particular case the monetary events comprehend not only the implementation and extension of expansionary measures, which involve the quantitative easing programs, forward guidance and operation twist; but also contractionary ones such as the taper tantrum and the normalization of the policy rate.

Regarding US expansionary measures, the results show that QE2 had a significant positive effect in US bond flows to all emerging regions (Table 1 columns 2 to 4). As a percentage of AUM, Latam saw the biggest inflow of US flows followed by E-Europe and E-Asia. A surprising result is that OT announcements led to a retrenchment of US investment in EMEs' bonds. This can be explained by the fact that OT consisted of the Federal Reserve acquiring long-term assets and selling short-term ones, which was taken by investors as a signal of future higher long-term yields in the US reducing the demand for EMEs' assets. Forward guidance had, in general, the expected results by boosting US bond inflows; particularly during the second time, the Federal Reserve confirmed that interest rates were to be kept at extremely low levels (FG_2). Lastly, the implementation of QE3 did motivate US investors to increase their demand for EMEs' bonds, being E-Europe the region that saw flows rising more, as a percentage of AUM, followed by Latam and E-Asia. The extension of this program (QE3_2) increased flows to E-Europe only.

Looking at the response of US bond investors to contractionary policies the results show that the taper tantrum episode had a significant adverse effect on US investment to EMEs; particularly, in EEurope. Similarly, the first two rate hikes implemented by the Federal Reserve led to a retrenchment of US bond flows from all emerging regions. On the other hand, the third rise in the policy rate shows a positive significant effect on US investment in EMEs. Two possible factors may help explain this response: First, by the time this rise took place (March 2017) volatility in international financial markets and uncertainty about the normalization process have receded. Second, a stronger than expected recovery of the global economy; lower political uncertainty in the euro area; and expectations that interest rates will remain low in advanced economies, together with still ample liquidity, led investors to believe that financial costs would remain low for some time. These factors could have motivated investors to search for higher yields increasing the demand for EMEs' bonds. Finally, the fourth rate hike had no significant effect in E-Asia and E-Europe and a relatively smaller negative impact on Latam when compared to the initial interest rate hikes.

Now, concerning US investment in EMEs' equity instruments the results are mostly like those for bonds (qualitatively speaking), but with some differences. First, the hint about extending the second quantitative easing program (QE2_2) had no significant effects. Second, the implementation of Operation Twist (OT_1) drove US investment towards all emerging regions, whilst its extension (OT_2) led to retrenchment. Third, extending the third quantitative easing program (QE3_2) had a positive significant effect only on the US flows to E-Asia and E-Europe. Lastly, the fourth-rate hike harmed the US flows towards E-Europe only (see Table 1 columns 5 to 7). 
Table 1. Effects of US Monetary Policy Measures in US Portfolio Flows to EMEs

\begin{tabular}{|c|c|c|c|c|c|c|}
\hline & \multicolumn{3}{|c|}{ Bonds } & \multicolumn{3}{|c|}{ Equity } \\
\hline & E-Asia & E-Europe & Latam & E-Asia & E-Europe & Latam \\
\hline \multicolumn{7}{|l|}{ Expansionary Measures } \\
\hline QE2_1 & $\begin{array}{c}0.0720^{* * *} \\
(0.0004)\end{array}$ & $\begin{array}{c}0.1697^{* * *} \\
(0.0026)\end{array}$ & $\begin{array}{c}0.2417^{* * *} \\
(0.0056)\end{array}$ & $\begin{array}{c}0.0433^{* * *} \\
(0.0000)\end{array}$ & $\begin{array}{c}0.2083^{* * *} \\
(0.0001)\end{array}$ & $\begin{array}{c}0.1520^{* * *} \\
(0.0003)\end{array}$ \\
\hline QE2_2 & $\begin{array}{c}0.0660^{* * *} \\
(0.0036)\end{array}$ & $\begin{array}{c}0.3001^{* * *} \\
(0.0010)\end{array}$ & $\begin{array}{c}0.2731^{* * *} \\
(0.0088)\end{array}$ & $\begin{array}{l}-0.0047 \\
(0.1612)\end{array}$ & $\begin{array}{l}-0.0095 \\
(0.5174)\end{array}$ & $\begin{array}{l}-0.0048 \\
(0.7749)\end{array}$ \\
\hline QE2_3 & $\begin{array}{c}0.0648^{* * *} \\
(0.0009)\end{array}$ & $\begin{array}{c}0.2640^{* * *} \\
(0.0008)\end{array}$ & $\begin{array}{c}0.3058^{* * *} \\
(0.0017)\end{array}$ & $\begin{array}{c}0.0295^{* * *} \\
(0.0000)\end{array}$ & $\begin{array}{c}0.1160^{* * *} \\
(0.0005)\end{array}$ & $\begin{array}{c}0.0999^{* * *} \\
(0.0009)\end{array}$ \\
\hline QE2_4 & $\begin{array}{c}0.0846^{* * *} \\
(0.0000)\end{array}$ & $\begin{array}{c}0.3325^{* * *} \\
(0.0001)\end{array}$ & $\begin{array}{c}0.3409^{* * *} \\
(0.0006)\end{array}$ & $\begin{array}{c}0.0543^{* * *} \\
(0.0000)\end{array}$ & $\begin{array}{c}0.1715^{* * *} \\
(0.0001)\end{array}$ & $\begin{array}{c}0.2496^{* * *} \\
(0.0000)\end{array}$ \\
\hline QE2_5 & $\begin{array}{c}0.2327^{* * *} \\
(0.0000)\end{array}$ & $\begin{array}{c}0.8641^{* * *} \\
(0.0000)\end{array}$ & $\begin{array}{c}1.0302^{* * *} \\
(0.0000)\end{array}$ & $\begin{array}{c}0.0346^{* * *} \\
(0.0000)\end{array}$ & $\begin{array}{c}0.1010^{* * *} \\
(0.0006)\end{array}$ & $\begin{array}{c}0.0973^{* * *} \\
(0.0018)\end{array}$ \\
\hline OT_1 & $\begin{array}{c}-0.1715^{* * *} \\
(0.0001)\end{array}$ & $\begin{array}{c}-0.6119^{* * *} \\
(0.0002)\end{array}$ & $\begin{array}{c}-0.5935^{* * *} \\
(0.0014)\end{array}$ & $\begin{array}{c}0.0389^{* * *} \\
(0.0010)\end{array}$ & $\begin{array}{c}0.1689^{* * *} \\
(0.0026)\end{array}$ & $\begin{array}{c}0.3334^{* * *} \\
(0.0016)\end{array}$ \\
\hline OT_2 & $\begin{array}{c}-0.0197^{* *} \\
(0.0485)\end{array}$ & $\begin{array}{c}-0.0647+ \\
(0.0588)\end{array}$ & $\begin{array}{c}-0.0961^{* *} \\
(0.0320)\end{array}$ & $\begin{array}{c}-0.0122^{* * *} \\
(0.0009)\end{array}$ & $\begin{array}{c}-0.1041^{* * *} \\
(0.0004)\end{array}$ & $\begin{array}{c}-0.1120^{* * *} \\
(0.0010)\end{array}$ \\
\hline FG_1 & $\begin{array}{c}0.0562 \\
(0.1010)\end{array}$ & $\begin{array}{l}0.2811^{* *} \\
(0.0232)\end{array}$ & $\begin{array}{c}0.1967 \\
(0.1439)\end{array}$ & $\begin{array}{c}0.0290^{* * *} \\
(0.0030)\end{array}$ & $\begin{array}{l}0.1198^{* *} \\
(0.0132)\end{array}$ & $\begin{array}{c}0.0581 \\
(0.1990)\end{array}$ \\
\hline FG_2 & $\begin{array}{c}0.0647^{* * *} \\
(0.0006)\end{array}$ & $\begin{array}{c}0.2533^{* * *} \\
(0.0009)\end{array}$ & $\begin{array}{c}0.1869^{* * *} \\
(0.0043)\end{array}$ & $\begin{array}{c}0.0318^{* * *} \\
(0.0000)\end{array}$ & $\begin{array}{c}0.1684^{* * *} \\
(0.0002)\end{array}$ & $\begin{array}{c}0.1510^{* * *} \\
(0.0002)\end{array}$ \\
\hline QE3_1 & $\begin{array}{c}0.0893^{* * *} \\
(0.0000)\end{array}$ & $\begin{array}{c}0.4116^{* * *} \\
(0.0001)\end{array}$ & $\begin{array}{c}0.2887^{* * *} \\
(0.0003)\end{array}$ & $\begin{array}{c}0.0360^{* * *} \\
(0.0000)\end{array}$ & $\begin{array}{c}0.1932^{* * *} \\
(0.0000)\end{array}$ & $\begin{array}{c}0.3937^{* * *} \\
(0.0000)\end{array}$ \\
\hline QE3_2 & $\begin{array}{c}0.0044 \\
(0.5505)\end{array}$ & $\begin{array}{l}0.0750+ \\
(0.0564)\end{array}$ & $\begin{array}{l}-0.0335 \\
(0.3461)\end{array}$ & $\begin{array}{c}0.0572^{* * *} \\
(0.0000)\end{array}$ & $\begin{array}{c}0.1034^{* * *} \\
(0.0003)\end{array}$ & $\begin{array}{l}-0.0220 \\
(0.1785)\end{array}$ \\
\hline \multicolumn{7}{|l|}{ Contractionary Measures } \\
\hline Taper_1 & $\begin{array}{c}-0.0225^{* *} \\
(0.0148)\end{array}$ & $\begin{array}{c}-0.0882^{* *} \\
(0.0320)\end{array}$ & $\begin{array}{c}-0.0831^{* *} \\
(0.0224)\end{array}$ & $\begin{array}{c}-0.0211^{* * *} \\
(0.0001)\end{array}$ & $\begin{array}{c}-0.0874^{* * *} \\
(0.0008)\end{array}$ & $\begin{array}{c}-0.1931^{* * *} \\
(0.0002)\end{array}$ \\
\hline Taper_2 & $\begin{array}{c}-0.2376^{* * *} \\
(0.0000)\end{array}$ & $\begin{array}{c}-1.0206^{* * *} \\
(0.0000)\end{array}$ & $\begin{array}{c}-0.3831^{* * *} \\
(0.0001)\end{array}$ & $\begin{array}{c}-0.0324^{* * *} \\
(0.0000)\end{array}$ & $\begin{array}{c}-0.2687^{* * *} \\
(0.0000)\end{array}$ & $\begin{array}{l}0.0709+ \\
(0.0517)\end{array}$ \\
\hline Norm_1 & $\begin{array}{c}-0.0791^{* * *} \\
(0.0003)\end{array}$ & $\begin{array}{c}-0.3092^{* * *} \\
(0.0011)\end{array}$ & $\begin{array}{c}-0.2048^{* * *} \\
(0.0047)\end{array}$ & $\begin{array}{c}-0.0226^{* * *} \\
(0.0001)\end{array}$ & $\begin{array}{c}-0.1487^{* * *} \\
(0.0002)\end{array}$ & $\begin{array}{l}0.0438+ \\
(0.0629)\end{array}$ \\
\hline Norm_2 & $\begin{array}{c}-0.0232^{* *} \\
(0.0140)\end{array}$ & $\begin{array}{c}-0.0996^{* *} \\
(0.0227)\end{array}$ & $\begin{array}{c}-0.0808^{* *} \\
(0.0442)\end{array}$ & $\begin{array}{c}-0.0236^{* * *} \\
(0.0000)\end{array}$ & $\begin{array}{c}-0.1033^{* * *} \\
(0.0003)\end{array}$ & $\begin{array}{c}-0.0761^{* *} \\
(0.0112)\end{array}$ \\
\hline Norm_3 & $\begin{array}{c}0.0799 * * * \\
(0.0003)\end{array}$ & $\begin{array}{c}0.3720^{* * *} \\
(0.0012)\end{array}$ & $\begin{array}{c}0.2399^{* * *} \\
(0.0017)\end{array}$ & $\begin{array}{c}0.0284^{* * *} \\
(0.0001)\end{array}$ & $\begin{array}{c}0.2261^{* * *} \\
(0.0001)\end{array}$ & $\begin{array}{c}0.2372^{* * *} \\
(0.0004)\end{array}$ \\
\hline Norm_4 & $\begin{array}{l}-0.0047 \\
(0.5991)\end{array}$ & $\begin{array}{l}-0.0476 \\
(0.2622)\end{array}$ & $\begin{array}{c}-0.0940^{* *} \\
(0.0370)\end{array}$ & $\begin{array}{l}-0.0011 \\
(0.6663)\end{array}$ & $\begin{array}{c}-0.0382^{* *} \\
(0.0366)\end{array}$ & $\begin{array}{c}0.0078 \\
(0.7069)\end{array}$ \\
\hline Pull and Push Factor & & & & & & \\
\hline
\end{tabular}




\begin{tabular}{|c|c|c|c|c|c|c|}
\hline FX-Growth-Ratet-1 & $\begin{array}{c}-0.0125^{* * *} \\
(0.0091)\end{array}$ & $\begin{array}{c}-0.0213^{* *} \\
(0.0138)\end{array}$ & $\begin{array}{c}-0.0405^{* *} \\
(0.0218)\end{array}$ & $\begin{array}{c}-0.0058^{* * *} \\
(0.0094)\end{array}$ & $\begin{array}{c}-0.0149^{* * *} \\
(0.0041)\end{array}$ & $\begin{array}{c}-0.0311^{* * *} \\
(0.0053)\end{array}$ \\
\hline Interest-Rate-Difft-1 & $\begin{array}{l}0.0065^{* *} \\
(0.0232)\end{array}$ & $\begin{array}{l}0.0095^{* *} \\
(0.0416)\end{array}$ & $\begin{array}{c}-0.0544^{* *} \\
(0.0176)\end{array}$ & & & \\
\hline Stocks Returns- 1 & & & & $\begin{array}{c}0.5758^{* * *} \\
(0.0000)\end{array}$ & $\begin{array}{c}2.2788^{* * *} \\
(0.0003)\end{array}$ & $\begin{array}{c}3.4676^{* * *} \\
(0.0019)\end{array}$ \\
\hline VIX $_{\mathrm{t}-1}$ & $\begin{array}{c}0.0024+ \\
(0.0764)\end{array}$ & $\begin{array}{c}0.0052 \\
(0.1417)\end{array}$ & $\begin{array}{c}0.0111+ \\
(0.0614)\end{array}$ & $\begin{array}{l}-0.0000 \\
(0.9804)\end{array}$ & $\begin{array}{l}-0.0000 \\
(0.9879)\end{array}$ & $\begin{array}{c}-0.0034+ \\
(0.0885)\end{array}$ \\
\hline Oil-Pricest-1 & $\begin{array}{l}0.0031^{* *} \\
(0.0278)\end{array}$ & $\begin{array}{l}0.0091+ \\
(0.0755)\end{array}$ & $\begin{array}{c}0.0060 \\
(0.1339)\end{array}$ & $\begin{array}{l}0.0008^{* *} \\
(0.0285)\end{array}$ & $\begin{array}{l}0.0037+ \\
(0.0568)\end{array}$ & $\begin{array}{c}0.0034 \\
(0.1578)\end{array}$ \\
\hline Observations & 3017 & 2113 & 2150 & 3017 & 2113 & 2150 \\
\hline Countries & 7 & 5 & 5 & 7 & 5 & 5 \\
\hline
\end{tabular}

Fixed effects included but not reported. Driscoll and Kraay (1998) robust standard errors correcting for serial correlation, heteroscedasticity, and cross-section dependence in parenthesis; $p$-values in parenthesis; + significant at $10 \%$; ** significant at $5 \%$; *** significant at $1 \%$.

\subsection{EA Monetary Policy and EA Investment in EMEs}

Regarding euro area investment in EMEs' bonds, the results suggest that the implementation of the second Covered Bond Purchase Program (CBPP2) had no significant impact, except for flows to EEurope which rose after the technicalities of this program were announced by the ECB. In turn, the forward guidance statement in July 2013 harmed the euro area bond flows to all emerging regions. Such a result appears to be counterintuitive given that the main message was that interest rates were to be kept low or go lower for an extended period. However, it is important to take into account that by the time the ECB gave such announcement financial markets were still immerse in the taper tantrum episode characterized by the flight-to-quality phenomena.6 Lastly, euro area bond flows to E-Asia and E-Europe increased after other policy events such as the quantitative easing statement, the third CBPP, and the two TLTRO programs (TLTRO1, TLTRO2), whilst those to Latam show no significant reaction. Finally, the Public Securities Purchase Program (PSPP) increased flows to E-Europe only (see Table 2 columns 2 to 4 ).

On the other hand, apart from the negative impact of the forward guidance event, and the positive effect of the first TLTRO; the response of euro area equity investment in EMEs differs from that of a bond investment. In particular, the CBPP3, PSPP, and TLTRO2 had significant negative effects on equity flows (see Table 2 columns 5 to 7). Finding a definite explanation to why these differences came up is somewhat difficult; mainly because equity flows can be influenced not only by foreign or domestic economic shocks but also by specific shocks affecting corporations: for example, euro area investors could have withdrawn from E-Asia equity because they thought corporations in the region would not be as profitable as before; or due to herding behavior among investors (see Lakonishok et al. (1992) and Sias (2004) among others).

\subsection{UK Monetary Policy and UK Investment in EMEs}

Concerning the impact of UK monetary policy measures, the results show that most of them led to a withdrawal of UK investors from EMEs' bonds except the increase in the Asset Purchase Facility in February 2012, which had a positive impact in all regions, and a rise of UK investment in Latam

\footnotetext{
${ }^{6}$ The flight-to-quality phenomena takes place when there is a significant sell-off of what investors consider risky assets and begin to buy safer ones. In this particular case, a risky asset is an emerging market bond and safe assets is a US Treasury.
} 
after the Term Funding Scheme was implemented (see Table 3 columns 2 to 4). One possible contributing factor for these mixed results could be the timing in which such measures were announced (see Table B3). For instance, the first two increases in the APF occurred in the last half of 2009 when financial markets were still recovering from the crisis, and uncertainty was still relatively high. The third APF rise was announced in October 2011 just over a month after the Federal Reserve implemented OT. As this was taken as a sign of higher long-term yields, UK investors could have been substituting EMEs bonds from US Treasuries. The forth APF modification took place in February 2012. At that time there was an improvement in financial markets mainly because of a better US economic outlook. Also, the last AFP increase was close to the extension of OT in the US helping to explain again the observed negative sign.

Table 2. Effects of EA Monetary Policy Measures in EA Portfolio Flows to EMEs

\begin{tabular}{|c|c|c|c|c|c|c|}
\hline & \multicolumn{3}{|c|}{ Bonds } & \multicolumn{3}{|c|}{ Equity } \\
\hline & E-Asia & E-Europe & Latam & E-Asia & E-Europe & Latam \\
\hline CBPP2_1 & $\begin{array}{l}-0.0266 \\
(0.1232)\end{array}$ & $\begin{array}{l}-0.0136 \\
(0.8154)\end{array}$ & $\begin{array}{l}-0.0948 \\
(0.2112)\end{array}$ & $\begin{array}{c}-0.0097^{* * *} \\
(0.0044)\end{array}$ & $\begin{array}{c}-0.0942^{* * *} \\
(0.0036)\end{array}$ & $\begin{array}{c}-0.0891^{* * *} \\
(0.0010)\end{array}$ \\
\hline CBPP2_2 & $\begin{array}{c}0.0029 \\
(0.7855)\end{array}$ & $\begin{array}{l}0.0746+ \\
(0.0867)\end{array}$ & $\begin{array}{c}0.0024 \\
(0.9553)\end{array}$ & $\begin{array}{c}0.0052^{* * *} \\
(0.0070)\end{array}$ & $\begin{array}{c}0.0105 \\
(0.3337)\end{array}$ & $\begin{array}{c}-0.0152+ \\
(0.0735)\end{array}$ \\
\hline FG_EA & $\begin{array}{c}-0.0247^{* * *} \\
(0.0013)\end{array}$ & $\begin{array}{c}-0.0858^{* * *} \\
(0.0074)\end{array}$ & $\begin{array}{c}-0.0839^{* * *} \\
(0.0068)\end{array}$ & $\begin{array}{c}-0.0092^{* * *} \\
(0.0000)\end{array}$ & $\begin{array}{c}-0.0471^{* * *} \\
(0.0002)\end{array}$ & $\begin{array}{c}-0.0361^{* * *} \\
(0.0014)\end{array}$ \\
\hline PQE & $\begin{array}{c}0.0288^{* * *} \\
(0.0001)\end{array}$ & $\begin{array}{l}0.0522^{* *} \\
(0.0272)\end{array}$ & $\begin{array}{c}-0.0101 \\
(0.3488)\end{array}$ & $\begin{array}{l}0.0013+ \\
(0.0551)\end{array}$ & $\begin{array}{c}0.0056 \\
(0.1801)\end{array}$ & $\begin{array}{l}0.0104^{* *} \\
(0.0326)\end{array}$ \\
\hline СВРP3 & $\begin{array}{l}0.0087^{* *} \\
(0.0432)\end{array}$ & $\begin{array}{l}0.0434^{* *} \\
(0.0368)\end{array}$ & $\begin{array}{c}-0.0028 \\
(0.8123)\end{array}$ & $\begin{array}{c}-0.0019^{* *} \\
(0.0240)\end{array}$ & $\begin{array}{c}-0.0294^{* * *} \\
(0.0010)\end{array}$ & $\begin{array}{c}-0.0558^{* * *} \\
(0.0002)\end{array}$ \\
\hline TLTRO1_1 & $\begin{array}{c}0.0297^{* * *} \\
(0.0002)\end{array}$ & $\begin{array}{c}0.4569^{* * *} \\
(0.0000)\end{array}$ & $\begin{array}{c}-0.0030 \\
(0.8141)\end{array}$ & $\begin{array}{c}0.0031^{* * *} \\
(0.0029)\end{array}$ & $\begin{array}{l}0.0145^{* *} \\
(0.0248)\end{array}$ & $\begin{array}{c}0.0037 \\
(0.4062)\end{array}$ \\
\hline TLTRO1_2 & $\begin{array}{c}0.0298^{* * *} \\
(0.0004)\end{array}$ & $\begin{array}{c}0.1851^{* * *} \\
(0.0004)\end{array}$ & $\begin{array}{l}-0.0119 \\
(0.4860)\end{array}$ & $\begin{array}{c}0.0050^{* * *} \\
(0.0001)\end{array}$ & $\begin{array}{l}-0.0046 \\
(0.3326)\end{array}$ & $\begin{array}{l}0.0061+ \\
(0.0897)\end{array}$ \\
\hline PSPP & $\begin{array}{c}0.0054 \\
(0.1282)\end{array}$ & $\begin{array}{l}0.0390+ \\
(0.0594)\end{array}$ & $\begin{array}{l}-0.0160 \\
(0.1486)\end{array}$ & $\begin{array}{c}-0.0019^{* * *} \\
(0.0092)\end{array}$ & $\begin{array}{l}-0.0033 \\
(0.4038)\end{array}$ & $\begin{array}{l}-0.0095 \\
(0.1424)\end{array}$ \\
\hline TLTRO2 & $\begin{array}{l}0.0194^{* *} \\
(0.0421)\end{array}$ & $\begin{array}{c}0.1294^{* * *} \\
(0.0091)\end{array}$ & $\begin{array}{c}0.0212 \\
(0.4843)\end{array}$ & $\begin{array}{c}-0.0050^{* * *} \\
(0.0015)\end{array}$ & $\begin{array}{c}-0.0516^{* * *} \\
(0.0008)\end{array}$ & $\begin{array}{c}-0.0264^{* *} \\
(0.0133)\end{array}$ \\
\hline Pull and Push Factor & & & & & & \\
\hline FX-Growth-Ratet-1 & $\begin{array}{c}-0.0107^{* * *} \\
(0.0012)\end{array}$ & $\begin{array}{c}-0.0227^{* * *} \\
(0.0069)\end{array}$ & $\begin{array}{c}-0.0285^{* * *} \\
(0.0072)\end{array}$ & $\begin{array}{c}-0.0058^{* * *} \\
(0.0094)\end{array}$ & $\begin{array}{c}-0.0149^{* * *} \\
(0.0041)\end{array}$ & $\begin{array}{c}-0.0311^{* * *} \\
(0.0053)\end{array}$ \\
\hline Interest-Rate-Difft-1 & $\begin{array}{c}-0.0015+ \\
(0.0823)\end{array}$ & $\begin{array}{c}0.0014 \\
(0.4681)\end{array}$ & $\begin{array}{c}-0.0133+ \\
(0.0720)\end{array}$ & $\begin{array}{c}-0.0020^{* * *} \\
(0.0019)\end{array}$ & $\begin{array}{c}-0.0050^{* *} \\
(0.0111)\end{array}$ & $\begin{array}{c}-0.0073^{* *} \\
(0.0138)\end{array}$ \\
\hline Stocks Returns- 1 & & & & $\begin{array}{c}0.0901^{* * *} \\
(0.0003)\end{array}$ & $\begin{array}{c}0.4854^{* * *} \\
(0.0026)\end{array}$ & $\begin{array}{c}0.6097^{* * *} \\
(0.0044)\end{array}$ \\
\hline VIX $_{\mathrm{t}-1}$ & $\begin{array}{c}-0.0003 \\
(0.5779)\end{array}$ & $\begin{array}{c}-0.0051+ \\
(0.0781)\end{array}$ & $\begin{array}{l}-0.0005 \\
(0.8363)\end{array}$ & $\begin{array}{c}-0.0002+ \\
(0.0755)\end{array}$ & $\begin{array}{l}-0.0010 \\
(0.1812)\end{array}$ & $\begin{array}{c}-0.0010+ \\
(0.0799)\end{array}$ \\
\hline Oil-Pricest-1 & $\begin{array}{c}0.0002 \\
(0.8141)\end{array}$ & $\begin{array}{c}0.0000 \\
(0.9891)\end{array}$ & $\begin{array}{l}-0.0002 \\
(0.9525)\end{array}$ & $\begin{array}{c}0.0001 \\
(0.3795)\end{array}$ & $\begin{array}{c}0.0010 \\
(0.1018)\end{array}$ & $\begin{array}{c}0.0004 \\
(0.4478)\end{array}$ \\
\hline
\end{tabular}




\begin{tabular}{c|ccc|ccc} 
& & & & & & \\
Observations & 3017 & 2113 & 2150 & 3017 & 2113 & 2150 \\
Countries & 7 & 5 & 5 & 7 & 5 & 5 \\
\hline
\end{tabular}

Fixed effects included but not reported. Driscoll and Kraay (1998) robust standard errors correcting for serial correlation, heteroscedasticity, and cross-section dependence in parenthesis. P-values in parenthesis, + significant at $10 \% ; * *$ significant at $5 \% ; * * *$ significant at $1 \%$.

The response of UK equity flows to EMEs was somewhat different than the one for UK bond flows. In particular, APF announcements increased equity flows to E-Asia and Latam, while bond flows to E-Europe were initially not affected. Finally, the TFS had a negative significant impact on equity flows to E-Asia and E-Europe but a positive one in Latam. Note that, similarly for the case of bonds, the APF announcement in February 2012 had a significant positive effect in UK equity flows to all emerging regions (see Table 3 columns 5 to 7 ).

Table 3. Effects of UK Monetary Policy Measures in UK Portfolio Flows to EMEs

\begin{tabular}{|c|c|c|c|c|c|c|}
\hline & \multicolumn{3}{|c|}{ Bonds } & \multicolumn{3}{|c|}{ Equity } \\
\hline & E-Asia & E-Europe & Latam & E-Asia & E-Europe & Latam \\
\hline APF1_2 & $\begin{array}{c}-0.0066^{* *} \\
(0.0357)\end{array}$ & $\begin{array}{c}-0.0221^{* *} \\
(0.0456)\end{array}$ & $\begin{array}{c}-0.0426^{* *} \\
(0.0185)\end{array}$ & $\begin{array}{l}0.0006^{* *} \\
(0.0273)\end{array}$ & $\begin{array}{l}-0.0006 \\
(0.3529)\end{array}$ & $\begin{array}{c}0.0005 \\
(0.5602)\end{array}$ \\
\hline APF1_3 & $\begin{array}{c}-0.0139^{* * *} \\
(0.0011)\end{array}$ & $\begin{array}{c}-0.0369^{* * *} \\
(0.0083)\end{array}$ & $\begin{array}{c}-0.0879^{* * *} \\
(0.0017)\end{array}$ & $\begin{array}{c}-0.0006^{* *} \\
(0.0161)\end{array}$ & $\begin{array}{c}-0.0011 \\
(0.1256)\end{array}$ & $\begin{array}{l}-0.0007 \\
(0.4235)\end{array}$ \\
\hline APF2_1 & $\begin{array}{c}-0.0148^{* *} \\
(0.0211)\end{array}$ & $\begin{array}{c}-0.0410+ \\
(0.0598)\end{array}$ & $\begin{array}{c}-0.0643^{* *} \\
(0.0309)\end{array}$ & $\begin{array}{l}0.0008+ \\
(0.0776)\end{array}$ & $\begin{array}{c}0.0004 \\
(0.7083)\end{array}$ & $\begin{array}{c}0.0113^{* * *} \\
(0.0011)\end{array}$ \\
\hline APF2_2 & $\begin{array}{c}0.0386^{* * *} \\
(0.0000)\end{array}$ & $\begin{array}{c}0.1254^{* * *} \\
(0.0000)\end{array}$ & $\begin{array}{c}0.1293^{* * *} \\
(0.0000)\end{array}$ & $\begin{array}{c}0.0065^{* * *} \\
(0.0000)\end{array}$ & $\begin{array}{c}0.0043^{* * *} \\
(0.0010)\end{array}$ & $\begin{array}{c}0.0033^{* * *} \\
(0.0083)\end{array}$ \\
\hline APF2_3 & $\begin{array}{c}-0.0110^{* * *} \\
(0.0011)\end{array}$ & $\begin{array}{c}-0.0341^{* * *} \\
(0.0076)\end{array}$ & $\begin{array}{c}-0.0371^{* * *} \\
(0.0032)\end{array}$ & $\begin{array}{c}0.0010^{* * *} \\
(0.0056)\end{array}$ & $\begin{array}{c}-0.0076^{* * *} \\
(0.0002)\end{array}$ & $\begin{array}{c}-0.0034^{* *} \\
(0.0110)\end{array}$ \\
\hline TFS & $\begin{array}{l}-0.0006 \\
(0.7794)\end{array}$ & $\begin{array}{c}0.0078 \\
(0.3400)\end{array}$ & $\begin{array}{l}0.0199^{* *} \\
(0.0410)\end{array}$ & $\begin{array}{c}-0.0018^{* * *} \\
(0.0015)\end{array}$ & $\begin{array}{c}-0.0049^{* * *} \\
(0.0026)\end{array}$ & $\begin{array}{c}0.0084^{* * *} \\
(0.0018)\end{array}$ \\
\hline \multicolumn{7}{|l|}{ Pull and Push Factors } \\
\hline FX-Growth-Ratet-1 & $\begin{array}{c}-0.0022^{* *} \\
(0.0140)\end{array}$ & $\begin{array}{l}-0.0030+ \\
(0.0726)\end{array}$ & $\begin{array}{c}-0.0052^{* *} \\
(0.0297)\end{array}$ & $\begin{array}{c}-0.0058^{* * *} \\
(0.0094)\end{array}$ & $\begin{array}{c}-0.0149^{* * *} \\
(0.0041)\end{array}$ & $\begin{array}{c}-0.0311^{* * *} \\
(0.0053)\end{array}$ \\
\hline Interest-Rate-Difft-1 & $\begin{array}{l}0.0007^{* *} \\
(0.0279)\end{array}$ & $\begin{array}{c}0.0004 \\
(0.4678)\end{array}$ & $\begin{array}{c}-0.0086^{* *} \\
(0.0181)\end{array}$ & $\begin{array}{c}-0.0002+ \\
(0.0550)\end{array}$ & $\begin{array}{l}-0.0003 \\
(0.1609)\end{array}$ & $\begin{array}{l}-0.0006 \\
(0.1380)\end{array}$ \\
\hline Stocks Returns-1 & & & & $\begin{array}{c}0.0223^{* * *} \\
(0.0055)\end{array}$ & $\begin{array}{c}0.0559^{* * *} \\
(0.0086)\end{array}$ & $\begin{array}{l}0.0468+ \\
(0.0847)\end{array}$ \\
\hline $\mathrm{VIX}_{\mathrm{t}-1}$ & $\begin{array}{c}0.0003 \\
(0.1659)\end{array}$ & $\begin{array}{c}0.0007 \\
(0.3448)\end{array}$ & $\begin{array}{c}0.0016 \\
(0.1009)\end{array}$ & $\begin{array}{c}0.0000 \\
(0.2319)\end{array}$ & $\begin{array}{l}0.0001^{* *} \\
(0.0366)\end{array}$ & $\begin{array}{c}0.0001 \\
(0.1577)\end{array}$ \\
\hline Oil-Pricest-1 & $\begin{array}{c}0.0001 \\
(0.6218)\end{array}$ & $\begin{array}{c}0.0006 \\
(0.5196)\end{array}$ & $\begin{array}{c}0.0004 \\
(0.6545)\end{array}$ & $\begin{array}{c}0.0000 \\
(0.8799)\end{array}$ & $\begin{array}{c}0.0001 \\
(0.5219)\end{array}$ & $\begin{array}{c}0.0000 \\
(0.8104)\end{array}$ \\
\hline Observations & 3017 & 2113 & 2150 & 3017 & 2113 & 2150 \\
\hline Countries & 7 & 5 & 5 & 7 & 5 & 5 \\
\hline
\end{tabular}

Fixed effects included but not reported. Driscoll and Kraay (1998) robust standard errors correcting for serial correlation, heteroscedasticity, and cross-section dependence in parenthesis. P-values in parenthesis, + significant at $10 \% ; *$ significant at $5 \% ; * * *$ significant at $1 \%$. 


\subsection{Investors' Response to Advanced Economies Monetary Policy Measures}

The previous results show how investors domiciled in advanced economies reacted to domestic monetary policy measures, but policies implemented in other source countries could also have some effect on their investment strategies. At this point is also important to highlight that the response of investors domiciled in advanced economies to domestic monetary policy measures remains practically unchanged to the inclusion of policy announcements in other source countries.

Looking at US bond investment in EMEs after EA policies, the results show that the CBPP2 led to mixed responses. On one hand, US bond flows to EMEs fell after the first announcement, then those to E-Europe rose after the second with no significant effect on other flows. Similarly, to the response of EA investors, US investors reduced flows to emerging regions after the F_EA announcement and increased those to E-Asia and E-Europe after the CBPP3. In contrast, all other policies led to a retrenchment of US bond flows from all emerging regions. In turn, US bond flows mostly increased after UK monetary policy measures, which is a remarkable difference concerning the mostly negative response from UK investors to these same events (see Table 4 columns 2-4).

US equity investors also had a mixed reaction to the CBPP2, increasing investment to Latam after the first announcement with no significant response in the other regions. As in the case above, after the FG_EA announcement US equity flows to all regions fell while those to E-Asia and E-Europe rose after the PQE. US equity investors' response was quite like that from EA investors in many cases, falling after the CBPP3 and the PSPP then rising after the first TLTRO. Regarding the second TLTRO, US equity flows increased investment in Latam only. US investors' response to APF announcements was mostly positive in E-Asia and E-Europe, while after the TFS the US flows to all regions increased, particularly in E-Europe and Latam (see Table 4 columns 5-7).

Table 4. Effects of Advanced Economies Monetary Policy Measures in US Portfolio Flows to EMEs

\begin{tabular}{|c|c|c|c|c|c|c|}
\hline & \multicolumn{3}{|c|}{ Bonds } & \multicolumn{3}{|c|}{ Equity } \\
\hline & E-Asia & E-Europe & Latam & E-Asia & E-Europe & Latam \\
\hline US Expansionary Measures & & & & & & \\
\hline QE2_1 & $\begin{array}{c}0.0724^{* * *} \\
(0.0004)\end{array}$ & $\begin{array}{c}0.1718^{* * *} \\
(0.0027)\end{array}$ & $\begin{array}{c}0.2437^{* * *} \\
(0.0061)\end{array}$ & $\begin{array}{c}0.0433^{* * *} \\
(0.0000)\end{array}$ & $\begin{array}{c}0.2087^{* * *} \\
(0.0001)\end{array}$ & $\begin{array}{c}0.1549^{* * *} \\
(0.0003)\end{array}$ \\
\hline QE2_2 & $\begin{array}{c}0.0665^{* * *} \\
(0.0037)\end{array}$ & $\begin{array}{c}0.3001^{* * *} \\
(0.0011)\end{array}$ & $\begin{array}{c}0.2741^{* * *} \\
(0.0094)\end{array}$ & $\begin{array}{l}-0.0044 \\
(0.2049)\end{array}$ & $\begin{array}{l}-0.0080 \\
(0.6008)\end{array}$ & $\begin{array}{l}-0.0007 \\
(0.9673)\end{array}$ \\
\hline QE2_3 & $\begin{array}{c}0.0652^{* * *} \\
(0.0009)\end{array}$ & $\begin{array}{c}0.2668^{* * *} \\
(0.0008)\end{array}$ & $\begin{array}{c}0.3070^{* * *} \\
(0.0018)\end{array}$ & $\begin{array}{c}0.0300^{* * *} \\
(0.0000)\end{array}$ & $\begin{array}{c}0.1177^{* * *} \\
(0.0005)\end{array}$ & $\begin{array}{c}0.1026^{* * *} \\
(0.0008)\end{array}$ \\
\hline QE2_4 & $\begin{array}{c}0.0849^{* * *} \\
(0.0000)\end{array}$ & $\begin{array}{c}0.3354^{* * *} \\
(0.0001)\end{array}$ & $\begin{array}{c}0.3428^{* * *} \\
(0.0006)\end{array}$ & $\begin{array}{c}0.0544^{* * *} \\
(0.0000)\end{array}$ & $\begin{array}{c}0.1724^{* * *} \\
(0.0001)\end{array}$ & $\begin{array}{c}0.2516^{* * *} \\
(0.0000)\end{array}$ \\
\hline QE2_5 & $\begin{array}{c}0.2332^{* * *} \\
(0.0000)\end{array}$ & $\begin{array}{c}0.8664^{* * *} \\
(0.0000)\end{array}$ & $\begin{array}{c}1.0315^{* * *} \\
(0.0000)\end{array}$ & $\begin{array}{c}0.0349^{* * *} \\
(0.0000)\end{array}$ & $\begin{array}{c}0.1016^{* * *} \\
(0.0006)\end{array}$ & $\begin{array}{c}0.0996^{* * *} \\
(0.0017)\end{array}$ \\
\hline OT_1 & $\begin{array}{c}-0.1711^{* * *} \\
(0.0001)\end{array}$ & $\begin{array}{c}-0.6127^{* * *} \\
(0.0003)\end{array}$ & $\begin{array}{c}-0.5965^{* * *} \\
(0.0014)\end{array}$ & $\begin{array}{c}0.0379^{* * *} \\
(0.0014)\end{array}$ & $\begin{array}{c}0.1682^{* * *} \\
(0.0030)\end{array}$ & $\begin{array}{c}0.3380^{* * *} \\
(0.0015)\end{array}$ \\
\hline OT_2 & $\begin{array}{c}-0.0193+ \\
(0.0555)\end{array}$ & $\begin{array}{c}-0.0613+ \\
(0.0693)\end{array}$ & $\begin{array}{c}-0.0946^{* *} \\
(0.0371)\end{array}$ & $\begin{array}{c}-0.0120^{* * *} \\
(0.0013)\end{array}$ & $\begin{array}{c}-0.1032^{* * *} \\
(0.0004)\end{array}$ & $\begin{array}{c}-0.1102^{* * *} \\
(0.0013)\end{array}$ \\
\hline FG_1 & $\begin{array}{l}0.0565+ \\
(0.0982)\end{array}$ & $\begin{array}{l}0.2782^{* *} \\
(0.0247)\end{array}$ & $\begin{array}{c}0.1945 \\
(0.1506)\end{array}$ & $\begin{array}{c}0.0294^{* * *} \\
(0.0035)\end{array}$ & $\begin{array}{l}0.1233^{* *} \\
(0.0138)\end{array}$ & $\begin{array}{c}0.0661 \\
(0.1522)\end{array}$ \\
\hline FG_2 & $\begin{array}{c}0.0652^{* * *} \\
(0.0007)\end{array}$ & $\begin{array}{c}0.2585^{* * *} \\
(0.0008)\end{array}$ & $\begin{array}{c}0.1888^{* * *} \\
(0.0046)\end{array}$ & $\begin{array}{c}0.0320^{* * *} \\
(0.0000)\end{array}$ & $\begin{array}{c}0.1704^{* * *} \\
(0.0002)\end{array}$ & $\begin{array}{c}0.1531^{* * *} \\
(0.0002)\end{array}$ \\
\hline
\end{tabular}




\begin{tabular}{|c|c|c|c|c|c|c|}
\hline QE3_1 & $\begin{array}{c}0.0895^{* * *} \\
(0.0000)\end{array}$ & $\begin{array}{c}0.4154^{* * *} \\
(0.0001)\end{array}$ & $\begin{array}{c}0.2904^{* * *} \\
(0.0003)\end{array}$ & $\begin{array}{c}0.0365^{* * *} \\
(0.0000)\end{array}$ & $\begin{array}{c}0.1942^{* * *} \\
(0.0000)\end{array}$ & $\begin{array}{c}0.3946^{* * *} \\
(0.0000)\end{array}$ \\
\hline QE3_2 & $\begin{array}{c}0.0043 \\
(0.5662)\end{array}$ & $\begin{array}{l}0.0755+ \\
(0.0575)\end{array}$ & $\begin{array}{l}-0.0316 \\
(0.3731)\end{array}$ & $\begin{array}{c}0.0575^{* * *} \\
(0.0000)\end{array}$ & $\begin{array}{c}0.1048^{* * *} \\
(0.0002)\end{array}$ & $\begin{array}{l}-0.0210 \\
(0.1968)\end{array}$ \\
\hline \multicolumn{7}{|c|}{ US Contractionary Measures } \\
\hline Taper_1 & $\begin{array}{c}-0.0229^{* *} \\
(0.0150)\end{array}$ & $\begin{array}{c}-0.0900^{* *} \\
(0.0321)\end{array}$ & $\begin{array}{c}-0.0840^{* *} \\
(0.0230)\end{array}$ & $\begin{array}{c}-0.0211^{* * *} \\
(0.0001)\end{array}$ & $\begin{array}{c}-0.0878^{* * *} \\
(0.0008)\end{array}$ & $\begin{array}{c}-0.1944^{* * *} \\
(0.0002)\end{array}$ \\
\hline Taper_2 & $\begin{array}{c}-0.2377^{* * *} \\
(0.0000)\end{array}$ & $\begin{array}{c}-1.0183^{* * *} \\
(0.0000)\end{array}$ & $\begin{array}{c}-0.3822^{* * *} \\
(0.0001)\end{array}$ & $\begin{array}{c}-0.0330^{* * *} \\
(0.0000)\end{array}$ & $\begin{array}{c}-0.2698^{* * *} \\
(0.0000)\end{array}$ & $\begin{array}{l}0.0709+ \\
(0.0581)\end{array}$ \\
\hline Norm_1 & $\begin{array}{c}-0.0792^{* * *} \\
(0.0003)\end{array}$ & $\begin{array}{c}-0.3113^{* * *} \\
(0.0012)\end{array}$ & $\begin{array}{c}-0.2066^{* * *} \\
(0.0044)\end{array}$ & $\begin{array}{c}-0.0220^{* * *} \\
(0.0001)\end{array}$ & $\begin{array}{c}-0.1464^{* * *} \\
(0.0002)\end{array}$ & $\begin{array}{l}0.0456+ \\
(0.0558)\end{array}$ \\
\hline Norm_2 & $\begin{array}{c}-0.0233^{* *} \\
(0.0138)\end{array}$ & $\begin{array}{c}-0.0992^{* *} \\
(0.0237)\end{array}$ & $\begin{array}{c}-0.0794^{* *} \\
(0.0458)\end{array}$ & $\begin{array}{c}-0.0236^{* * *} \\
(0.0000)\end{array}$ & $\begin{array}{c}-0.1034^{* * *} \\
(0.0004)\end{array}$ & $\begin{array}{c}-0.0765^{* *} \\
(0.0121)\end{array}$ \\
\hline Norm_3 & $\begin{array}{c}0.0794^{* * *} \\
(0.0004)\end{array}$ & $\begin{array}{c}0.3707^{* * *} \\
(0.0013)\end{array}$ & $\begin{array}{c}0.2391^{* * *} \\
(0.0018)\end{array}$ & $\begin{array}{c}0.0291^{* * *} \\
(0.0001)\end{array}$ & $\begin{array}{c}0.2289^{* * *} \\
(0.0001)\end{array}$ & $\begin{array}{c}0.2365^{* * *} \\
(0.0005)\end{array}$ \\
\hline Norm_4 & $\begin{array}{c}-0.0052 \\
(0.5731)\end{array}$ & $\begin{array}{l}-0.0487 \\
(0.2634)\end{array}$ & $\begin{array}{c}-0.0934^{* *} \\
(0.0384)\end{array}$ & $\begin{array}{l}-0.0008 \\
(0.7719)\end{array}$ & $\begin{array}{c}-0.0371^{* *} \\
(0.0415)\end{array}$ & $\begin{array}{c}0.0065 \\
(0.7574)\end{array}$ \\
\hline \multicolumn{7}{|c|}{ EA Monetary Policy Measures } \\
\hline CBPP2_1 & $\begin{array}{c}-0.0571 \\
(0.1009)\end{array}$ & $\begin{array}{c}-0.1589+ \\
(0.0888)\end{array}$ & $\begin{array}{c}-0.2594+ \\
(0.0838)\end{array}$ & $\begin{array}{c}-0.0031 \\
(0.6568)\end{array}$ & $\begin{array}{c}0.0330 \\
(0.3579)\end{array}$ & $\begin{array}{l}0.1655^{* *} \\
(0.0106)\end{array}$ \\
\hline CBPP2_2 & $\begin{array}{c}0.0222 \\
(0.2560)\end{array}$ & $\begin{array}{c}0.2353^{* * *} \\
(0.0042)\end{array}$ & $\begin{array}{c}0.1361 \\
(0.1266)\end{array}$ & $\begin{array}{l}-0.0027 \\
(0.6117)\end{array}$ & $\begin{array}{c}0.0429 \\
(0.1023)\end{array}$ & $\begin{array}{l}0.0931^{* *} \\
(0.0163)\end{array}$ \\
\hline FG_EA & $\begin{array}{c}-0.0816^{* * *} \\
(0.0000)\end{array}$ & $\begin{array}{c}-0.2785^{* * *} \\
(0.0003)\end{array}$ & $\begin{array}{c}-0.2400^{* * *} \\
(0.0009)\end{array}$ & $\begin{array}{c}-0.0294^{* * *} \\
(0.0000)\end{array}$ & $\begin{array}{c}-0.0980^{* * *} \\
(0.0005)\end{array}$ & $\begin{array}{l}-0.0309 \\
(0.1522)\end{array}$ \\
\hline PQE & $\begin{array}{c}-0.0424^{* * *} \\
(0.0010)\end{array}$ & $\begin{array}{c}-0.1489^{* * *} \\
(0.0063)\end{array}$ & $\begin{array}{c}-0.0952^{* * *} \\
(0.0087)\end{array}$ & $\begin{array}{l}0.0048^{* *} \\
(0.0459)\end{array}$ & $\begin{array}{c}0.0482^{* * *} \\
(0.0072)\end{array}$ & $\begin{array}{l}-0.0264 \\
(0.1088)\end{array}$ \\
\hline СВРР3 & $\begin{array}{c}0.0226^{* * *} \\
(0.0084)\end{array}$ & $\begin{array}{l}0.1058^{* *} \\
(0.0123)\end{array}$ & $\begin{array}{c}-0.0391+ \\
(0.0864)\end{array}$ & $\begin{array}{c}-0.0223^{* * *} \\
(0.0001)\end{array}$ & $\begin{array}{c}-0.0727^{* * *} \\
(0.0018)\end{array}$ & $\begin{array}{c}-0.1564^{* * *} \\
(0.0005)\end{array}$ \\
\hline TLTRO1_1 & $\begin{array}{c}-0.0148 \\
(0.1190)\end{array}$ & $\begin{array}{l}-0.0359 \\
(0.3199)\end{array}$ & $\begin{array}{c}-0.0709^{* *} \\
(0.0436)\end{array}$ & $\begin{array}{c}0.0511^{* * *} \\
(0.0000)\end{array}$ & $\begin{array}{c}0.0791^{* * *} \\
(0.0015)\end{array}$ & $\begin{array}{l}0.0338+ \\
(0.0889)\end{array}$ \\
\hline TLTRO1_2 & $\begin{array}{c}-0.0658^{* * *} \\
(0.0003)\end{array}$ & $\begin{array}{c}-0.1782^{* * *} \\
(0.0025)\end{array}$ & $\begin{array}{c}-0.1959^{* * *} \\
(0.0030)\end{array}$ & $\begin{array}{c}0.0226^{* * *} \\
(0.0000)\end{array}$ & $\begin{array}{l}0.0287^{* *} \\
(0.0441)\end{array}$ & $\begin{array}{c}-0.0456^{* *} \\
(0.0138)\end{array}$ \\
\hline PSPP & $\begin{array}{c}-0.0700^{* * *} \\
(0.0000)\end{array}$ & $\begin{array}{c}-0.2860^{* * *} \\
(0.0006)\end{array}$ & $\begin{array}{c}-0.1110^{* * *} \\
(0.0040)\end{array}$ & $\begin{array}{c}-0.0139^{* * *} \\
(0.0003)\end{array}$ & $\begin{array}{c}-0.0943^{* * *} \\
(0.0009)\end{array}$ & $\begin{array}{c}0.0957^{* *} \\
(0.0150)\end{array}$ \\
\hline TLTRO2 & $\begin{array}{c}-0.0531^{* * *} \\
(0.0042)\end{array}$ & $\begin{array}{c}-0.1466^{* *} \\
(0.0142)\end{array}$ & $\begin{array}{c}-0.1859^{* *} \\
(0.0105)\end{array}$ & $\begin{array}{c}0.0065 \\
(0.1468)\end{array}$ & $\begin{array}{c}0.0245 \\
(0.1721)\end{array}$ & $\begin{array}{c}0.1346^{* * *} \\
(0.0038)\end{array}$ \\
\hline UK Monetary Policy I & & & & & & \\
\hline APF1_2 & $\begin{array}{l}0.0417^{* *} \\
(0.0225)\end{array}$ & $\begin{array}{l}-0.0228 \\
(0.5266)\end{array}$ & $\begin{array}{l}0.1908^{* *} \\
(0.0315)\end{array}$ & $\begin{array}{c}0.0167^{* * *} \\
(0.0057)\end{array}$ & $\begin{array}{c}-0.1311^{* * *} \\
(0.0014)\end{array}$ & $\begin{array}{l}-0.0096 \\
(0.6412)\end{array}$ \\
\hline
\end{tabular}




\begin{tabular}{|c|c|c|c|c|c|c|}
\hline APF1_3 & $\begin{array}{c}0.1131^{* * *} \\
(0.0003)\end{array}$ & $\begin{array}{c}0.1757^{* * *} \\
(0.0091)\end{array}$ & $\begin{array}{c}0.3154^{* * *} \\
(0.0096)\end{array}$ & $\begin{array}{c}0.0201^{* * *} \\
(0.0013)\end{array}$ & $\begin{array}{l}0.0621^{* *} \\
(0.0195)\end{array}$ & $\begin{array}{l}0.0703^{* *} \\
(0.0290)\end{array}$ \\
\hline APF2_2 & $\begin{array}{c}0.0542^{* * *} \\
(0.0007)\end{array}$ & $\begin{array}{c}0.1783^{* * *} \\
(0.0026)\end{array}$ & $\begin{array}{c}0.1778^{* * *} \\
(0.0046)\end{array}$ & $\begin{array}{c}0.0159^{* * *} \\
(0.0004)\end{array}$ & $\begin{array}{c}0.1054^{* * *} \\
(0.0003)\end{array}$ & $\begin{array}{c}-0.0375^{* *} \\
(0.0395)\end{array}$ \\
\hline APF2_3 & $\begin{array}{c}0.1377^{* * *} \\
(0.0000)\end{array}$ & $\begin{array}{c}0.6668^{* * *} \\
(0.0000)\end{array}$ & $\begin{array}{c}0.4321^{* * *} \\
(0.0002)\end{array}$ & $\begin{array}{c}-0.0080^{* *} \\
(0.0419)\end{array}$ & $\begin{array}{c}0.0165 \\
(0.2109)\end{array}$ & $\begin{array}{l}-0.0233 \\
(0.1948)\end{array}$ \\
\hline TFS & $\begin{array}{l}0.0239+ \\
(0.0669)\end{array}$ & $\begin{array}{c}0.1385^{* *} \\
(0.0317)\end{array}$ & $\begin{array}{c}0.1532^{* * *} \\
(0.0081)\end{array}$ & $\begin{array}{c}0.0131^{* * *} \\
(0.0056)\end{array}$ & $\begin{array}{c}0.0877^{* * *} \\
(0.0032)\end{array}$ & $\begin{array}{c}0.1095^{* * *} \\
(0.0051)\end{array}$ \\
\hline \multicolumn{7}{|l|}{ Pull and Push Factors } \\
\hline FX-Growth-Ratet-1 & $\begin{array}{c}-0.0122^{* *} \\
(0.0133)\end{array}$ & $\begin{array}{c}-0.0198^{* *} \\
(0.0174)\end{array}$ & $\begin{array}{c}-0.0392^{* *} \\
(0.0253)\end{array}$ & $\begin{array}{c}-0.0058^{* *} \\
(0.0107)\end{array}$ & $\begin{array}{c}-0.0146^{* * *} \\
(0.0042)\end{array}$ & $\begin{array}{c}-0.0306^{* * *} \\
(0.0057)\end{array}$ \\
\hline Interest-Rate-Difft-1 & $\begin{array}{l}0.0065^{* *} \\
(0.0215)\end{array}$ & $\begin{array}{l}0.0095^{* *} \\
(0.0379)\end{array}$ & $\begin{array}{c}-0.0537^{* *} \\
(0.0179)\end{array}$ & & & \\
\hline Stocks Returnst-1 & & & & $\begin{array}{c}0.5574^{* * *} \\
(0.0000)\end{array}$ & $\begin{array}{c}2.2579^{* * *} \\
(0.0003)\end{array}$ & $\begin{array}{c}3.4571^{* * *} \\
(0.0022)\end{array}$ \\
\hline $\mathrm{VIX}_{\mathrm{t}-1}$ & $\begin{array}{c}0.0024+ \\
(0.0850)\end{array}$ & $\begin{array}{c}0.0050 \\
(0.1622)\end{array}$ & $\begin{array}{l}0.0110+ \\
(0.0678)\end{array}$ & $\begin{array}{l}-0.0000 \\
(0.9893)\end{array}$ & $\begin{array}{l}-0.0001 \\
(0.9694)\end{array}$ & $\begin{array}{c}-0.0037+ \\
(0.0683)\end{array}$ \\
\hline Oil-Pricest-1 & $\begin{array}{l}0.0030^{* *} \\
(0.0295)\end{array}$ & $\begin{array}{c}0.0090+ \\
(0.0798)\end{array}$ & $\begin{array}{c}0.0060 \\
(0.1327)\end{array}$ & $\begin{array}{l}0.0009^{* *} \\
(0.0263)\end{array}$ & $\begin{array}{l}0.0040^{* *} \\
(0.0455)\end{array}$ & $\begin{array}{c}0.0035 \\
(0.1569)\end{array}$ \\
\hline Observations & 3017 & 2113 & 2150 & 3017 & 2113 & 2150 \\
\hline Countries & 7 & 5 & 5 & 7 & 5 & 5 \\
\hline
\end{tabular}

Fixed effects included but not reported. Driscoll and Kraay (1998) robust standard errors correcting for serial correlation, heteroscedasticity, and cross-section dependence in parenthesis. P-values in parenthesis, + significant at $10 \% ; * *$ significant at $5 \% ; * * *$ significant at $1 \%$.

Now, EA investors' response to US monetary policy measures was qualitatively like that of US investors. In most cases, EA bond and equity flows increased after the announcement of expansionary measures and fell after contractionary measures. The few differences observed are: First, a fall in bond and equity flows from EA to E-Europe and Latam after FG_1 and OT_1, respectively. Second, an increase in bond and equity flows after the fourth rate hike. Concerning the response to UK UMPs, the results highlight a mostly positive response from EA bond and equity investors to these measures which, as seen before, is significantly different from that of UK investors (see Table 5).

Table 5. Effects of Advanced Economies Monetary Policy Measures in EA Portfolio Flows to EMEs

\begin{tabular}{c|ccc|ccc}
\hline & \multicolumn{3}{|c}{ Bonds } & \multicolumn{3}{c}{ Equity } \\
& E-Asia & E-Europe & Latam & E-Asia & E-Europe & Latam \\
\hline US Expansionary Measures & & & & & & \\
QE2_1 & $0.0361^{* * *}$ & 0.0341 & $0.0599^{* *}$ & $0.0024^{* *}$ & 0.0025 & $0.0102^{* *}$ \\
& $(0.0003)$ & $(0.1303)$ & $(0.0427)$ & $(0.0118)$ & $(0.6591)$ & $(0.0338)$ \\
QE2_2 & & & & & & \\
& $0.0451^{* * *}$ & $0.0915^{* *}$ & $0.1038^{* *}$ & $0.0058^{* * *}$ & $0.0295^{* *}$ & 0.0061 \\
& $(0.0004)$ & $(0.0180)$ & $(0.0143)$ & $(0.0008)$ & $(0.0101)$ & $(0.2192)$ \\
QE2_3 & & & & & & \\
& $0.0270^{* * *}$ & $0.0931^{* *}$ & $0.1302^{* * *}$ & $0.0201^{* * *}$ & $0.0527^{* * *}$ & $0.0513^{* * *}$ \\
& $(0.0013)$ & $(0.0102)$ & $(0.0017)$ & $(0.0000)$ & $(0.0002)$ & $(0.0001)$ \\
QE2_4 & & & & & & \\
& $0.0543^{* * *}$ & $0.1427^{* * *}$ & $0.1963^{* * *}$ & $0.0061^{* * *}$ & $0.0700^{* * *}$ & $0.0625^{* * *}$ \\
\hline
\end{tabular}




\begin{tabular}{|c|c|c|c|c|c|c|}
\hline & $(0.0000)$ & $(0.0009)$ & $(0.0003)$ & $(0.0000)$ & $(0.0000)$ & $(0.0000)$ \\
\hline QE2_5 & $\begin{array}{c}0.0227^{* * *} \\
(0.0027)\end{array}$ & $\begin{array}{l}0.0677^{* *} \\
(0.0154)\end{array}$ & $\begin{array}{l}0.0880^{* *} \\
(0.0106)\end{array}$ & $\begin{array}{c}0.0050^{* * *} \\
(0.0001)\end{array}$ & $\begin{array}{c}0.0250^{* * *} \\
(0.0031)\end{array}$ & $\begin{array}{c}0.0374^{* * *} \\
(0.0002)\end{array}$ \\
\hline OT_1 & $\begin{array}{c}-0.1387^{* * *} \\
(0.0000)\end{array}$ & $\begin{array}{c}-0.5751^{* * *} \\
(0.0001)\end{array}$ & $\begin{array}{c}-0.5667^{* * *} \\
(0.0001)\end{array}$ & $\begin{array}{c}-0.0148^{* * *} \\
(0.0002)\end{array}$ & $\begin{array}{c}-0.0607^{* * *} \\
(0.0092)\end{array}$ & $\begin{array}{c}-0.0447^{* *} \\
(0.0154)\end{array}$ \\
\hline OT_2 & $\begin{array}{c}0.0381^{* * *} \\
(0.0000)\end{array}$ & $\begin{array}{c}0.1405^{* * *} \\
(0.0009)\end{array}$ & $\begin{array}{c}0.0960^{* * *} \\
(0.0024)\end{array}$ & $\begin{array}{c}-0.0041^{* * *} \\
(0.0002)\end{array}$ & $\begin{array}{c}-0.0238^{* * *} \\
(0.0032)\end{array}$ & $\begin{array}{l}0.0124^{* *} \\
(0.0168)\end{array}$ \\
\hline FG_1 & $\begin{array}{c}-0.0732^{* * *} \\
(0.0012)\end{array}$ & $\begin{array}{c}-0.2881^{* * *} \\
(0.0055)\end{array}$ & $\begin{array}{c}-0.3790^{* * *} \\
(0.0016)\end{array}$ & $\begin{array}{l}-0.0011 \\
(0.6498)\end{array}$ & $\begin{array}{c}-0.0898^{* * *} \\
(0.0035)\end{array}$ & $\begin{array}{c}-0.0336^{* *} \\
(0.0347)\end{array}$ \\
\hline FG_2 & $\begin{array}{c}0.0362^{* * *} \\
(0.0002)\end{array}$ & $\begin{array}{c}0.0095 \\
(0.6473)\end{array}$ & $\begin{array}{l}0.0501^{* *} \\
(0.0260)\end{array}$ & $\begin{array}{c}0.0081^{* * *} \\
(0.0000)\end{array}$ & $\begin{array}{c}0.0533^{* * *} \\
(0.0003)\end{array}$ & $\begin{array}{c}0.0508^{* * *} \\
(0.0001)\end{array}$ \\
\hline QE3_1 & $\begin{array}{c}-0.0087^{* *} \\
(0.0309)\end{array}$ & $\begin{array}{c}-0.0547^{* *} \\
(0.0263)\end{array}$ & $\begin{array}{c}-0.0303^{* *} \\
(0.0498)\end{array}$ & $\begin{array}{l}0.0011+ \\
(0.0740)\end{array}$ & $\begin{array}{c}0.0225^{* * *} \\
(0.0053)\end{array}$ & $\begin{array}{c}0.0281^{* * *} \\
(0.0016)\end{array}$ \\
\hline QE3_2 & $\begin{array}{c}0.0139^{* * *} \\
(0.0059)\end{array}$ & $\begin{array}{c}0.0253 \\
(0.2021)\end{array}$ & $\begin{array}{c}0.0209 \\
(0.1590)\end{array}$ & $\begin{array}{c}0.0078^{* * *} \\
(0.0000)\end{array}$ & $\begin{array}{c}0.0538^{* * *} \\
(0.0001)\end{array}$ & $\begin{array}{c}0.0361^{* * *} \\
(0.0005)\end{array}$ \\
\hline \multicolumn{7}{|c|}{ US Contractionary Measures } \\
\hline Taper_1 & $\begin{array}{c}-0.0449^{* * *} \\
(0.0000)\end{array}$ & $\begin{array}{c}-0.2767^{* * *} \\
(0.0001)\end{array}$ & $\begin{array}{c}-0.0581^{* * *} \\
(0.0088)\end{array}$ & $\begin{array}{c}-0.0056^{* * *} \\
(0.0001)\end{array}$ & $\begin{array}{c}-0.0448^{* * *} \\
(0.0002)\end{array}$ & $\begin{array}{c}-0.0342^{* * *} \\
(0.0010)\end{array}$ \\
\hline Taper_2 & $\begin{array}{c}-0.1359^{* * *} \\
(0.0000)\end{array}$ & $\begin{array}{c}-0.5836^{* * *} \\
(0.0000)\end{array}$ & $\begin{array}{c}-0.1738^{* * *} \\
(0.0002)\end{array}$ & $\begin{array}{c}-0.0133^{* * *} \\
(0.0000)\end{array}$ & $\begin{array}{c}-0.0468^{* * *} \\
(0.0010)\end{array}$ & $\begin{array}{c}-0.0814^{* * *} \\
(0.0002)\end{array}$ \\
\hline Norm_1 & $\begin{array}{c}-0.0111+ \\
(0.0782)\end{array}$ & $\begin{array}{c}-0.0378 \\
(0.1892)\end{array}$ & $\begin{array}{l}-0.0189 \\
(0.3914)\end{array}$ & $\begin{array}{c}0.0037^{* * *} \\
(0.0036)\end{array}$ & $\begin{array}{c}-0.0008 \\
(0.8784)\end{array}$ & $\begin{array}{c}0.0201^{* * *} \\
(0.0090)\end{array}$ \\
\hline Norm_2 & $\begin{array}{c}-0.0550^{* * *} \\
(0.0000)\end{array}$ & $\begin{array}{c}-0.2760^{* * *} \\
(0.0001)\end{array}$ & $\begin{array}{c}-0.1584^{* * *} \\
(0.0004)\end{array}$ & $\begin{array}{c}-0.0094^{* * *} \\
(0.0000)\end{array}$ & $\begin{array}{c}-0.0513^{* * *} \\
(0.0002)\end{array}$ & $\begin{array}{c}-0.0827^{* * *} \\
(0.0000)\end{array}$ \\
\hline Norm_3 & $\begin{array}{c}0.0311^{* * *} \\
(0.0038)\end{array}$ & $\begin{array}{c}0.1762^{* * *} \\
(0.0048)\end{array}$ & $\begin{array}{c}0.1208^{* * *} \\
(0.0089)\end{array}$ & $\begin{array}{c}0.0057^{* * *} \\
(0.0005)\end{array}$ & $\begin{array}{c}0.0450^{* * *} \\
(0.0013)\end{array}$ & $\begin{array}{c}0.0418^{* * *} \\
(0.0013)\end{array}$ \\
\hline Norm_4 & $\begin{array}{c}0.0226^{* * *} \\
(0.0033)\end{array}$ & $\begin{array}{c}0.1129^{* * *} \\
(0.0078)\end{array}$ & $\begin{array}{c}0.0837^{* * *} \\
(0.0083)\end{array}$ & $\begin{array}{c}0.0028^{* * *} \\
(0.0068)\end{array}$ & $\begin{array}{l}0.0167^{* *} \\
(0.0251)\end{array}$ & $\begin{array}{c}0.0367^{* * *} \\
(0.0009)\end{array}$ \\
\hline \multicolumn{7}{|c|}{ EA Monetary Policy Measures } \\
\hline CBPP2_1 & $\begin{array}{c}-0.0294+ \\
(0.0712)\end{array}$ & $\begin{array}{l}-0.0324 \\
(0.5453)\end{array}$ & $\begin{array}{c}-0.1229+ \\
(0.0913)\end{array}$ & $\begin{array}{c}-0.0090^{* * *} \\
(0.0053)\end{array}$ & $\begin{array}{c}-0.0946^{* * *} \\
(0.0030)\end{array}$ & $\begin{array}{c}-0.0884^{* * *} \\
(0.0008)\end{array}$ \\
\hline CBPP2_2 & $\begin{array}{c}0.0041 \\
(0.6859)\end{array}$ & $\begin{array}{l}0.0677+ \\
(0.0971)\end{array}$ & $\begin{array}{l}-0.0014 \\
(0.9725)\end{array}$ & $\begin{array}{c}0.0053^{* * *} \\
(0.0051)\end{array}$ & $\begin{array}{c}0.0096 \\
(0.3559)\end{array}$ & $\begin{array}{c}-0.0150+ \\
(0.0704)\end{array}$ \\
\hline FG_EA & $\begin{array}{c}-0.0231^{* * *} \\
(0.0016)\end{array}$ & $\begin{array}{c}-0.0866^{* * *} \\
(0.0067)\end{array}$ & $\begin{array}{c}-0.0777^{* * *} \\
(0.0084)\end{array}$ & $\begin{array}{c}-0.0094^{* * *} \\
(0.0000)\end{array}$ & $\begin{array}{c}-0.0467^{* * *} \\
(0.0002)\end{array}$ & $\begin{array}{c}-0.0370^{* * *} \\
(0.0012)\end{array}$ \\
\hline PQE & $\begin{array}{c}0.0287^{* * *} \\
(0.0001)\end{array}$ & $\begin{array}{l}0.0532^{* *} \\
(0.0247)\end{array}$ & $\begin{array}{l}-0.0068 \\
(0.4963)\end{array}$ & $\begin{array}{l}0.0012+ \\
(0.0638)\end{array}$ & $\begin{array}{c}0.0058 \\
(0.1674)\end{array}$ & $\begin{array}{l}0.0110^{* *} \\
(0.0244)\end{array}$ \\
\hline СВРP3 & $\begin{array}{c}0.0068+ \\
(0.0909)\end{array}$ & $\begin{array}{l}0.0393^{* *} \\
(0.0462)\end{array}$ & $\begin{array}{l}-0.0055 \\
(0.6346)\end{array}$ & $\begin{array}{c}-0.0024^{* * *} \\
(0.0077)\end{array}$ & $\begin{array}{c}-0.0305^{* * *} \\
(0.0008)\end{array}$ & $\begin{array}{c}-0.0567^{* * *} \\
(0.0001)\end{array}$ \\
\hline
\end{tabular}




\begin{tabular}{|c|c|c|c|c|c|c|}
\hline TLTRO1_1 & $\begin{array}{c}0.0294^{* * *} \\
(0.0002)\end{array}$ & $\begin{array}{c}0.4564^{* * *} \\
(0.0000)\end{array}$ & $\begin{array}{c}0.0029 \\
(0.8010)\end{array}$ & $\begin{array}{c}0.0032^{* * *} \\
(0.0019)\end{array}$ & $\begin{array}{l}0.0153^{* *} \\
(0.0196)\end{array}$ & $\begin{array}{c}0.0058 \\
(0.2101)\end{array}$ \\
\hline TLTRO1_2 & $\begin{array}{c}0.0305^{* * *} \\
(0.0003)\end{array}$ & $\begin{array}{c}0.1782^{* * *} \\
(0.0003)\end{array}$ & $\begin{array}{l}-0.0145 \\
(0.3845)\end{array}$ & $\begin{array}{c}0.0055^{* * *} \\
(0.0001)\end{array}$ & $\begin{array}{l}-0.0040 \\
(0.4085)\end{array}$ & $\begin{array}{l}0.0076^{* *} \\
(0.0453)\end{array}$ \\
\hline PSPP & $\begin{array}{c}0.0054 \\
(0.1235)\end{array}$ & $\begin{array}{l}0.0385+ \\
(0.0620)\end{array}$ & $\begin{array}{l}-0.0152 \\
(0.1636)\end{array}$ & $\begin{array}{c}-0.0019^{* * *} \\
(0.0081)\end{array}$ & $\begin{array}{c}-0.0041 \\
(0.3101)\end{array}$ & $\begin{array}{c}-0.0111+ \\
(0.0883)\end{array}$ \\
\hline TLTRO2 & $\begin{array}{l}0.0224^{* *} \\
(0.0269)\end{array}$ & $\begin{array}{c}0.1326^{* * *} \\
(0.0088)\end{array}$ & $\begin{array}{c}0.0309 \\
(0.3326)\end{array}$ & $\begin{array}{c}-0.0049^{* * *} \\
(0.0019)\end{array}$ & $\begin{array}{c}-0.0501^{* * *} \\
(0.0011)\end{array}$ & $\begin{array}{c}-0.0261^{* *} \\
(0.0136)\end{array}$ \\
\hline \multicolumn{7}{|c|}{ UK Monetary Policy Measures } \\
\hline APF1_2 & $\begin{array}{c}0.0444^{* * *} \\
(0.0014)\end{array}$ & $\begin{array}{l}0.0667+ \\
(0.0618)\end{array}$ & $\begin{array}{c}0.2161^{* * *} \\
(0.0031)\end{array}$ & $\begin{array}{c}0.0050^{* * *} \\
(0.0019)\end{array}$ & $\begin{array}{c}0.0436^{* * *} \\
(0.0030)\end{array}$ & $\begin{array}{c}0.0375^{* * *} \\
(0.0015)\end{array}$ \\
\hline APF1_3 & $\begin{array}{c}0.0119 \\
(0.1438)\end{array}$ & $\begin{array}{l}0.1000^{* *} \\
(0.0157)\end{array}$ & $\begin{array}{c}0.0157 \\
(0.6420)\end{array}$ & $\begin{array}{c}0.0081^{* * *} \\
(0.0003)\end{array}$ & $\begin{array}{c}0.0489^{* * *} \\
(0.0031)\end{array}$ & $\begin{array}{c}0.0247^{* * *} \\
(0.0082)\end{array}$ \\
\hline APF2_2 & $\begin{array}{c}0.0686^{* * *} \\
(0.0000)\end{array}$ & $\begin{array}{c}0.1557^{* * *} \\
(0.0006)\end{array}$ & $\begin{array}{c}0.1745^{* * *} \\
(0.0002)\end{array}$ & $\begin{array}{c}0.0057^{* * *} \\
(0.0000)\end{array}$ & $\begin{array}{c}0.0554^{* * *} \\
(0.0001)\end{array}$ & $\begin{array}{c}0.0386^{* * *} \\
(0.0002)\end{array}$ \\
\hline APF2_3 & $\begin{array}{c}0.0378^{* * *} \\
(0.0005)\end{array}$ & $\begin{array}{c}0.1604^{* * *} \\
(0.0012)\end{array}$ & $\begin{array}{c}0.0941^{* * *} \\
(0.0094)\end{array}$ & $\begin{array}{c}0.0004 \\
(0.5934)\end{array}$ & $\begin{array}{c}-0.0192^{* *} \\
(0.0127)\end{array}$ & $\begin{array}{c}0.0061 \\
(0.2147)\end{array}$ \\
\hline TFS & $\begin{array}{c}0.0051 \\
(0.4299)\end{array}$ & $\begin{array}{c}0.0129 \\
(0.6717)\end{array}$ & $\begin{array}{l}0.0517+ \\
(0.0812)\end{array}$ & $\begin{array}{c}0.0042^{* * *} \\
(0.0014)\end{array}$ & $\begin{array}{c}0.0033 \\
(0.5604)\end{array}$ & $\begin{array}{c}0.0265^{* * *} \\
(0.0038)\end{array}$ \\
\hline \multicolumn{7}{|l|}{ Pull and Push Factors } \\
\hline FX-Growth-Ratet-1 & $\begin{array}{c}-0.0083^{* * *} \\
(0.0043)\end{array}$ & $\begin{array}{c}-0.0203^{* * *} \\
(0.0086)\end{array}$ & $\begin{array}{c}-0.0246^{* * *} \\
(0.0065)\end{array}$ & $\begin{array}{c}-0.0017^{* * *} \\
(0.0026)\end{array}$ & $\begin{array}{c}-0.0043^{* *} \\
(0.0157)\end{array}$ & $\begin{array}{c}-0.0067^{* *} \\
(0.0164)\end{array}$ \\
\hline Interest-Rate-Difft-1 & $\begin{array}{c}-0.0015+ \\
(0.0601)\end{array}$ & $\begin{array}{c}0.0006 \\
(0.7132)\end{array}$ & $\begin{array}{c}-0.0116+ \\
(0.0961)\end{array}$ & & & \\
\hline Stocks Returnst-1 & & & & $\begin{array}{c}0.0733^{* * *} \\
(0.0010)\end{array}$ & $\begin{array}{c}0.4332^{* * *} \\
(0.0044)\end{array}$ & $\begin{array}{c}0.5483^{* * *} \\
(0.0059)\end{array}$ \\
\hline $\mathrm{VIX}_{\mathrm{t}-1}$ & $\begin{array}{l}-0.0002 \\
(0.6692)\end{array}$ & $\begin{array}{c}-0.0045+ \\
(0.0857)\end{array}$ & $\begin{array}{c}0.0004 \\
(0.8567)\end{array}$ & $\begin{array}{c}-0.0002+ \\
(0.0578)\end{array}$ & $\begin{array}{l}-0.0010 \\
(0.1877)\end{array}$ & $\begin{array}{c}-0.0009+ \\
(0.0773)\end{array}$ \\
\hline Oil-Pricest-1 & $\begin{array}{c}0.0002 \\
(0.7760)\end{array}$ & $\begin{array}{c}0.0001 \\
(0.9664)\end{array}$ & $\begin{array}{l}-0.0004 \\
(0.8933)\end{array}$ & $\begin{array}{c}0.0001 \\
(0.1619)\end{array}$ & $\begin{array}{l}0.0011+ \\
(0.0912)\end{array}$ & $\begin{array}{c}0.0006 \\
(0.2781)\end{array}$ \\
\hline Observations & 3017 & 2113 & 2150 & 3017 & 2113 & 2150 \\
\hline Countries & 7 & 5 & 5 & 7 & 5 & 5 \\
\hline
\end{tabular}

Fixed effects included but not reported. Driscoll and Kraay (1998) robust standard errors correcting for serial correlation, heteroscedasticity, and cross-section dependence in parenthesis. P-values in parenthesis, + significant at $10 \%$;* significant at $5 \%$; *** significant at $1 \%$.

In the case of UK investors' response to US monetary policy, the results are similar to those of EA investors except a fall in bond flows after the first Operation Twist announcement; and an increase in bond flows to E-Asia and E-Europe after the first taper announcement. Finally, after the first rate hike equity flows to E-Asia and E-Europe increased whilst those to all regions rose after the fourth rate increase (see Table 6). In turn, UK bond and equity investors reacted negatively to most of EA policy announcements, excluding an increase in equity flows to E-Europe and Latam after the second TLTRO (see Table 6). 
It is noticeable that bond (equity) investors from all source countries in the analysis responded practically in the same way to US monetary policy events, with only a very few differences. Apart from this, some fewer general cases were the analogous response of US and EA bond (equity) investors to UK monetary policy and the similarities between US and EA equity investors to EA policies.

The substantial similarities in investors' response to US monetary policy can be the result of herding motivated by the strong influence that this country exerts in the global economy and EMEs. However, it is not clear the weight that EA and UK policies have in investors' decisions. For instance, the surprisingly different response of UK investors from that of US and EA ones to UK policies could have been the result of self-imposed regional investment constraints by the firsts; i.e., it may have been that after the financial crisis mutual funds domiciled in the UK decided to change their geographical investment mandate to minimize risk leading to a reduction in investment to EMEs, while US and EA investors did not change their mandate. Of course, this may have not been the only factor affecting UK investors' decision to pull out from EMEs as mentioned above the economic and financial environment in which these policies were announced could have also played an important role.

Regarding the differences in the magnitude of investors' responses to the monetary policy events described above, the results show that these were stronger in E-Europe and Latam; i.e. the estimated parameters are bigger, in absolute value, for these two regions than for E-Asia in most of the cases. One possible explanation is that, as seen in Figures 5 and 6, E-Asia has received more inflows (excluding the dynamics of equity flows from the UK which has been negative since the second half of 2015). This could suggest that investors, at least those tracked by EPFR, consider that such economies could be less affected by monetary policy events than E-Europe and Latam. Lastly, the results also indicate that investors' responses to US monetary policy announcements were bigger than those to EA and UK policies. As mentioned above this may have been the result of the high influence of the US on international financial markets and the global economy in general.

Table 6. Effects of Advanced Economies Monetary Policy Measures in UK Portfolio Flows to EMEs

\begin{tabular}{|c|c|c|c|c|c|c|}
\hline & \multicolumn{3}{|c|}{ Bonds } & \multicolumn{3}{|c|}{ Equity } \\
\hline & E-Asia & E-Europe & Latam & E-Asia & E-Europe & Latam \\
\hline $\begin{array}{l}\text { US Expansionary Measures } \\
\text { QE2_1 }\end{array}$ & $\begin{array}{l}0.0036+ \\
(0.0876)\end{array}$ & $\begin{array}{c}0.0108 \\
(0.1360)\end{array}$ & $\begin{array}{c}0.0073 \\
(0.4117)\end{array}$ & $\begin{array}{l}0.0004^{* *} \\
(0.0429)\end{array}$ & $\begin{array}{c}0.0002 \\
(0.6635)\end{array}$ & $\begin{array}{c}0.0002 \\
(0.7387)\end{array}$ \\
\hline QE2_2 & $\begin{array}{l}0.0445^{* * *} \\
(0.0000)\end{array}$ & $\begin{array}{l}0.1623^{* * *} \\
(0.0000)\end{array}$ & $\begin{array}{l}0.2046^{* * *} \\
(0.0000)\end{array}$ & $\begin{array}{c}0.0020^{* * *} \\
(0.0000)\end{array}$ & $\begin{array}{l}-0.0005 \\
(0.4222)\end{array}$ & $\begin{array}{c}0.0007 \\
(0.4041)\end{array}$ \\
\hline QE2_3 & $\begin{array}{l}0.0396^{* * *} \\
(0.0000)\end{array}$ & $\begin{array}{l}0.1415^{* * *} \\
(0.0000)\end{array}$ & $\begin{array}{l}0.1798^{* * *} \\
(0.0000)\end{array}$ & $\begin{array}{l}-0.0004+ \\
(0.0782)\end{array}$ & $\begin{array}{l}0.0012+ \\
(0.0790)\end{array}$ & $\begin{array}{c}0.0007 \\
(0.3295)\end{array}$ \\
\hline QE2_4 & $\begin{array}{l}0.0133^{* * *} \\
(0.0001)\end{array}$ & $\begin{array}{l}0.0489^{* * *} \\
(0.0008)\end{array}$ & $\begin{array}{c}0.0482^{* * *} \\
(0.0015)\end{array}$ & $\begin{array}{c}0.0012^{* * *} \\
(0.0002)\end{array}$ & $\begin{array}{c}0.0075^{* * *} \\
(0.0001)\end{array}$ & $\begin{array}{l}0.0075^{* * *} \\
(0.0001)\end{array}$ \\
\hline QE2_5 & $\begin{array}{c}0.0003 \\
(0.8713)\end{array}$ & $\begin{array}{c}0.0050 \\
(0.4007)\end{array}$ & $\begin{array}{l}-0.0027 \\
(0.6982)\end{array}$ & $\begin{array}{l}0.0018^{* * *} \\
(0.0000)\end{array}$ & $\begin{array}{c}0.0103^{* * *} \\
(0.0000)\end{array}$ & $\begin{array}{c}0.0088^{* * *} \\
(0.0001)\end{array}$ \\
\hline OT_1 & $\begin{array}{c}-0.0070+ \\
(0.0510)\end{array}$ & $\begin{array}{c}-0.0223+ \\
(0.0931)\end{array}$ & $\begin{array}{c}-0.0343+ \\
(0.0573)\end{array}$ & $\begin{array}{c}0.0006 \\
(0.2464)\end{array}$ & $\begin{array}{c}0.0018 \\
(0.1548)\end{array}$ & $\begin{array}{c}0.0037+ \\
(0.0712)\end{array}$ \\
\hline OT_2 & $\begin{array}{l}-0.0020 \\
(0.2130)\end{array}$ & $\begin{array}{l}-0.0050 \\
(0.4075)\end{array}$ & $\begin{array}{c}-0.0133+ \\
(0.0676)\end{array}$ & $\begin{array}{c}-0.0017^{* * *} \\
(0.0000)\end{array}$ & $\begin{array}{c}0.0001 \\
(0.8982)\end{array}$ & $\begin{array}{c}-0.0026^{* *} \\
(0.0119)\end{array}$ \\
\hline FG_1 & $\begin{array}{c}0.0103+ \\
(0.0628)\end{array}$ & $\begin{array}{l}0.0531^{* *} \\
(0.0310)\end{array}$ & $\begin{array}{c}0.0356 \\
(0.1105)\end{array}$ & $\begin{array}{c}0.0026^{* * *} \\
(0.0019)\end{array}$ & $\begin{array}{c}0.0114^{* * *} \\
(0.0009)\end{array}$ & $\begin{array}{c}0.0051+ \\
(0.0638)\end{array}$ \\
\hline
\end{tabular}




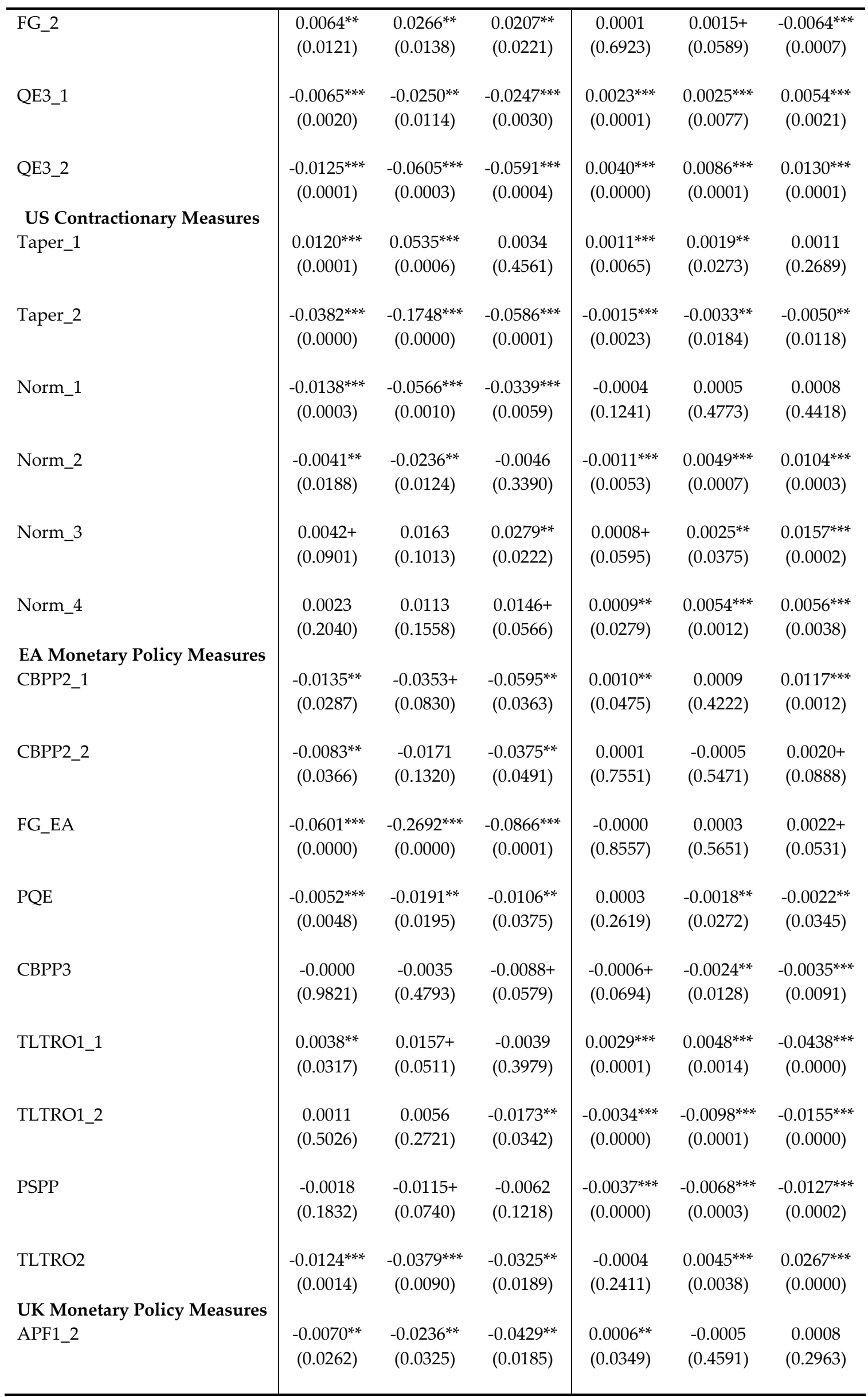




\begin{tabular}{|c|c|c|c|c|c|c|}
\hline APF1_3 & $\begin{array}{c}-0.0135^{* * *} \\
(0.0012)\end{array}$ & $\begin{array}{c}-0.0350^{* * *} \\
(0.0094)\end{array}$ & $\begin{array}{c}-0.0856^{* * *} \\
(0.0018)\end{array}$ & $\begin{array}{c}-0.0006^{* *} \\
(0.0224)\end{array}$ & $\begin{array}{c}-0.0009 \\
(0.1828)\end{array}$ & $\begin{array}{c}-0.0005 \\
(0.5775)\end{array}$ \\
\hline APF2_2 & $\begin{array}{c}0.0388^{* * *} \\
(0.0000)\end{array}$ & $\begin{array}{c}0.1256^{* * *} \\
(0.0000)\end{array}$ & $\begin{array}{c}0.1302^{* * *} \\
(0.0000)\end{array}$ & $\begin{array}{c}0.0065^{* * *} \\
(0.0000)\end{array}$ & $\begin{array}{c}0.0045^{* * *} \\
(0.0010)\end{array}$ & $\begin{array}{c}0.0036^{* * *} \\
(0.0064)\end{array}$ \\
\hline APF2_3 & $\begin{array}{c}-0.0116^{* * *} \\
(0.0006)\end{array}$ & $\begin{array}{c}-0.0372^{* * *} \\
(0.0036)\end{array}$ & $\begin{array}{c}-0.0387^{* * *} \\
(0.0029)\end{array}$ & $\begin{array}{c}0.0010^{* * *} \\
(0.0078)\end{array}$ & $\begin{array}{c}-0.0076^{* * *} \\
(0.0002)\end{array}$ & $\begin{array}{c}-0.0031^{* *} \\
(0.0127)\end{array}$ \\
\hline TFS & $\begin{array}{c}0.0001 \\
(0.9798)\end{array}$ & $\begin{array}{c}0.0096 \\
(0.2528)\end{array}$ & $\begin{array}{l}0.0216^{* *} \\
(0.0307)\end{array}$ & $\begin{array}{c}-0.0017^{* * *} \\
(0.0019)\end{array}$ & $\begin{array}{c}-0.0046^{* * *} \\
(0.0034)\end{array}$ & $\begin{array}{c}0.0083^{* * *} \\
(0.0015)\end{array}$ \\
\hline \multicolumn{7}{|c|}{ Pull and Push Factors } \\
\hline FX-Growth-Ratet-1 & $\begin{array}{c}-0.0021^{* *} \\
(0.0154)\end{array}$ & $\begin{array}{c}-0.0030+ \\
(0.0722)\end{array}$ & $\begin{array}{c}-0.0050^{* *} \\
(0.0307)\end{array}$ & $\begin{array}{c}-0.0002+ \\
(0.0566)\end{array}$ & $\begin{array}{c}-0.0002 \\
(0.2295)\end{array}$ & $\begin{array}{c}-0.0004 \\
(0.2371)\end{array}$ \\
\hline Interest-Rate-Difft-1 & $\begin{array}{l}0.0006^{* *} \\
(0.0337)\end{array}$ & $\begin{array}{c}0.0005 \\
(0.3453)\end{array}$ & $\begin{array}{c}-0.0085^{* *} \\
(0.0186)\end{array}$ & & & \\
\hline Stocks Returnst-1 & & & & $\begin{array}{c}0.0218^{* * *} \\
(0.0075)\end{array}$ & $\begin{array}{l}0.0545^{* *} \\
(0.0102)\end{array}$ & $\begin{array}{l}0.0484+ \\
(0.0786)\end{array}$ \\
\hline $\mathrm{VIX}_{\mathrm{t}-1}$ & $\begin{array}{c}0.0002 \\
(0.2793)\end{array}$ & $\begin{array}{c}0.0011 \\
(0.2155)\end{array}$ & $\begin{array}{c}0.0008 \\
(0.3709)\end{array}$ & $\begin{array}{c}0.0000 \\
(0.2931)\end{array}$ & $\begin{array}{l}0.0001+ \\
(0.0548)\end{array}$ & $\begin{array}{c}0.0001 \\
(0.2364)\end{array}$ \\
\hline Oil-Pricest-1 & $\begin{array}{l}-0.0020 \\
(0.5494)\end{array}$ & $\begin{array}{c}0.0021 \\
(0.8728)\end{array}$ & $\begin{array}{c}0.0330 \\
(0.1273)\end{array}$ & $\begin{array}{c}0.0000 \\
(0.6548)\end{array}$ & $\begin{array}{c}0.0001 \\
(0.3455)\end{array}$ & $\begin{array}{c}0.0000 \\
(0.8151)\end{array}$ \\
\hline Observations & 3017 & 2113 & 2150 & 3017 & 2113 & 2150 \\
\hline Countries & 7 & 5 & 5 & 7 & 5 & 5 \\
\hline
\end{tabular}

Fixed effects included but not reported. Driscoll and Kraay (1998) robust standard errors correcting for serial correlation, heteroscedasticity, and cross-section dependence in parenthesis. P-values in parenthesis, + significant at $10 \%$; ** significant at $5 \%$; *** significant at $1 \%$.

\subsection{Robustness Tests}

To ensure the robustness of the above results, two additional econometric techniques are used. First, equation 2 is re-estimated using heteroscedasticity robust standard errors only. Second, we use Pesaran and Smith's (1995) mean group estimator to account for slope heterogeneity among countries within each region; note that since this methodology consists of estimating individual equations and computing the mean of the estimated slopes, the estimated parameters could be affected by outliers. To correct for it, we use Hamilton's (1992) robust regression.

In general, the results are quite robust to either of the above specifications. The use of heteroscedasticity robust standard errors only affected the significance of a few parameters but no change in signs was observed (see Tables C1 to C3 in Appendix C). The results using the mean group estimator were mostly in line with the initial ones, except for the differences in the magnitude of the parameters (see Tables C4 to C6 in Appendix C). However, this is expected given the different assumptions respect to the other methodologies.7

\section{Conclusion}

This work contributes to the capital flows literature by analyzing whether the monetary policy in advanced economies had differentiated effects on portfolio flows to emerging market economies

\footnotetext{
7 The mean group estimator assumes that the slopes are different across individuals in the panel, whereas in a fixed effects model the assumption is that all individuals have the same slopes (see Pesaran and Smith (1995)).
} 
(classified in three regions: Emerging Asia, Emerging Europe, and Latin America). The analysis is performed by estimating the response of bond and equity flows from the US, EA, and the UK to monetary policy events in these same countries.

The results show that US monetary policy events led investors from the US, the EA, and the UK to react in the same way. For example, events related to the second quantitative easing program motivated an increase of bonds (equity) flows to all emerging regions, whilst the taper tantrum made all investors withdraw resources from all regions. The only difference in the response of investors to US policies was the amount entered or withdrawn in each group. For instance, a percentage of assets under management, Emerging Europe, and Latin America saw bigger movements of capital relative to those seen in Emerging Asia. One possible reason for investors' similar response to US monetary policy is herding, which according to the literature usually plays an important role explaining analogous investment decisions; i.e. given the strong influence that the US has globally, it is not surprising that its policies significantly motivate investors to follow each other closely.

In turn, investors' responses to monetary policy events in other advanced economies (EA and UK) were mixed: In one side, US and EA bond investors' responses to UK policies were practically similar as it was the case with that of US and EA equity investors to EA and UK policies. On the other, the responses of US, EA, and UK bond investors, as well as those of UK equity investors, to EA polices were mostly different.

Surprisingly, the responses of UK bond and equity investors to UK policies were significantly different from those of US and EA ones. This work posits as one possible explanation the timing in which these policies were announced and the elevated volatility in financial markets after the crises, which could have motivated UK investors to change their geographical investment mandate and reduce flows to EMEs. Of course, these may not be the only factor affecting UK investors' decision to pull out from EMEs, but finding a definite explanation goes beyond the scope of this article.

Finally, the results show that investors' response to monetary policy events is stronger in EEurope and Latam than in E-Asia; probably because other phenomena such as investors' preferences (in the case of bonds) or particular expectations for firms' profits (in the case of equity) could be relevant for investors' decisions. Besides, US monetary policy had bigger effects on international investors than policies from EA and the UK. These results could be useful for policymakers in EMEs as a benchmark to anticipate differentiated effects in portfolio flows caused by monetary policy in advanced economies.

Funding: This research received no external funding.

Conflicts of Interest: The author declares no conflict of interest. 


\section{Appendix A}

Table A1. Bond and Equity Flows from the US to Emerging Economies In Billions of US Dollars

\begin{tabular}{|c|c|c|c|c|}
\hline Variable & Mean & $\begin{array}{l}\text { Standard } \\
\text { Deviation }\end{array}$ & Min. & Max \\
\hline \multicolumn{5}{|c|}{ Asia } \\
\hline \multicolumn{5}{|c|}{ Equity Inflows } \\
\hline India & 42.02 & 142.89 & -595.37 & 836.87 \\
\hline Indonesia & 11.57 & 45.42 & -262.03 & 164.15 \\
\hline Israel & 2.58 & 16.74 & -87.22 & 115.31 \\
\hline Korea & 7.43 & 13.15 & -73.63 & 59.51 \\
\hline Malaysia & 45.32 & 160.18 & -662.77 & 717.77 \\
\hline Philippines & 5.16 & 32.44 & -178.54 & 133.14 \\
\hline Thailand & 15.76 & 92.64 & -324.55 & 518.32 \\
\hline \multicolumn{5}{|l|}{ Bond Inflows } \\
\hline India & 0.82 & 4.76 & -19.91 & 23.91 \\
\hline Indonesia & 7.46 & 20.59 & -86.81 & 108.03 \\
\hline Israel & 2.97 & 8.73 & -32.64 & 40.33 \\
\hline Korea & 0.48 & 1.90 & -9.03 & 10.92 \\
\hline Malaysia & 4.01 & 9.33 & -48.25 & 42.89 \\
\hline Philippines & 3.71 & 10.55 & -38.37 & 46.30 \\
\hline Thailand & 11.26 & 30.69 & -102.51 & 140.74 \\
\hline \multicolumn{5}{|c|}{ Emerging Europe } \\
\hline \multicolumn{5}{|c|}{ Equity Inflows } \\
\hline Hungary & 3.25 & 15.97 & -58.89 & 97.69 \\
\hline Poland & 27.05 & 97.52 & -368.27 & 408.60 \\
\hline Russia & 21.98 & 74.81 & -321.16 & 299.04 \\
\hline South Africa & 8.96 & 35.96 & -173.13 & 150.13 \\
\hline Turkey & 8.98 & 44.50 & -218.01 & 181.22 \\
\hline \multicolumn{5}{|l|}{ Bond Inflows } \\
\hline Hungary & 6.04 & 13.86 & -44.95 & 63.13 \\
\hline Poland & 8.16 & 23.15 & -101.76 & 101.83 \\
\hline Russia & 5.28 & 14.46 & -52.92 & 63.37 \\
\hline South Africa & 4.98 & 17.15 & -64.76 & 88.58 \\
\hline Turkey & 1.08 & 5.50 & -22.01 & 27.93 \\
\hline \multicolumn{5}{|c|}{ Latin America } \\
\hline \multicolumn{5}{|c|}{ Equity Inflows } \\
\hline Brazil & 37.75 & 215.23 & -817.68 & $1,364.45$ \\
\hline Chile & 3.55 & 20.50 & -65.03 & 108.92 \\
\hline Colombia & 1.53 & 7.40 & -26.73 & 41.56 \\
\hline Mexico & 15.78 & 102.34 & -672.16 & 651.29 \\
\hline Peru & 1.63 & 4.74 & -14.28 & 19.15 \\
\hline \multicolumn{5}{|l|}{ Bond Inflows } \\
\hline Brazil & 11.93 & 30.37 & -114.32 & 134.71 \\
\hline Chile & 1.32 & 4.98 & -19.32 & 21.35 \\
\hline Colombia & 3.21 & 12.18 & -52.59 & 62.65 \\
\hline Mexico & 0.49 & 3.14 & -15.25 & 13.97 \\
\hline Peru & 3.28 & 9.00 & -33.75 & 46.88 \\
\hline
\end{tabular}

Source: EPRF. 
Table A2. Bond and Equity Flows from the EA to Emerging Economies In Billions of US Dollars

\begin{tabular}{|c|c|c|c|c|}
\hline Variable & Mean & $\begin{array}{l}\text { Standard } \\
\text { Deviation }\end{array}$ & Min. & $\operatorname{Max}$ \\
\hline \multicolumn{5}{|c|}{ Asia } \\
\hline \multicolumn{5}{|l|}{ Equity Inflows } \\
\hline India & 4.49 & 40.70 & -163.51 & 196.31 \\
\hline Indonesia & 1.17 & 8.46 & -30.74 & 27.30 \\
\hline Israel & 0.22 & 1.75 & -6.35 & 6.15 \\
\hline Korea & 0.53 & 2.87 & -30.65 & 13.30 \\
\hline Malaysia & 3.81 & 48.79 & -240.25 & 240.38 \\
\hline Philippines & 0.50 & 9.46 & -46.13 & 64.24 \\
\hline Thailand & 1.55 & 12.58 & -46.45 & 52.35 \\
\hline \multicolumn{5}{|l|}{ Bond Inflows } \\
\hline India & 1.33 & 4.61 & -26.07 & 27.59 \\
\hline Indonesia & 5.48 & 15.51 & -106.58 & 64.61 \\
\hline Israel & 2.10 & 6.35 & -39.84 & 24.02 \\
\hline Korea & 0.65 & 1.78 & -11.97 & 7.95 \\
\hline Malaysia & 1.84 & 4.95 & -29.49 & 19.47 \\
\hline Philippines & 2.50 & 7.50 & -48.60 & 29.11 \\
\hline Thailand & 7.86 & 21.66 & -122.27 & 83.28 \\
\hline \multicolumn{5}{|c|}{ Emerging Europe } \\
\hline \multicolumn{5}{|l|}{ Equity Inflows } \\
\hline Hungary & -0.93 & 8.58 & -62.61 & 71.20 \\
\hline Poland & -0.56 & 55.21 & -240.44 & 375.24 \\
\hline Russia & 2.14 & 17.44 & -71.54 & 62.25 \\
\hline South Africa & -0.34 & 16.12 & -89.79 & 79.54 \\
\hline Turkey & 1.01 & 11.01 & -33.71 & 139.10 \\
\hline \multicolumn{5}{|l|}{ Bond Inflows } \\
\hline Hungary & 3.37 & 11.42 & -58.39 & 55.92 \\
\hline Poland & 5.36 & 16.98 & -85.82 & 62.35 \\
\hline Russia & 3.35 & 10.25 & -67.07 & 37.90 \\
\hline South Africa & 3.79 & 13.01 & -81.18 & 53.00 \\
\hline Turkey & 1.22 & 4.25 & -28.58 & 17.90 \\
\hline \multicolumn{5}{|c|}{ Latin America } \\
\hline \multicolumn{5}{|l|}{ Equity Inflows } \\
\hline Brazil & 2.78 & 48.49 & -238.41 & 185.75 \\
\hline Chile & 0.40 & 4.04 & -14.14 & 30.19 \\
\hline Colombia & 0.10 & 1.24 & -5.72 & 5.28 \\
\hline Mexico & -2.71 & 23.09 & -103.35 & 105.46 \\
\hline Peru & 0.03 & 2.10 & -9.89 & 9.93 \\
\hline \multicolumn{5}{|l|}{ Bond Inflows } \\
\hline Brazil & 7.70 & 22.01 & -140.04 & 82.65 \\
\hline Chile & 1.06 & 3.57 & -17.68 & 14.27 \\
\hline Colombia & 2.89 & 9.31 & -64.64 & 37.17 \\
\hline Mexico & 0.78 & 2.58 & -12.63 & 14.33 \\
\hline Peru & 1.99 & 7.09 & -40.23 & 30.58 \\
\hline
\end{tabular}

Source: EPRF. 
Table A3. Bond and Equity Flows from the UK to Emerging Economies In Billions of US Dollars

\begin{tabular}{|c|c|c|c|c|}
\hline Variable & Mean & $\begin{array}{l}\text { Standard } \\
\text { Deviation }\end{array}$ & Min. & $\operatorname{Max}$ \\
\hline \multicolumn{5}{|c|}{ Asia } \\
\hline \multicolumn{5}{|l|}{ Equity Inflows } \\
\hline India & -0.86 & 14.43 & -60.25 & 101.97 \\
\hline Indonesia & -0.28 & 3.59 & -11.62 & 13.36 \\
\hline Israel & -0.13 & 1.25 & -6.89 & 12.98 \\
\hline Korea & -2.48 & 18.39 & -76.71 & 55.68 \\
\hline Malaysia & -0.23 & 2.82 & -12.63 & 9.00 \\
\hline Philippines & -0.47 & 2.40 & -11.14 & 6.99 \\
\hline Thailand & -0.43 & 4.51 & -14.90 & 17.97 \\
\hline \multicolumn{5}{|l|}{ Bond Inflows } \\
\hline India & 0.01 & 0.87 & -3.40 & 2.90 \\
\hline Indonesia & 0.51 & 3.47 & -15.17 & 12.05 \\
\hline Israel & 0.22 & 1.70 & -8.78 & 6.63 \\
\hline Korea & 0.01 & 0.44 & -2.70 & 1.58 \\
\hline Malaysia & 0.51 & 2.35 & -9.83 & 7.12 \\
\hline Philippines & 0.22 & 1.82 & -7.82 & 6.42 \\
\hline Thailand & 1.06 & 6.91 & -26.06 & 24.98 \\
\hline \multicolumn{5}{|c|}{ Emerging Europe } \\
\hline \multicolumn{5}{|l|}{ Equity Inflows } \\
\hline Hungary & -0.06 & 0.36 & -2.19 & 1.32 \\
\hline Poland & -0.28 & 1.27 & -11.80 & 6.42 \\
\hline Russia & -1.08 & 6.61 & -34.51 & 23.43 \\
\hline South Africa & 0.10 & 3.95 & -11.54 & 14.24 \\
\hline Turkey & -0.06 & 1.71 & -9.50 & 7.48 \\
\hline \multicolumn{5}{|l|}{ Bond Inflows } \\
\hline Hungary & 0.50 & 3.59 & -14.26 & 13.11 \\
\hline Poland & 0.96 & 4.87 & -29.86 & 24.98 \\
\hline Russia & 0.30 & 2.52 & -11.41 & 8.33 \\
\hline South Africa & 0.35 & 3.16 & -19.95 & 11.31 \\
\hline Turkey & 0.03 & 0.83 & -5.78 & 3.45 \\
\hline \multicolumn{5}{|c|}{ Latin America } \\
\hline \multicolumn{5}{|l|}{ Equity Inflows } \\
\hline Brazil & -0.37 & 8.53 & -51.23 & 45.22 \\
\hline Chile & -0.08 & 0.99 & -7.80 & 8.14 \\
\hline Colombia & -0.02 & 0.43 & -4.03 & 3.70 \\
\hline Mexico & -0.12 & 3.31 & -20.35 & 20.11 \\
\hline Peru & -0.01 & 0.53 & -4.06 & 4.03 \\
\hline \multicolumn{5}{|l|}{ Bond Inflows } \\
\hline Brazil & 1.39 & 6.05 & -27.22 & 23.35 \\
\hline Chile & 0.02 & 1.04 & -6.12 & 3.86 \\
\hline Colombia & 0.21 & 2.14 & -11.51 & 7.87 \\
\hline Mexico & 0.10 & 0.57 & -2.36 & 2.16 \\
\hline Peru & 0.36 & 1.82 & -6.60 & 8.40 \\
\hline
\end{tabular}

Source: EPRF. 
Table A4. Exchange Rates in Local Currency per US Dollar

\begin{tabular}{|c|c|c|c|c|}
\hline Variable & Mean & $\begin{array}{c}\text { Standard } \\
\text { Deviation }\end{array}$ & Min. & Max \\
\hline \multicolumn{5}{|c|}{ Asia } \\
\hline India & 52.26 & 9.09 & 39.29 & 68.61 \\
\hline Indonesia & $10,504.77$ & $1,726.50$ & $8,488.40$ & $14,680.60$ \\
\hline Israel & 3.89 & 0.33 & 3.25 & 4.73 \\
\hline Korea & $1,096.23$ & 104.93 & 907.52 & $1,544.92$ \\
\hline Malaysia & 3.53 & 0.40 & 2.96 & 4.49 \\
\hline Philippines & 46.74 & 4.11 & 40.35 & 56.38 \\
\hline Thailand & 34.07 & 3.06 & 28.75 & 41.89 \\
\hline \multicolumn{5}{|c|}{ Emerging Europe } \\
\hline Hungary & 221.08 & 36.03 & 145.50 & 299.17 \\
\hline Poland & 3.20 & 0.44 & 2.04 & 4.24 \\
\hline Russia & 36.76 & 14.14 & 23.24 & 79.45 \\
\hline South Africa & 9.15 & 2.70 & 5.65 & 16.73 \\
\hline Turkey & 1.91 & 0.68 & 1.16 & 3.81 \\
\hline \multicolumn{5}{|c|}{ Latin America } \\
\hline Brazil & 2.33 & 0.61 & 1.55 & 4.10 \\
\hline Chile & 555.30 & 69.17 & 434.92 & 728.05 \\
\hline Colombia & $2,228.97$ & 424.53 & $1,681.08$ & $3,396.79$ \\
\hline Mexico & 13.32 & 2.62 & 9.94 & 21.69 \\
\hline Peru & 3.02 & 0.26 & 2.55 & 3.52 \\
\hline
\end{tabular}

Source: Bloomberg.

Table A5. Short-Term Interest Rates in Percent

\begin{tabular}{|c|c|c|c|c|}
\hline Variable & Mean & $\begin{array}{l}\text { Standard } \\
\text { Deviation }\end{array}$ & Min. & Max \\
\hline \multicolumn{5}{|c|}{ Asia } \\
\hline India & 7.92 & 1.72 & 4.34 & 12.64 \\
\hline Indonesia & 7.86 & 2.23 & 4.18 & 14.63 \\
\hline Israel & 2.28 & 1.81 & 0.05 & 5.83 \\
\hline Korea & 3.15 & 1.26 & 1.27 & 6.09 \\
\hline Malaysia & 3.27 & 0.46 & 2.11 & 3.92 \\
\hline Philippines & 3.66 & 2.30 & -0.83 & 8.32 \\
\hline Thailand & 2.71 & 1.12 & 1.35 & 5.41 \\
\hline \multicolumn{5}{|c|}{ Emerging Europe } \\
\hline Hungary & 5.41 & 2.98 & 0.03 & 12.28 \\
\hline Poland & 3.80 & 1.54 & 1.55 & 7.06 \\
\hline Russia & 8.77 & 3.94 & 4.35 & 27.10 \\
\hline South Africa & 7.24 & 1.90 & 5.07 & 12.58 \\
\hline Turkey & 12.10 & 4.54 & 4.76 & 24.20 \\
\hline \multicolumn{5}{|c|}{ Latin America } \\
\hline Brazil & 12.15 & 3.10 & 7.11 & 19.76 \\
\hline Chile & 3.97 & 1.72 & 0.37 & 8.29 \\
\hline Colombia & 5.75 & 2.06 & 1.62 & 10.04 \\
\hline Mexico & 5.57 & 1.99 & 2.84 & 10.04 \\
\hline Peru & 4.77 & 1.24 & 1.49 & 7.95 \\
\hline
\end{tabular}

Note: Represented by the 3-month money market or interbank rate.

Source: Bloomberg.

Table A6. Stock Market Indices 


\begin{tabular}{lrrrr}
\hline \multicolumn{1}{c}{ Variable } & Mean & \multicolumn{2}{c}{$\begin{array}{c}\text { Standard } \\
\text { Deviation }\end{array}$} & Min. \\
\hline India & \multicolumn{3}{c}{ Asia } & \\
Indonesia & 9.98 & 0.22 & 9.53 & 10.41 \\
Israel & 8.35 & 0.24 & 7.63 & 8.70 \\
Korea & 8.31 & 0.09 & 7.98 & 8.56 \\
Malaysia & 7.38 & 0.12 & 6.98 & 7.54 \\
Philippines & 8.63 & 0.33 & 7.80 & 9.04 \\
Thailand & 7.11 & 0.26 & 6.35 & 7.45 \\
& 7.17 & 0.14 & 6.75 & 7.45 \\
Hungary & & Emerging Europe & 10.59 \\
Poland & 9.98 & 0.22 & 9.60 & 11.08 \\
Russia & 10.76 & 0.14 & 10.31 & 7.72 \\
South Africa & 7.36 & 0.16 & 6.80 & 11.61 \\
Turkey & 11.16 & 0.20 & 10.52 & 10.87 \\
& 10.49 & 0.25 & 9.87 & 11.25 \\
Brazil & & Latin America & 10.24 \\
Chile & 10.96 & 0.13 & 10.54 & 7.57 \\
Colombia & 9.90 & 0.11 & 9.60 & 10.85 \\
Mexico & 7.32 & 0.14 & 6.97 & 10.07 \\
Peru & 10.60 & 0.15 & 10.01 & \\
\hline
\end{tabular}

Note: All indices are expressed in natural logarithms.

Source: Bloomberg.

Table A7. Foreign Variables or Push Factors

\begin{tabular}{lcrrrr}
\hline \multicolumn{1}{c}{ Variable } & Units & Mean & Standard Deviation & Min. & \multicolumn{1}{c}{ Max } \\
\hline VIX & Index & 17.70 & 5.86 & 9.48 & 41.18 \\
WTI Oil Prices & USD per barrel & 75.67 & 22.82 & 28.84 & 112.39 \\
& \multicolumn{2}{c}{ Short-Term Interest Rates } & & & \\
United States & Percent & 0.26 & 0.27 & 0.07 & 1.22 \\
Euro area & Percent & 0.15 & 0.41 & -0.36 & 1.34 \\
United Kingdom & Percent & 0.62 & 0.19 & 0.28 & 1.14 \\
\hline
\end{tabular}

Note: For the US, the short-term interest rates are represented by the 3-month OIL rate. In the case of the euro area, the 3-month Swap OIS rate was used. For the UK, the 3-month Libor rate was selected. Source: Bloomberg.

Table A8. Panel Unit Root Test - Breitung and Das (2005)

\begin{tabular}{ccccc}
\hline Variable & Statistic & P-value & Cross-sections & Obs. \\
\hline Bonds from US & -10.006 & 0.000 & 17 & 431 \\
Bonds from EA & -15.774 & 0.000 & 17 & 431 \\
Bonds from UK & -11.410 & 0.000 & 17 & 431 \\
& & & & \\
Equity from US & -15.713 & 0.000 & 17 & 431 \\
Equity from EA & -19.842 & 0.000 & 17 & 431 \\
Equity from UK & -11.262 & 0.000 & 17 & 431 \\
\hline
\end{tabular}

Note. The null hypothesis assumes that all panels contain a unit root. 


\section{Appendix B}

Table B1. US Monetary Policy Actions

\begin{tabular}{|c|c|c|c|}
\hline Mnemonic & Explanation & $\begin{array}{c}\text { Statement } \\
\text { Date }\end{array}$ & $\begin{array}{l}\text { Dummy } \\
\text { Date }\end{array}$ \\
\hline QE2_1 & $\begin{array}{l}\text { "To help support economic recovery in the context of price stability, } \\
\text { the Committee will keep the Federal Reserve's holdings of securities } \\
\text { at their current level by reinvesting principal payments from agency } \\
\text { debt and agency mortgage-backed securities in longer-term Treasury } \\
\text { securities. The Committee will continue to roll over the Federal } \\
\text { Reserve's holdings of Treasury securities as they mature." }\end{array}$ & $10 / 08 / 2010$ & $18 / 08 / 2010$ \\
\hline QE2_2 & $\begin{array}{l}\text { Bernanke's speech at Jackson Hole: "The Committee is prepared to } \\
\text { provide additional monetary accommodation through } \\
\text { unconventional measures if it proves necessary, especially if the } \\
\text { outlook were to deteriorate significantly." }\end{array}$ & $27 / 08 / 2010$ & $01 / 09 / 2010$ \\
\hline QE2_3 & $\begin{array}{l}\text { The FOMC statement that indicated the Committee will maintain its } \\
\text { existing policy of reinvesting principal payments from its securities } \\
\text { holdings. }\end{array}$ & $21 / 09 / 2010$ & $29 / 09 / 2010$ \\
\hline QE2_4 & $\begin{array}{l}\text { Bernanke's speech at Boston Fed: "there would appear-all else being } \\
\text { equal-to be a case for further action." }\end{array}$ & $15 / 10 / 2010$ & $20 / 10 / 2010$ \\
\hline QE2_5 & $\begin{array}{l}\text { QE2 announced: "The Committee intends to purchase a further } \$ 600 \\
\text { billion of longer-term Treasury securities by the end of the second } \\
\text { quarter of } 2011 \text {, a pace of about } \$ 75 \text { billion per month." }\end{array}$ & 03/11/2010 & $10 / 11 / 2010$ \\
\hline FG_1 & $\begin{array}{l}\text { "Economic conditions... are likely to warrant exceptionally low levels } \\
\text { for the federal funds rate for at least through mid-2013." }\end{array}$ & 09/08/2011 & $17 / 08 / 2011$ \\
\hline FG_2 & $\begin{array}{l}\text { "Economic conditions... are likely to warrant exceptionally low levels } \\
\text { for the federal funds rate for at least through late 2014." }\end{array}$ & $25 / 01 / 2012$ & $01 / 02 / 2012$ \\
\hline OT_1 & $\begin{array}{l}\text { Operation Twist begins: "To support a stronger economic recovery } \\
\text { and to help ensure that inflation, over time, is at levels consistent with } \\
\text { the dual mandate, the Committee decided today to extend the } \\
\text { average maturity of its holdings of securities. The Committee intends } \\
\text { to purchase, by the end of June } 2012, \$ 400 \text { billion of Treasury } \\
\text { securities with remaining maturities of } 6-30 \text { years and to sell an equal } \\
\text { amount of Treasury securities with remaining maturities of } 3 \text { years or } \\
\text { less." }\end{array}$ & $21 / 09 / 2011$ & $28 / 09 / 2011$ \\
\hline OT_2 & $\begin{array}{l}\text { Operation Twist extended: "The Committee also decided to continue } \\
\text { through the end of the year its program to extend the average } \\
\text { maturity of its holdings of securities." }\end{array}$ & $20 / 06 / 2012$ & $27 / 06 / 2012$ \\
\hline QE3_1 & $\begin{array}{l}\text { QE3 announced: "If the outlook for the labor market does not } \\
\text { improve substantially, the Committee will continue its purchase of } \\
\text { agency MBS, undertake additional asset purchases, and employ its } \\
\text { other policy tools as appropriate." }\end{array}$ & $13 / 09 / 2012$ & $19 / 09 / 2012$ \\
\hline QE3_2 & $\begin{array}{l}\text { "The exceptionally low range for the federal funds rate will be } \\
\text { appropriate at least as long as the unemployment rate remains above } \\
6-1 / 2 \text { percent, inflation between one and two years ahead is projected } \\
\text { to be no more than half percentage point above the Committee's } 2 \\
\text { percent longer-run goal, and longer-term inflation expectations } \\
\text { continue to be well anchored." }\end{array}$ & $12 / 12 / 2012$ & $19 / 12 / 2012$ \\
\hline Taper_1 & $\begin{array}{l}\text { Taper Tantrum by Bernanke: "In the next few meetings, we could take } \\
\text { a step down in our pace of purchase." }\end{array}$ & $22 / 05 / 2013$ & $29 / 05 / 2013$ \\
\hline Taper_2 & $\begin{array}{l}\text { Bernanke's press conference: "If we see continued improvement and } \\
\text { we have confidence that that is going to be sustained, then in the next } \\
\text { few meetings, we could take a step down in our pace of purchase." }\end{array}$ & $19 / 06 / 2013$ & $26 / 06 / 2013$ \\
\hline
\end{tabular}




\begin{tabular}{llll}
\hline Norm_1 & First-rate increase since the Financial Crisis. & $16 / 12 / 2015$ & $23 / 12 / 2015$ \\
Norm_2 & Second-rate increase since the Financial Crisis. & $14 / 12 / 2016$ & $21 / 12 / 2016$ \\
Norm_3 & Third rate increase since the Financial Crisis. & $15 / 03 / 2017$ & $22 / 03 / 2017$ \\
Norm_4 & $\begin{array}{l}\text { Fourth rate increase since the Financial Crisis. FOMC announces a } \\
\text { plan consisting of "reduc[ing] the Federal Reserve's securities } \\
\end{array}$ & $14 / 06 / 2017$ & $21 / 06 / 2017$ \\
& $\begin{array}{l}\text { holdings by decreasing reinvestment of principal payments from } \\
\text { those securities." }\end{array}$ & & \\
\hline
\end{tabular}

Source: Federal Reserve Bank, Bloomberg \& Park, and Um (2016). 
Table B2. EA Monetary Policy Actions

\begin{tabular}{|c|c|c|c|}
\hline Mnemonic & Explanation & $\begin{array}{l}\text { Statement } \\
\text { Date }\end{array}$ & $\begin{array}{l}\text { Dummy } \\
\text { Date }\end{array}$ \\
\hline CBPP2_1 & $\begin{array}{l}\text { ECB announces a new covered bond purchase program, for an } \\
\text { intended amount of } € 40 \text { billion. }\end{array}$ & $06 / 10 / 2011$ & $12 / 10 / 2011$ \\
\hline CBPP2_2 & ECB decides upon the technical modalities of the program. & $03 / 11 / 2011$ & $09 / 11 / 2011$ \\
\hline FG_EA & $\begin{array}{l}\text { Draghi introduces forward guidance for interest rates: "The } \\
\text { Governing Council expects the key ECB interest rates to remain at } \\
\text { present or lower levels for an extended period." }\end{array}$ & $04 / 07 / 2013$ & $10 / 07 / 2013$ \\
\hline PQE & $\begin{array}{l}\text { ECB prepares the groundwork for QE: "The Governing Council is } \\
\text { committed - unanimously - to using both unconventional and } \\
\text { conventional instruments to deal effectively with the risks of a too } \\
\text { prolonged period of low inflation." }\end{array}$ & $24 / 04 / 2014$ & $30 / 04 / 2014$ \\
\hline СВРP3 & $\begin{array}{l}\text { ECB announces program to by asset-backed securities and a broad } \\
\text { portfolio of euro-denominated covered bonds. }\end{array}$ & $02 / 10 / 2014$ & $08 / 10 / 2014$ \\
\hline TLTRO1_1 & $\begin{array}{l}\text { ECB decides to conduct a series of targeted longer-term refinancing } \\
\text { operations, aimed at improving bank lending to the euro area non- } \\
\text { financial private sector, excluding loans to households for house } \\
\text { purchase, over a window of two years. }\end{array}$ & 05/06/2014 & $11 / 06 / 2014$ \\
\hline TLTRO1_2 & $\begin{array}{l}\text { ECB changes the interest rate applicable to future targeted longer- } \\
\text { term refinancing operations to the Eurosystem's main refinancing } \\
\text { operations prevailing at the time when each TLTRO is conducted. }\end{array}$ & $22 / 01 / 2015$ & $28 / 01 / 2015$ \\
\hline PSPP & $\begin{array}{l}\text { ECB begins to buy public sector securities, which include nominal } \\
\text { and inflation-linked central government bonds, and bonds issued by } \\
\text { recognized agencies, regional and local governments, international } \\
\text { organizations, and multilateral development banks located in the } \\
\text { euro area. }\end{array}$ & 09/03/2015 & $11 / 03 / 2015$ \\
\hline TLTRO2 & $\begin{array}{l}\text { ECB announces a new series of targeted longer-term refinancing } \\
\text { operations and adds corporate sector purchase program to existing } \\
\text { programs, as well as announces changes to the asset purchase } \\
\text { program. }\end{array}$ & $10 / 03 / 2016$ & $16 / 03 / 2016$ \\
\hline
\end{tabular}

Source: European Central Bank and Bloomberg. 
Table B3. UK Monetary Policy Actions

\begin{tabular}{|c|c|c|c|}
\hline Mnemonic & Explanation & $\begin{array}{l}\text { Statement } \\
\text { Date }\end{array}$ & $\begin{array}{l}\text { Dummy } \\
\text { Date }\end{array}$ \\
\hline APF1_2 & $\begin{array}{l}\text { BoE increases the scale of its asset purchase program to a total of } £ 175 \\
\text { billion, and the buying range will be extended to GILTs. }\end{array}$ & 06/08/2009 & $12 / 08 / 2009$ \\
\hline APF1_3 & $\begin{array}{l}\text { BoE increases the scale of its asset purchase program to a total of } £ 200 \\
\text { billion. }\end{array}$ & 05/11/2009 & $11 / 11 / 2009$ \\
\hline APF2_1 & $\begin{array}{l}\text { BoE increases the scale of its asset purchase program to a total of } £ 275 \\
\text { billion. }\end{array}$ & $06 / 10 / 2011$ & $12 / 10 / 2011$ \\
\hline APF2_2 & $\begin{array}{l}\text { BoE increases the scale of its asset purchase program to a total of } £ 325 \\
\text { billion. }\end{array}$ & 09/02/2012 & $15 / 02 / 2012$ \\
\hline APF2_3 & $\begin{array}{l}\text { BoE increases the scale of its asset purchase program to a total of } £ 375 \\
\text { billion. }\end{array}$ & 05/07/2012 & $11 / 07 / 2012$ \\
\hline TFS & $\begin{array}{l}\text { BoE introduces a new Term Funding Scheme, the purchase of up to } \\
£ 10 \text { billion of UK corporate bonds; and an expansion of the asset } \\
\text { purchase scheme for UK government bonds of } £ 60 \text { billion, taking the } \\
\text { total stock of these asset purchases to } £ 435 \text { billion. The last three } \\
\text { elements will be financed by the issuance of central bank reserves. }\end{array}$ & $04 / 08 / 2016$ & $10 / 08 / 2016$ \\
\hline
\end{tabular}

Source: Bank of England and Bloomberg. 


\section{Appendix C}

Table C1. Effects of Advanced Economies Monetary Policy Measures in US Portfolio Flows to EMEs

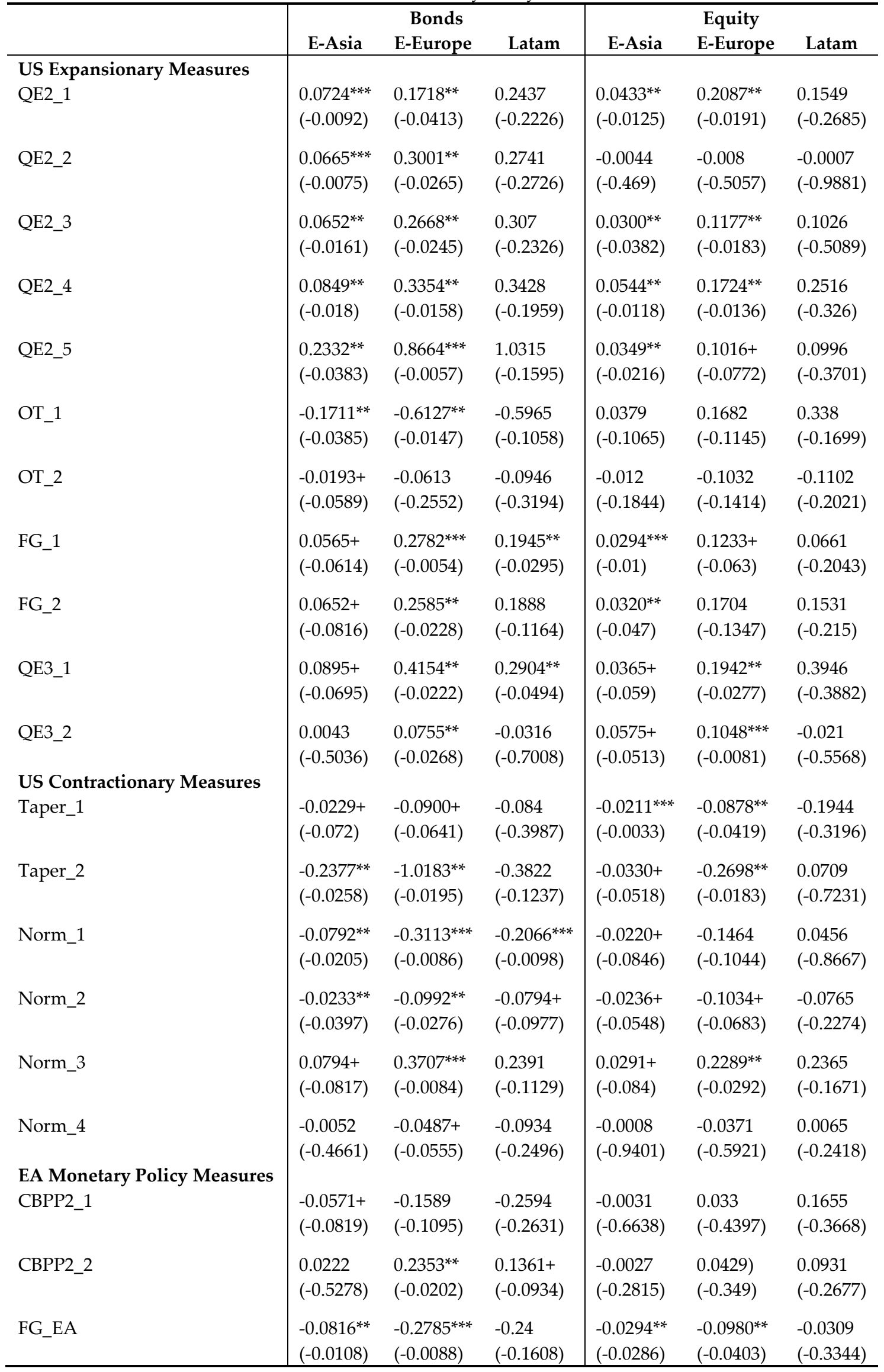




\begin{tabular}{|c|c|c|c|c|c|c|}
\hline PQE & $\begin{array}{l}-0.0424^{* *} \\
(-0.0251)\end{array}$ & $\begin{array}{l}-0.1489^{* *} \\
(-0.0149)\end{array}$ & $\begin{array}{l}-0.0952 \\
(-0.1228)\end{array}$ & $\begin{array}{l}0.0048 \\
(-0.1361)\end{array}$ & $\begin{array}{l}0.0482 \\
(-0.3455)\end{array}$ & $\begin{array}{l}-0.0264 \\
(-0.661)\end{array}$ \\
\hline СВРР3 & $\begin{array}{l}0.0226^{* *} \\
(-0.0234)\end{array}$ & $\begin{array}{l}0.1058^{* * *} \\
(-0.0029)\end{array}$ & $\begin{array}{l}-0.0391^{* *} \\
(-0.047)\end{array}$ & $\begin{array}{l}-0.0223+ \\
(-0.0745)\end{array}$ & $\begin{array}{l}-0.0727 \\
(-0.2692)\end{array}$ & $\begin{array}{l}-0.1564 \\
(-0.5701)\end{array}$ \\
\hline TLTRO1_1 & $\begin{array}{l}-0.0148 \\
(-0.1329)\end{array}$ & $\begin{array}{l}-0.0359 \\
(-0.4029)\end{array}$ & $\begin{array}{l}-0.0709^{* *} \\
(-0.0278)\end{array}$ & $\begin{array}{l}0.0511 \\
(-0.1631)\end{array}$ & $\begin{array}{l}0.0791^{* *} \\
(-0.019)\end{array}$ & $\begin{array}{l}0.0338 \\
(-0.4182)\end{array}$ \\
\hline TLTRO1_2 & $\begin{array}{l}-0.0658^{* *} \\
(-0.0119)\end{array}$ & $\begin{array}{l}-0.1782^{* *} \\
(-0.0362)\end{array}$ & $\begin{array}{c}-0.1959+ \\
(-0.0997)\end{array}$ & $\begin{array}{l}0.0226 \\
(-0.2479)\end{array}$ & $\begin{array}{l}0.0287 \\
(-0.6299)\end{array}$ & $\begin{array}{l}-0.0456 \\
(-0.5848)\end{array}$ \\
\hline PSPP & $\begin{array}{l}-0.0700^{* *} \\
(-0.0178)\end{array}$ & $\begin{array}{l}-0.2860^{* * *} \\
(-0.0085)\end{array}$ & $\begin{array}{l}-0.1110^{* * *} \\
(-0.0028)\end{array}$ & $\begin{array}{l}-0.0139+ \\
(-0.0573)\end{array}$ & $\begin{array}{c}-0.0943+ \\
(-0.0947)\end{array}$ & $\begin{array}{l}0.0957 \\
(-0.1762)\end{array}$ \\
\hline TLTRO2 & $\begin{array}{l}-0.0531^{* *} \\
(-0.0182)\end{array}$ & $\begin{array}{l}-0.1466^{* * *} \\
(-0.0055)\end{array}$ & $\begin{array}{l}-0.1859+ \\
(-0.095)\end{array}$ & $\begin{array}{l}0.0065 \\
(-0.2052)\end{array}$ & $\begin{array}{l}0.0245 \\
(-0.3127)\end{array}$ & $\begin{array}{l}0.1346 \\
(-0.1935)\end{array}$ \\
\hline \multicolumn{7}{|c|}{ UK Monetary Policy Measures } \\
\hline APF1_2 & $\begin{array}{l}0.0417^{* *} \\
(-0.0497)\end{array}$ & $\begin{array}{l}-0.0228 \\
(-0.5683)\end{array}$ & $\begin{array}{l}0.1908 \\
(-0.2625)\end{array}$ & $\begin{array}{l}0.0167 \\
(-0.2351)\end{array}$ & $\begin{array}{l}-0.1311^{* *} \\
(-0.03)\end{array}$ & $\begin{array}{l}-0.0096 \\
(-0.8484)\end{array}$ \\
\hline APF1_3 & $\begin{array}{l}0.1131^{* *} \\
(-0.0147)\end{array}$ & $\begin{array}{l}0.1757^{* *} \\
(-0.0184)\end{array}$ & $\begin{array}{l}0.3154 \\
(-0.1113)\end{array}$ & $\begin{array}{l}0.0201^{* *} \\
(-0.0276)\end{array}$ & $\begin{array}{l}0.0621^{* *} \\
(-0.0129)\end{array}$ & $\begin{array}{l}0.0703 \\
(-0.1329)\end{array}$ \\
\hline APF2_2 & $\begin{array}{l}0.0542+ \\
(-0.0678)\end{array}$ & $\begin{array}{l}0.1783^{* *} \\
(-0.0306)\end{array}$ & $\begin{array}{l}0.1778+ \\
(-0.0687)\end{array}$ & $\begin{array}{l}0.0159^{* *} \\
(-0.0186)\end{array}$ & $\begin{array}{l}0.1054+ \\
(-0.076)\end{array}$ & $\begin{array}{l}-0.0375 \\
(-0.2875)\end{array}$ \\
\hline APF2_3 & $\begin{array}{l}0.1377 \\
(-0.1014)\end{array}$ & $\begin{array}{l}0.6668^{* *} \\
(-0.0203)\end{array}$ & $\begin{array}{l}0.4321 \\
(-0.1055)\end{array}$ & $\begin{array}{l}-0.008 \\
(-0.3645)\end{array}$ & $\begin{array}{l}0.0165 \\
(-0.4653)\end{array}$ & $\begin{array}{l}-0.0233 \\
(-0.2599)\end{array}$ \\
\hline TFS & $\begin{array}{l}0.0239 \\
(-0.2822)\end{array}$ & $\begin{array}{l}0.1385^{* * *} \\
(-0.0055)\end{array}$ & $\begin{array}{l}0.1532 \\
(-0.1954)\end{array}$ & $\begin{array}{l}0.0131+ \\
(-0.0937)\end{array}$ & $\begin{array}{l}0.0877^{* *} \\
(-0.0345)\end{array}$ & $\begin{array}{l}0.1095 \\
(-0.1274)\end{array}$ \\
\hline \multicolumn{7}{|c|}{ Pull and Push Factors } \\
\hline FX-Growth-Ratet-1 & $\begin{array}{l}-0.0122+ \\
(-0.0544)\end{array}$ & $\begin{array}{l}-0.0198^{* * *} \\
(-0.0019)\end{array}$ & $\begin{array}{l}-0.0392+ \\
(-0.0933)\end{array}$ & $\begin{array}{c}-0.0058+ \\
(-0.0639)\end{array}$ & $\begin{array}{l}-0.0146^{* *} \\
(-0.0216)\end{array}$ & $\begin{array}{l}-0.0306+ \\
(-0.0955)\end{array}$ \\
\hline Interest-Rate-Difft-1 & $\begin{array}{l}0.0065 \\
(-0.4294)\end{array}$ & $\begin{array}{l}0.0095 \\
(-0.7014)\end{array}$ & $\begin{array}{l}-0.0537 \\
(-0.1553)\end{array}$ & & & \\
\hline Stocks Returnst-1 & & & & $\begin{array}{l}0.5574^{* *} \\
(-0.0163)\end{array}$ & $\begin{array}{l}2.2579^{* *} \\
(-0.0289)\end{array}$ & $\begin{array}{l}3.4571 \\
(-0.1661)\end{array}$ \\
\hline $\mathrm{VIX}_{\mathrm{t}-1}$ & $\begin{array}{l}0.0024^{* *} \\
(-0.0254)\end{array}$ & $\begin{array}{l}0.0050^{* *} \\
(-0.0302)\end{array}$ & $\begin{array}{l}0.011 \\
(-0.1683)\end{array}$ & $\begin{array}{l}0.0001 \\
(-0.9735)\end{array}$ & $\begin{array}{l}-0.0001 \\
(-0.8536)\end{array}$ & $\begin{array}{l}-0.0037 \\
(-0.1741)\end{array}$ \\
\hline Oil-Pricest-1 & $\begin{array}{l}0.0030^{* *} \\
(-0.0133)\end{array}$ & $\begin{array}{l}0.0090^{* *} \\
(-0.0117)\end{array}$ & $\begin{array}{l}0.0060+ \\
(-0.0684)\end{array}$ & $\begin{array}{l}0.0009^{* * *} \\
(-0.0068)\end{array}$ & $\begin{array}{l}0.0040^{* *} \\
(-0.0203)\end{array}$ & $\begin{array}{l}0.0035 \\
(-0.2631)\end{array}$ \\
\hline Observations & 3017 & 2113 & 2150 & 3017 & 2113 & 2150 \\
\hline Countries & 7 & 5 & 5 & 7 & 5 & 5 \\
\hline
\end{tabular}


Table C2. Effects of Advanced Economies Monetary Policy Measures in EA Portfolio Flows to EMEs

\begin{tabular}{|c|c|c|c|c|c|c|}
\hline & \multicolumn{3}{|c|}{ Bonds } & \multicolumn{3}{|c|}{ Equity } \\
\hline & E-Asia & E-Europe & Latam & E-Asia & E-Europe & Latam \\
\hline US Expansionary Measures & & & & & & \\
\hline QE2_1 & $\begin{array}{l}0.0361^{* * *} \\
(0.0050)\end{array}$ & $\begin{array}{l}0.0341 \\
(0.3619)\end{array}$ & $\begin{array}{l}0.0599 \\
(0.5219)\end{array}$ & $\begin{array}{l}0.0024^{* *} \\
(0.0236)\end{array}$ & $\begin{array}{l}0.0025 \\
(0.4458)\end{array}$ & $\begin{array}{l}0.0102 \\
(0.3901)\end{array}$ \\
\hline QE2_2 & $\begin{array}{l}0.0451^{* * *} \\
(0.0060)\end{array}$ & $\begin{array}{l}0.0915 \\
(0.1743)\end{array}$ & $\begin{array}{l}0.1038 \\
(0.3750)\end{array}$ & $\begin{array}{l}0.0058 \\
(0.1341)\end{array}$ & $\begin{array}{l}0.0295^{* *} \\
(0.0419)\end{array}$ & $\begin{array}{l}0.0061 \\
(0.5508)\end{array}$ \\
\hline QE2_3 & $\begin{array}{l}0.0270^{* *} \\
(0.0409)\end{array}$ & $\begin{array}{l}0.0931^{* *} \\
(0.0213)\end{array}$ & $\begin{array}{l}0.1302 \\
(0.1344)\end{array}$ & $\begin{array}{l}0.0201+ \\
(0.0524)\end{array}$ & $\begin{array}{l}0.0527 \\
(0.1016)\end{array}$ & $\begin{array}{l}0.0513 \\
(0.1300)\end{array}$ \\
\hline QE2_4 & $\begin{array}{l}0.0543^{* *} \\
(0.0144)\end{array}$ & $\begin{array}{l}0.1427^{* * *} \\
(0.0090)\end{array}$ & $\begin{array}{l}0.1963 \\
(0.1201)\end{array}$ & $\begin{array}{l}0.0061^{* *} \\
(0.0271)\end{array}$ & $\begin{array}{l}0.0700 \\
(0.1034)\end{array}$ & $\begin{array}{l}0.0625 \\
(0.2207)\end{array}$ \\
\hline QE2_5 & $\begin{array}{l}0.0227^{* *} \\
(0.0109)\end{array}$ & $\begin{array}{l}0.0677^{* * *} \\
(0.0048)\end{array}$ & $\begin{array}{l}0.0880^{* *} \\
(0.0391)\end{array}$ & $\begin{array}{l}0.0050^{* *} \\
(0.0173)\end{array}$ & $\begin{array}{l}0.0250+ \\
(0.0672)\end{array}$ & $\begin{array}{l}0.0374 \\
(0.2317)\end{array}$ \\
\hline OT_1 & $\begin{array}{l}-0.1387^{* *} \\
(0.0404)\end{array}$ & $\begin{array}{l}-0.5751^{* *} \\
(0.0202)\end{array}$ & $\begin{array}{l}-0.5667 \\
(0.1055)\end{array}$ & $\begin{array}{l}-0.0148 \\
(0.1718)\end{array}$ & $\begin{array}{l}-0.0607^{* *} \\
(0.0214)\end{array}$ & $\begin{array}{l}-0.0447 \\
(0.1834)\end{array}$ \\
\hline OT_2 & $\begin{array}{l}0.0381+ \\
(0.0554)\end{array}$ & $\begin{array}{l}0.1405^{* *} \\
(0.0149)\end{array}$ & $\begin{array}{l}0.0960 \\
(0.1125)\end{array}$ & $\begin{array}{l}-0.0041^{* *} \\
(0.0485)\end{array}$ & $\begin{array}{l}-0.0238 \\
(0.1074)\end{array}$ & $\begin{array}{l}0.0124 \\
(0.6578)\end{array}$ \\
\hline FG_1 & $\begin{array}{l}-0.0732^{* *} \\
(0.0357)\end{array}$ & $\begin{array}{l}-0.2881^{* *} \\
(0.0426)\end{array}$ & $\begin{array}{l}-0.3790 \\
(0.1179)\end{array}$ & $\begin{array}{l}-0.0011 \\
(0.3994)\end{array}$ & $\begin{array}{l}-0.0898 \\
(0.3142)\end{array}$ & $\begin{array}{l}-0.0336 \\
(0.2402)\end{array}$ \\
\hline FG_2 & $\begin{array}{l}0.0362+ \\
(0.0511)\end{array}$ & $\begin{array}{l}0.0095 \\
(0.8685)\end{array}$ & $\begin{array}{l}0.0501 \\
(0.4621)\end{array}$ & $\begin{array}{l}0.0081^{* *} \\
(0.0236)\end{array}$ & $\begin{array}{l}0.0533 \\
(0.2058)\end{array}$ & $\begin{array}{l}0.0508 \\
(0.4038)\end{array}$ \\
\hline QE3_1 & $\begin{array}{l}-0.0087^{* *} \\
(0.0218)\end{array}$ & $\begin{array}{l}-0.0547^{* *} \\
(0.0230)\end{array}$ & $\begin{array}{l}-0.0303 \\
(0.1751)\end{array}$ & $\begin{array}{l}0.0011 \\
(0.6072)\end{array}$ & $\begin{array}{l}0.0225 \\
(0.1408)\end{array}$ & $\begin{array}{l}0.0281 \\
(0.4066)\end{array}$ \\
\hline QE3_2 & $\begin{array}{l}0.0139^{* *} \\
(0.0133)\end{array}$ & $\begin{array}{l}0.0253+ \\
(0.0946)\end{array}$ & $\begin{array}{l}0.0209 \\
(0.3605)\end{array}$ & $\begin{array}{l}0.0078^{* * *} \\
(0.0098)\end{array}$ & $\begin{array}{l}0.0538^{* *} \\
(0.0368)\end{array}$ & $\begin{array}{l}0.0361 \\
(0.1343)\end{array}$ \\
\hline US Contractionary Measures & & & & & & \\
\hline Taper_1 & $\begin{array}{l}-0.0449^{* *} \\
(0.0346)\end{array}$ & $\begin{array}{l}-0.2767^{* *} \\
(0.0460)\end{array}$ & $\begin{array}{l}-0.0581 \\
(0.1843)\end{array}$ & $\begin{array}{l}-0.0056^{* *} \\
(0.0132)\end{array}$ & $\begin{array}{l}-0.0448^{* *} \\
(0.0180)\end{array}$ & $\begin{array}{l}-0.0342 \\
(0.2524)\end{array}$ \\
\hline Taper_2 & $\begin{array}{l}-0.1359^{* *} \\
(0.0117)\end{array}$ & $\begin{array}{l}-0.5836^{* *} \\
(0.0289)\end{array}$ & $\begin{array}{c}-0.1738+ \\
(0.0666)\end{array}$ & $\begin{array}{l}-0.0133^{* *} \\
(0.0188)\end{array}$ & $\begin{array}{l}-0.0468+ \\
(0.0540)\end{array}$ & $\begin{array}{c}-0.0814 \\
(0.2112)\end{array}$ \\
\hline Norm_1 & $\begin{array}{l}-0.0111^{* *} \\
(0.0370)\end{array}$ & $\begin{array}{l}-0.0378 \\
(0.2544)\end{array}$ & $\begin{array}{l}-0.0189^{* *} \\
(0.0465)\end{array}$ & $\begin{array}{l}0.0037+ \\
(0.0648)\end{array}$ & $\begin{array}{l}-0.0008 \\
(0.9818)\end{array}$ & $\begin{array}{l}0.0201 \\
(0.2144)\end{array}$ \\
\hline Norm_2 & $\begin{array}{l}-0.0550+ \\
(0.0514)\end{array}$ & $\begin{array}{l}-0.2760^{* * *} \\
(0.0033)\end{array}$ & $\begin{array}{c}-0.1584+ \\
(0.0763)\end{array}$ & $\begin{array}{c}-0.0094+ \\
(0.0709)\end{array}$ & $\begin{array}{l}-0.0513+ \\
(0.0764)\end{array}$ & $\begin{array}{c}-0.0827 \\
(0.1092)\end{array}$ \\
\hline Norm_3 & $\begin{array}{l}0.0311+ \\
(0.0748)\end{array}$ & $\begin{array}{l}0.1762^{* * *} \\
(0.0085)\end{array}$ & $\begin{array}{l}0.1208 \\
(0.1111)\end{array}$ & $\begin{array}{l}0.0057^{* *} \\
(0.0175)\end{array}$ & $\begin{array}{l}0.0450+ \\
(0.0537)\end{array}$ & $\begin{array}{l}0.0418 \\
(0.1688)\end{array}$ \\
\hline Norm_4 & $\begin{array}{l}0.0226+ \\
(0.0778)\end{array}$ & $\begin{array}{l}0.1129^{* *} \\
(0.0470)\end{array}$ & $\begin{array}{l}0.0837 \\
(0.1469)\end{array}$ & $\begin{array}{c}0.0028+ \\
(0.0716)\end{array}$ & $\begin{array}{c}0.0167+ \\
(0.0624)\end{array}$ & $\begin{array}{l}0.0367 \\
(0.1213)\end{array}$ \\
\hline EA Monetary Policy Measures & & & & & & \\
\hline CBPP2_1 & $\begin{array}{l}-0.0294^{* *} \\
(0.0146)\end{array}$ & $\begin{array}{l}-0.0324 \\
(0.2307)\end{array}$ & $\begin{array}{l}-0.1229 \\
(0.1861)\end{array}$ & $\begin{array}{l}-0.0090^{* *} \\
(0.0102)\end{array}$ & $\begin{array}{l}-0.0946 \\
(0.1935)\end{array}$ & $\begin{array}{c}-0.0884 \\
(0.2823)\end{array}$ \\
\hline CBPP2_2 & $\begin{array}{l}0.0041 \\
(0.7168)\end{array}$ & $\begin{array}{l}0.0677^{* *} \\
(0.0440)\end{array}$ & $\begin{array}{l}-0.0014 \\
(0.9255)\end{array}$ & $\begin{array}{l}0.0053 \\
(0.1430)\end{array}$ & $\begin{array}{l}0.0096 \\
(0.3895)\end{array}$ & $\begin{array}{l}-0.0150 \\
(0.3836)\end{array}$ \\
\hline FG_EA & $\begin{array}{l}-0.0231^{* *} \\
(0.0130)\end{array}$ & $\begin{array}{l}-0.0866^{* *} \\
(0.0168)\end{array}$ & $\begin{array}{c}-0.0777+ \\
(0.0847)\end{array}$ & $\begin{array}{l}-0.0094^{* *} \\
(0.0468)\end{array}$ & $\begin{array}{c}-0.0467+ \\
(0.0728)\end{array}$ & $\begin{array}{l}-0.0370 \\
(0.1667)\end{array}$ \\
\hline
\end{tabular}




\begin{tabular}{|c|c|c|c|c|c|c|}
\hline PQE & $\begin{array}{l}0.0287^{* *} \\
(0.0296)\end{array}$ & $\begin{array}{l}0.0532^{* * *} \\
(0.0016)\end{array}$ & $\begin{array}{l}-0.0068 \\
(0.5509)\end{array}$ & $\begin{array}{l}0.0012 \\
(0.1102)\end{array}$ & $\begin{array}{l}0.0058 \\
(0.6614)\end{array}$ & $\begin{array}{l}0.0110 \\
(0.4846)\end{array}$ \\
\hline СВРР3 & $\begin{array}{l}0.0068 \\
(0.1824)\end{array}$ & $\begin{array}{l}0.0393 \\
(0.1637)\end{array}$ & $\begin{array}{l}-0.0055 \\
(0.5143)\end{array}$ & $\begin{array}{c}-0.0024+ \\
(0.0926)\end{array}$ & $\begin{array}{l}-0.0305^{* *} \\
(0.0153)\end{array}$ & $\begin{array}{l}-0.0567 \\
(0.4444)\end{array}$ \\
\hline TLTRO1_1 & $\begin{array}{l}0.0294^{* *} \\
(0.0161)\end{array}$ & $\begin{array}{l}0.4564^{* *} \\
(0.0499)\end{array}$ & $\begin{array}{l}0.0029 \\
(0.8785)\end{array}$ & $\begin{array}{l}0.0032^{* *} \\
(0.0323)\end{array}$ & $\begin{array}{l}0.0153 \\
(0.2071)\end{array}$ & $\begin{array}{l}0.0058 \\
(0.7319)\end{array}$ \\
\hline TLTRO1_2 & $\begin{array}{l}0.0305^{* *} \\
(0.0329)\end{array}$ & $\begin{array}{l}0.1782^{* *} \\
(0.0122)\end{array}$ & $\begin{array}{l}-0.0145 \\
(0.4891)\end{array}$ & $\begin{array}{l}0.0055 \\
(0.2976)\end{array}$ & $\begin{array}{l}-0.0040 \\
(0.7634)\end{array}$ & $\begin{array}{l}0.0076 \\
(0.6366)\end{array}$ \\
\hline PSPP & $\begin{array}{l}0.0054 \\
(0.1703)\end{array}$ & $\begin{array}{l}0.0385 \\
(0.4757)\end{array}$ & $\begin{array}{l}-0.0152 \\
(0.1811)\end{array}$ & $\begin{array}{l}-0.0019 \\
(0.1865)\end{array}$ & $\begin{array}{l}-0.0041 \\
(0.7164)\end{array}$ & $\begin{array}{l}-0.0111 \\
(0.3254)\end{array}$ \\
\hline TLTRO2 & $\begin{array}{l}0.0224 \\
(0.1811)\end{array}$ & $\begin{array}{l}0.1326^{* * *} \\
(0.0060)\end{array}$ & $\begin{array}{l}0.0309^{* *} \\
(0.0322)\end{array}$ & $\begin{array}{l}-0.0049^{* *} \\
(0.0283)\end{array}$ & $\begin{array}{c}-0.0501+ \\
(0.0509)\end{array}$ & $\begin{array}{l}-0.0261 \\
(0.5796)\end{array}$ \\
\hline \multicolumn{7}{|c|}{ UK Monetary Policy Measures } \\
\hline APF1_2 & $\begin{array}{l}0.0444^{* *} \\
(0.0148)\end{array}$ & $\begin{array}{l}0.0667^{* * *} \\
(0.0044)\end{array}$ & $\begin{array}{l}0.2161 \\
(0.1049)\end{array}$ & $\begin{array}{l}0.0050^{* *} \\
(0.0334)\end{array}$ & $\begin{array}{l}0.0436+ \\
(0.0536)\end{array}$ & $\begin{array}{l}0.0375+ \\
(0.0906)\end{array}$ \\
\hline APF1_3 & $\begin{array}{l}0.0119 \\
(0.1185)\end{array}$ & $\begin{array}{l}0.1000+ \\
(0.0626)\end{array}$ & $\begin{array}{l}0.0157 \\
(0.4242)\end{array}$ & $\begin{array}{l}0.0081^{* *} \\
(0.0177)\end{array}$ & $\begin{array}{l}0.0489 \\
(0.1223)\end{array}$ & $\begin{array}{l}0.0247 \\
(0.4369)\end{array}$ \\
\hline APF2_2 & $\begin{array}{l}0.0686^{* *} \\
(0.0169)\end{array}$ & $\begin{array}{l}0.1557^{* * *} \\
(0.0073)\end{array}$ & $\begin{array}{l}0.1745 \\
(0.1211)\end{array}$ & $\begin{array}{l}0.0057 \\
(0.1116)\end{array}$ & $\begin{array}{l}0.0554 \\
(0.1585)\end{array}$ & $\begin{array}{l}0.0386 \\
(0.4526)\end{array}$ \\
\hline APF2_3 & $\begin{array}{l}0.0378+ \\
(0.0534)\end{array}$ & $\begin{array}{l}0.1604^{* *} \\
(0.0180)\end{array}$ & $\begin{array}{l}0.0941+ \\
(0.0737)\end{array}$ & $\begin{array}{l}0.0004 \\
(0.7945)\end{array}$ & $\begin{array}{l}-0.0192 \\
(0.2868)\end{array}$ & $\begin{array}{l}0.0061 \\
(0.7130)\end{array}$ \\
\hline TFS & $\begin{array}{l}0.0051 \\
(0.3110)\end{array}$ & $\begin{array}{l}0.0129 \\
(0.4912)\end{array}$ & $\begin{array}{l}0.0517 \\
(0.1212)\end{array}$ & $\begin{array}{l}0.0042+ \\
(0.0523)\end{array}$ & $\begin{array}{l}0.0033 \\
(0.8900)\end{array}$ & $\begin{array}{l}0.0265^{* *} \\
(0.0326)\end{array}$ \\
\hline \multicolumn{7}{|c|}{ Pull and Push Factors } \\
\hline FX-Growth-Ratet-1 & $\begin{array}{l}-0.0083^{* *} \\
(0.0432)\end{array}$ & $\begin{array}{l}-0.0203^{* * *} \\
(0.0034)\end{array}$ & $\begin{array}{c}-0.0246+ \\
(0.0818)\end{array}$ & $\begin{array}{l}-0.0017 \\
(0.1070)\end{array}$ & $\begin{array}{l}-0.0043^{* *} \\
(0.0420)\end{array}$ & $\begin{array}{l}-0.0067 \\
(0.1411)\end{array}$ \\
\hline Interest-Rate-Difft-1 & $\begin{array}{l}-0.0015 \\
(0.4187)\end{array}$ & $\begin{array}{l}0.0006 \\
(0.8318)\end{array}$ & $\begin{array}{l}-0.0116 \\
(0.1829)\end{array}$ & & & \\
\hline Stocks Returnst-1 & & & & $\begin{array}{l}0.0733^{* *} \\
(0.0295)\end{array}$ & $\begin{array}{l}0.4332 \\
(0.1747)\end{array}$ & $\begin{array}{l}0.5483 \\
(0.1452)\end{array}$ \\
\hline $\mathrm{VIX}_{\mathrm{t}-1}$ & $\begin{array}{l}-0.0002 \\
(0.5574)\end{array}$ & $\begin{array}{l}-0.0045^{* * *} \\
(0.0069)\end{array}$ & $\begin{array}{l}0.0004 \\
(0.7550)\end{array}$ & $\begin{array}{l}-0.0002^{* *} \\
(0.0313)\end{array}$ & $\begin{array}{l}-0.0010^{* *} \\
(0.0257)\end{array}$ & $\begin{array}{l}-0.0009 \\
(0.1130)\end{array}$ \\
\hline Oil-Pricest-1 & $\begin{array}{l}0.0002 \\
(0.2484)\end{array}$ & $\begin{array}{l}0.0001 \\
(0.8765)\end{array}$ & $\begin{array}{l}-0.0004 \\
(0.4822)\end{array}$ & $\begin{array}{l}0.0001^{* *} \\
(0.0286)\end{array}$ & $\begin{array}{l}0.0011 \\
(0.1005)\end{array}$ & $\begin{array}{l}0.0006 \\
(0.2187)\end{array}$ \\
\hline Observations & 3017 & 2113 & 2150 & 3017 & 2113 & 2150 \\
\hline Countries & 7 & 5 & 5 & 7 & 5 & 5 \\
\hline
\end{tabular}


Table C3. Effects of Advanced Economies Monetary Policy Measures in UK Portfolio Flows to EMEs

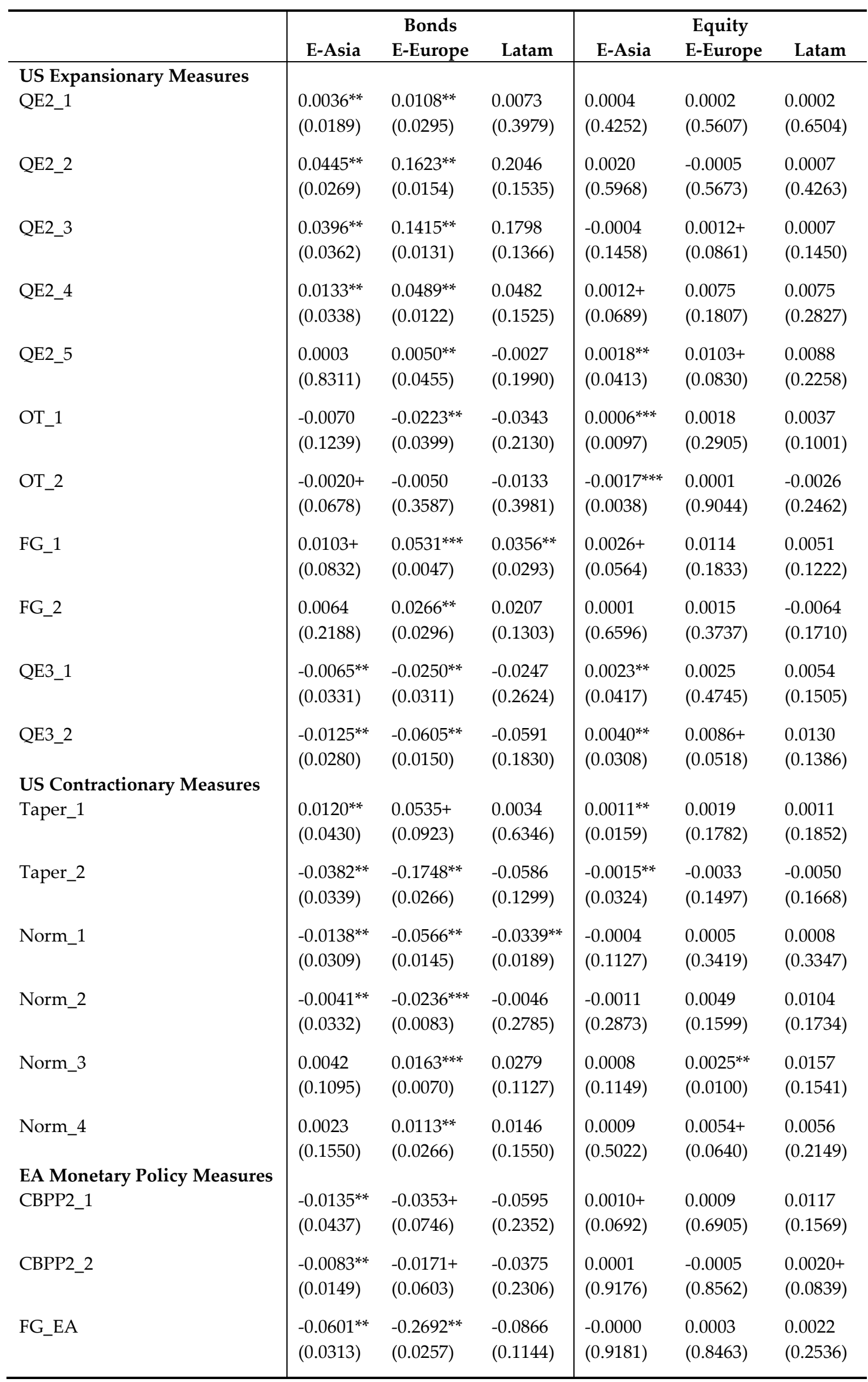




\begin{tabular}{|c|c|c|c|c|c|c|}
\hline PQE & $\begin{array}{l}-0.0052+ \\
(0.0836)\end{array}$ & $\begin{array}{l}-0.0191 \\
(0.2112)\end{array}$ & $\begin{array}{l}-0.0106 \\
(0.1369)\end{array}$ & $\begin{array}{l}0.0003 \\
(0.2615)\end{array}$ & $\begin{array}{l}-0.0018 \\
(0.1154)\end{array}$ & $\begin{array}{l}-0.0022 \\
(0.1473)\end{array}$ \\
\hline СВРP3 & $\begin{array}{l}-0.0000 \\
(0.9639)\end{array}$ & $\begin{array}{l}-0.0035 \\
(0.3724)\end{array}$ & $\begin{array}{l}-0.0088^{* *} \\
(0.0349)\end{array}$ & $\begin{array}{l}-0.0006+ \\
(0.0897)\end{array}$ & $\begin{array}{l}-0.0024 \\
(0.2119)\end{array}$ & $\begin{array}{l}-0.0035 \\
(0.2639)\end{array}$ \\
\hline TLTRO1_1 & $\begin{array}{l}0.0038^{* *} \\
(0.0256)\end{array}$ & $\begin{array}{l}0.0157^{* *} \\
(0.0287)\end{array}$ & $\begin{array}{l}-0.0039 \\
(0.2275)\end{array}$ & $\begin{array}{l}0.0029^{* *} \\
(0.0453)\end{array}$ & $\begin{array}{l}0.0048+ \\
(0.0942)\end{array}$ & $\begin{array}{l}-0.0438 \\
(0.1241)\end{array}$ \\
\hline TLTRO1_2 & $\begin{array}{l}0.0011 \\
(0.4390)\end{array}$ & $\begin{array}{l}0.0056 \\
(0.5317)\end{array}$ & $\begin{array}{l}-0.0173 \\
(0.1381)\end{array}$ & $\begin{array}{l}-0.0034^{* *} \\
(0.0194)\end{array}$ & $\begin{array}{c}-0.0098+ \\
(0.0678)\end{array}$ & $\begin{array}{l}-0.0155 \\
(0.1535)\end{array}$ \\
\hline PSPP & $\begin{array}{c}-0.0018+ \\
(0.0702)\end{array}$ & $\begin{array}{l}-0.0115 \\
(0.1703)\end{array}$ & $\begin{array}{l}-0.0062 \\
(0.1105)\end{array}$ & $\begin{array}{l}-0.0037^{* *} \\
(0.0163)\end{array}$ & $\begin{array}{l}-0.0068 \\
(0.1209)\end{array}$ & $\begin{array}{l}-0.0127 \\
(0.1471)\end{array}$ \\
\hline TLTRO2 & $\begin{array}{l}-0.0124^{* *} \\
(0.0144)\end{array}$ & $\begin{array}{l}-0.0379^{* *} \\
(0.0167)\end{array}$ & $\begin{array}{c}-0.0325+ \\
(0.0981)\end{array}$ & $\begin{array}{l}-0.0004 \\
(0.1031)\end{array}$ & $\begin{array}{l}0.0045+ \\
(0.0711)\end{array}$ & $\begin{array}{l}0.0267+ \\
(0.0895)\end{array}$ \\
\hline \multicolumn{7}{|c|}{ UK Monetary Policy Measures } \\
\hline APF1_2 & $\begin{array}{l}-0.0070^{* *} \\
(0.0184)\end{array}$ & $\begin{array}{c}-0.0236+ \\
(0.0591)\end{array}$ & $\begin{array}{l}-0.0429 \\
(0.1800)\end{array}$ & $\begin{array}{l}0.0006 \\
(0.1157)\end{array}$ & $\begin{array}{l}-0.0005^{* *} \\
(0.0446)\end{array}$ & $\begin{array}{l}0.0008 \\
(0.1707)\end{array}$ \\
\hline APF1_3 & $\begin{array}{l}-0.0135^{* *} \\
(0.0354)\end{array}$ & $\begin{array}{l}-0.0350^{* *} \\
(0.0393)\end{array}$ & $\begin{array}{l}-0.0856 \\
(0.1606)\end{array}$ & $\begin{array}{l}-0.0006 \\
(0.2058)\end{array}$ & $\begin{array}{c}-0.0009+ \\
(0.0681)\end{array}$ & $\begin{array}{l}-0.0005 \\
(0.5017)\end{array}$ \\
\hline APF2_2 & $\begin{array}{l}0.0388+ \\
(0.0531)\end{array}$ & $\begin{array}{l}0.1256^{* *} \\
(0.0119)\end{array}$ & $\begin{array}{l}0.1302 \\
(0.1173)\end{array}$ & $\begin{array}{l}0.0065^{* *} \\
(0.0454)\end{array}$ & $\begin{array}{l}0.0045+ \\
(0.0568)\end{array}$ & $\begin{array}{l}0.0036 \\
(0.2881)\end{array}$ \\
\hline APF2_3 & $\begin{array}{l}-0.0116^{* *} \\
(0.0138)\end{array}$ & $\begin{array}{l}-0.0372^{* *} \\
(0.0214)\end{array}$ & $\begin{array}{l}-0.0387 \\
(0.2021)\end{array}$ & $\begin{array}{l}0.0010 \\
(0.2835)\end{array}$ & $\begin{array}{l}-0.0076 \\
(0.1573)\end{array}$ & $\begin{array}{l}-0.0031 \\
(0.2157)\end{array}$ \\
\hline TFS & $\begin{array}{l}0.0001 \\
(0.9805)\end{array}$ & $\begin{array}{l}0.0096+ \\
(0.0637)\end{array}$ & $\begin{array}{l}0.0216 \\
(0.1665)\end{array}$ & $\begin{array}{l}-0.0017^{* *} \\
(0.0380)\end{array}$ & $\begin{array}{c}-0.0046+ \\
(0.0545)\end{array}$ & $\begin{array}{l}0.0083 \\
(0.1037)\end{array}$ \\
\hline \multicolumn{7}{|c|}{ Pull and Push Factors } \\
\hline FX-Growth-Ratet-1 & $\begin{array}{l}-0.0021+ \\
(0.0588)\end{array}$ & $\begin{array}{l}-0.0030^{* *} \\
(0.0346)\end{array}$ & $\begin{array}{l}-0.0050+ \\
(0.0775)\end{array}$ & $\begin{array}{l}-0.0002^{* *} \\
(0.0308)\end{array}$ & $\begin{array}{l}-0.0002 \\
(0.3050)\end{array}$ & $\begin{array}{l}-0.0004^{* *} \\
(0.0468)\end{array}$ \\
\hline Interest-Rate-Difft-1 & $\begin{array}{l}0.0006 \\
(0.4333)\end{array}$ & $\begin{array}{l}0.0005 \\
(0.8374)\end{array}$ & $\begin{array}{c}-0.0085+ \\
(0.0527)\end{array}$ & & & \\
\hline Stocks Returnst-1 & & & & $\begin{array}{l}0.0218^{* *} \\
(0.0276)\end{array}$ & $\begin{array}{l}0.0545 \\
(0.2255)\end{array}$ & $\begin{array}{l}0.0484 \\
(0.1989)\end{array}$ \\
\hline $\mathrm{VIX}_{\mathrm{t}-1}$ & $\begin{array}{l}0.0002^{* *} \\
(0.0494)\end{array}$ & $\begin{array}{l}0.0005 \\
(0.2706)\end{array}$ & $\begin{array}{l}0.0015 \\
(0.2559)\end{array}$ & $\begin{array}{l}0.0000+ \\
(0.0740)\end{array}$ & $\begin{array}{l}0.0001 \\
(0.1904)\end{array}$ & $\begin{array}{l}0.0001 \\
(0.3108)\end{array}$ \\
\hline Oil-Pricest-1 & $\begin{array}{l}0.0002+ \\
(0.0846)\end{array}$ & $\begin{array}{l}0.0011^{* *} \\
(0.0155)\end{array}$ & $\begin{array}{l}0.0008 \\
(0.1041)\end{array}$ & $\begin{array}{l}0.0000 \\
(0.1773)\end{array}$ & $\begin{array}{l}0.0001^{* *} \\
(0.0301)\end{array}$ & $\begin{array}{l}0.0000 \\
(0.1231)\end{array}$ \\
\hline Observations & 3017 & 2113 & 2150 & 3017 & 2113 & 2150 \\
\hline Countries & 7 & 5 & 5 & 7 & 5 & 5 \\
\hline
\end{tabular}


Table C4. Effects of Advanced Economies Monetary Policy Measures in US Portfolio Flows to EMEs

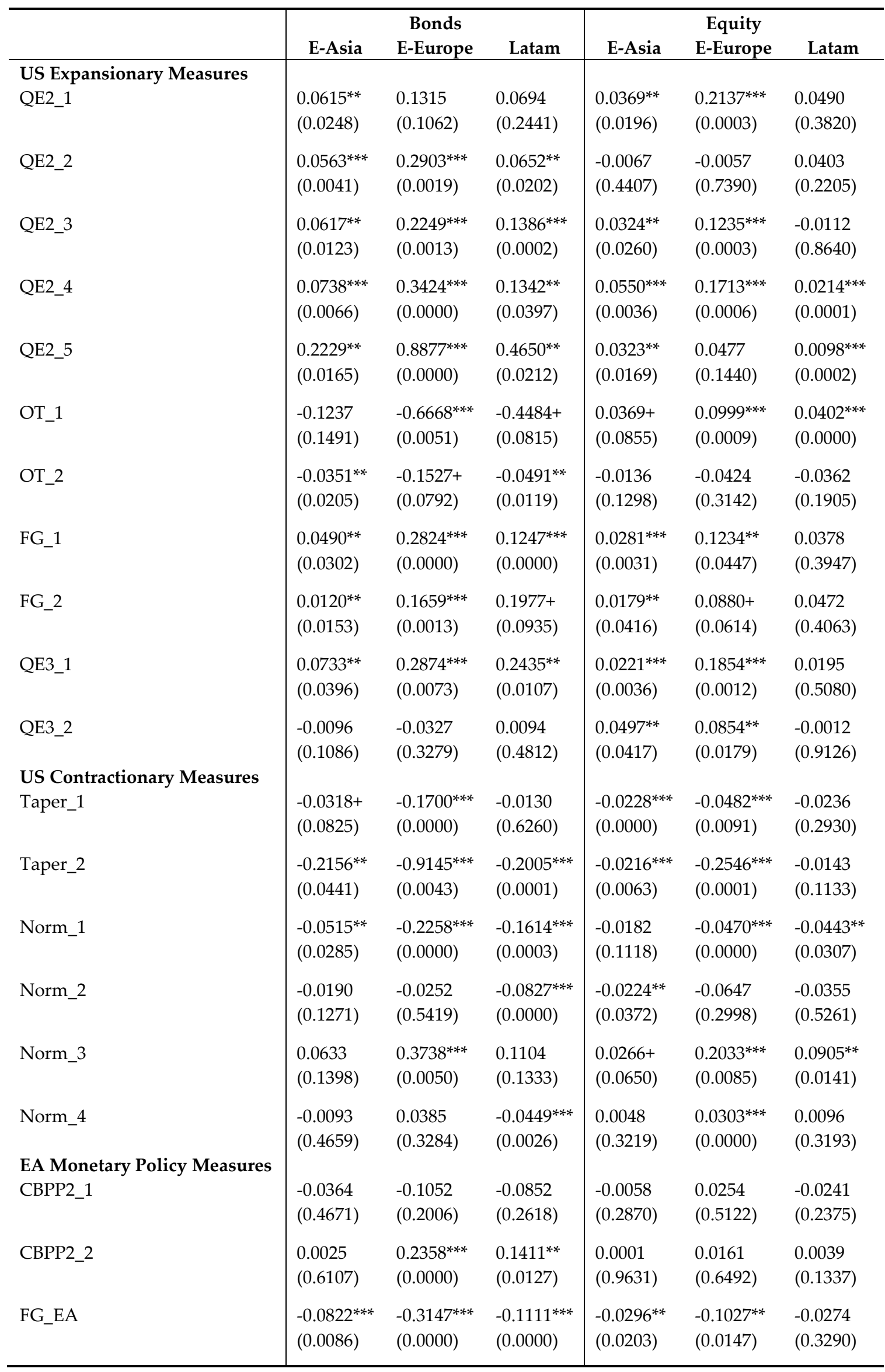




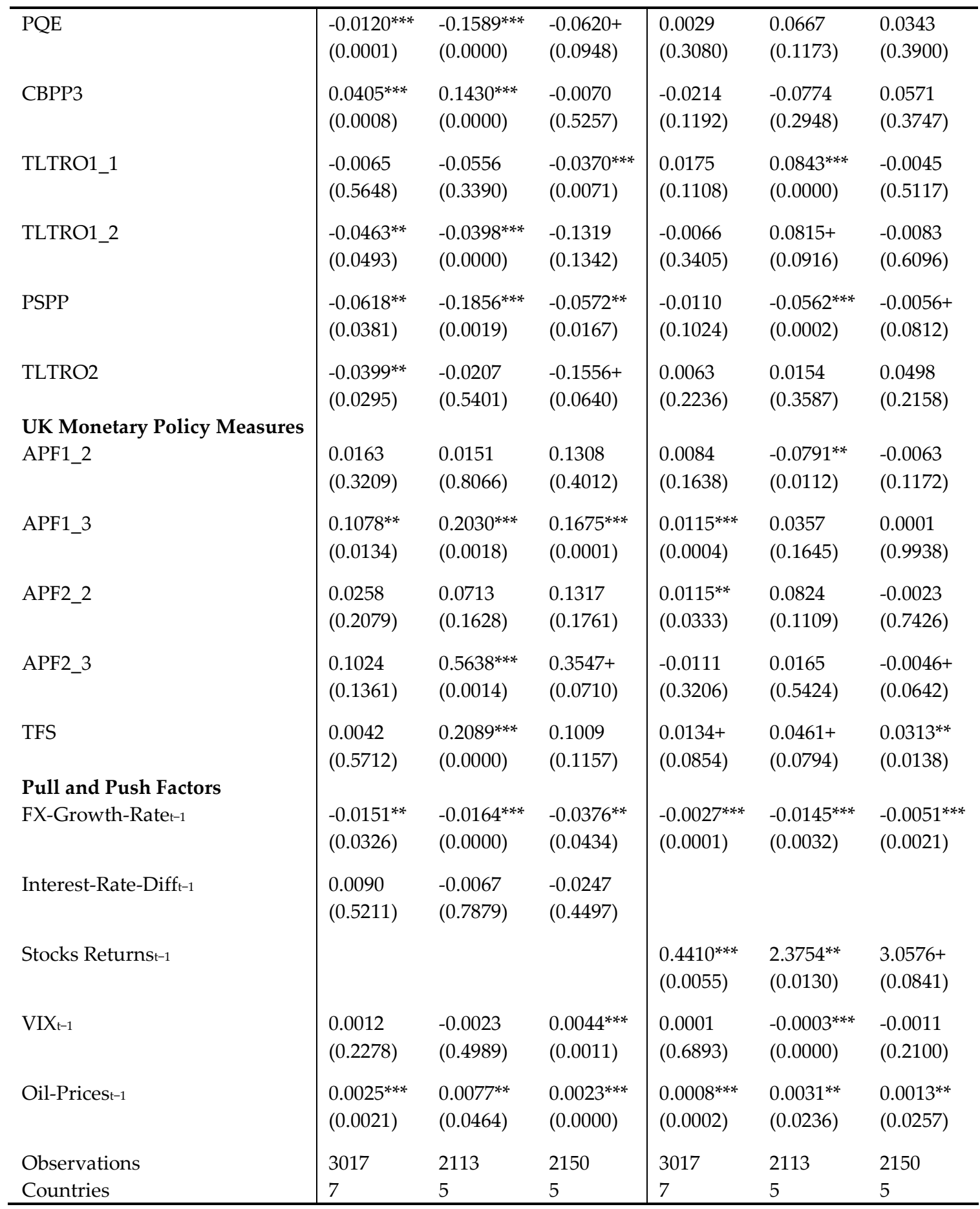

Mean Group Estimator Results, fixed effects included but not reported.

Hamilton (1992) robust standard errors in parenthesis.

P-values in parenthesis, + significant at $10 \% \quad * *$ significant at $5 \% \quad * * *$ significant at $1 \%$. 
Table C5. Effects of Advanced Economies Monetary Policy Measures in EA Portfolio Flows to EMEs

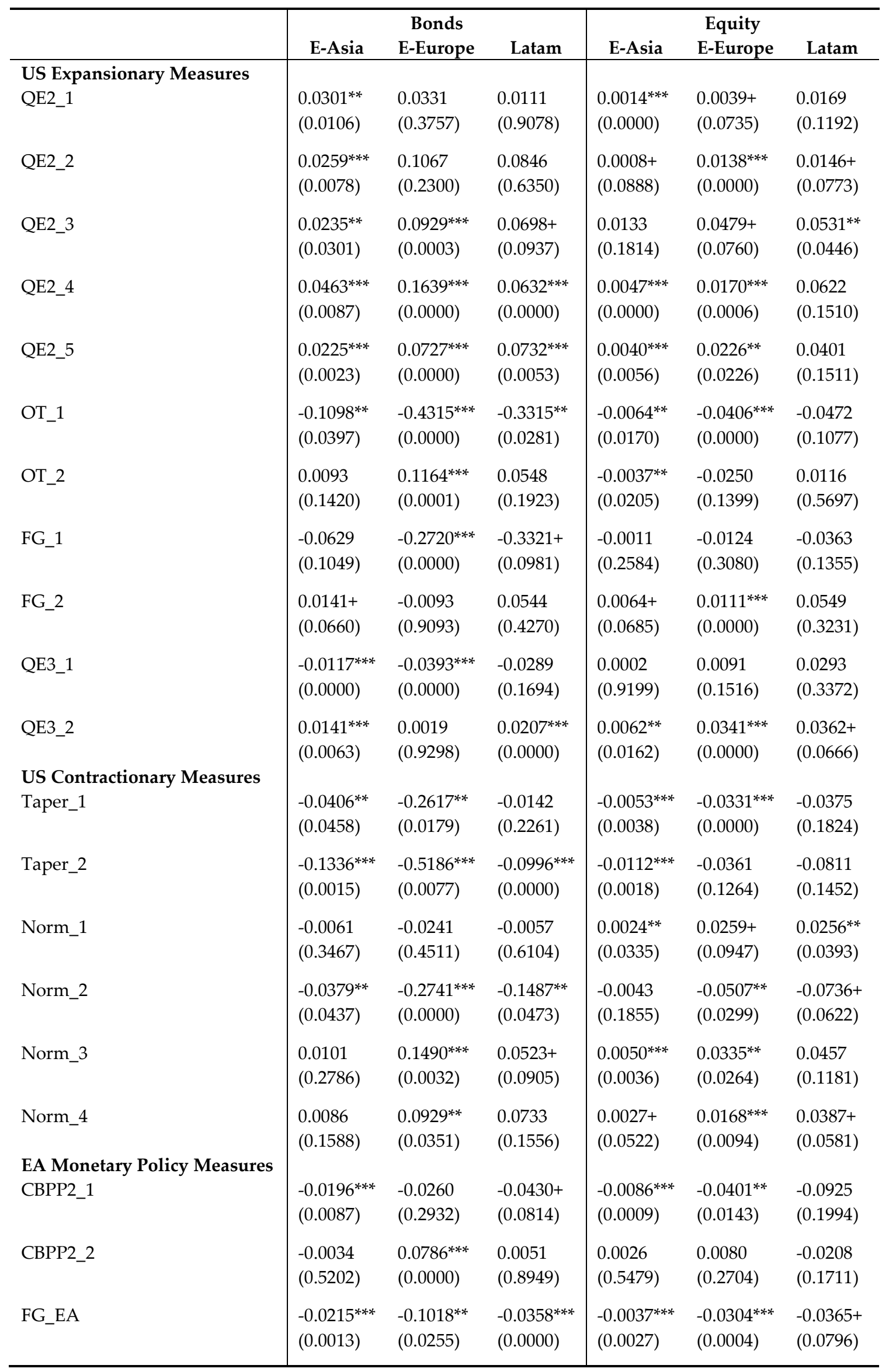




\begin{tabular}{|c|c|c|c|c|c|c|}
\hline PQE & $\begin{array}{l}0.0295^{* * *} \\
(0.0087)\end{array}$ & $\begin{array}{l}0.0525^{* * *} \\
(0.0000)\end{array}$ & $\begin{array}{l}0.0026 \\
(0.5010)\end{array}$ & $\begin{array}{l}0.0010 \\
(0.1723)\end{array}$ & $\begin{array}{l}0.0068 \\
(0.6037)\end{array}$ & $\begin{array}{l}0.0134 \\
(0.3269)\end{array}$ \\
\hline СВРР3 & $\begin{array}{l}0.0120^{* *} \\
(0.0215)\end{array}$ & $\begin{array}{l}0.0303 \\
(0.1388)\end{array}$ & $\begin{array}{l}0.0076 \\
(0.2933)\end{array}$ & $\begin{array}{l}-0.0027^{* *} \\
(0.0173)\end{array}$ & $\begin{array}{l}-0.0260^{* * *} \\
(0.0005)\end{array}$ & $\begin{array}{l}-0.0643 \\
(0.3538)\end{array}$ \\
\hline TLTRO1_1 & $\begin{array}{l}0.0325^{* * *} \\
(0.0014)\end{array}$ & $\begin{array}{l}0.4778^{* *} \\
(0.0485)\end{array}$ & $\begin{array}{l}0.0163 \\
(0.3855)\end{array}$ & $\begin{array}{l}0.0024+ \\
(0.0645)\end{array}$ & $\begin{array}{l}0.0236^{* * *} \\
(0.0015)\end{array}$ & $\begin{array}{l}0.0065 \\
(0.7077)\end{array}$ \\
\hline TLTRO1_2 & $\begin{array}{l}0.0288^{* *} \\
(0.0131)\end{array}$ & $\begin{array}{l}0.2088^{* * *} \\
(0.0023)\end{array}$ & $\begin{array}{l}-0.0107 \\
(0.5834)\end{array}$ & $\begin{array}{l}0.0004 \\
(0.6678)\end{array}$ & $\begin{array}{l}-0.0041 \\
(0.7946)\end{array}$ & $\begin{array}{l}0.0077 \\
(0.5115)\end{array}$ \\
\hline PSPP & $\begin{array}{l}0.0047 \\
(0.4075)\end{array}$ & $\begin{array}{l}0.0098 \\
(0.6276)\end{array}$ & $\begin{array}{l}-0.0052 \\
(0.7251)\end{array}$ & $\begin{array}{l}-0.0018 \\
(0.1533)\end{array}$ & $\begin{array}{l}-0.0013 \\
(0.7566)\end{array}$ & $\begin{array}{l}-0.0155+ \\
(0.0746)\end{array}$ \\
\hline TLTRO2 & $\begin{array}{l}0.0019 \\
(0.3667)\end{array}$ & $\begin{array}{l}0.1494^{* * *} \\
(0.0002)\end{array}$ & $\begin{array}{l}0.0165 \\
(0.1093)\end{array}$ & $\begin{array}{l}-0.0032 \\
(0.1064)\end{array}$ & $\begin{array}{l}-0.0469^{* *} \\
(0.0489)\end{array}$ & $\begin{array}{l}-0.0268 \\
(0.5462)\end{array}$ \\
\hline \multicolumn{7}{|c|}{ UK Monetary Policy Measures } \\
\hline APF1_2 & $\begin{array}{l}0.0460^{* * *} \\
(0.0013)\end{array}$ & $\begin{array}{l}0.0559^{* * *} \\
(0.0001)\end{array}$ & $\begin{array}{l}0.1152 \\
(0.1430)\end{array}$ & $\begin{array}{l}0.0035^{* * *} \\
(0.0023)\end{array}$ & $\begin{array}{l}0.0336^{* *} \\
(0.0101)\end{array}$ & $\begin{array}{l}0.0274+ \\
(0.0645)\end{array}$ \\
\hline APF1_3 & $\begin{array}{l}0.0108 \\
(0.1219)\end{array}$ & $\begin{array}{l}0.0547^{* * *} \\
(0.0084)\end{array}$ & $\begin{array}{l}0.0015 \\
(0.8870)\end{array}$ & $\begin{array}{l}0.0076^{* * *} \\
(0.0015)\end{array}$ & $\begin{array}{l}0.0229^{* *} \\
(0.0139)\end{array}$ & $\begin{array}{l}0.0174 \\
(0.5548)\end{array}$ \\
\hline APF2_2 & $\begin{array}{l}0.0620^{* * *} \\
(0.0046)\end{array}$ & $\begin{array}{l}0.1309^{* * *} \\
(0.0000)\end{array}$ & $\begin{array}{l}0.1257+ \\
(0.0985)\end{array}$ & $\begin{array}{l}0.0027 \\
(0.1349)\end{array}$ & $\begin{array}{l}0.0233^{* *} \\
(0.0243)\end{array}$ & $\begin{array}{l}0.0420 \\
(0.3830)\end{array}$ \\
\hline APF2_3 & $\begin{array}{l}0.0329+ \\
(0.0594)\end{array}$ & $\begin{array}{l}0.1326^{* * *} \\
(0.0000)\end{array}$ & $\begin{array}{l}0.0875^{* *} \\
(0.0306)\end{array}$ & $\begin{array}{l}0.0015^{* * *} \\
(0.0030)\end{array}$ & $\begin{array}{l}-0.0175 \\
(0.2724)\end{array}$ & $\begin{array}{l}0.0055 \\
(0.7327)\end{array}$ \\
\hline TFS & $\begin{array}{l}0.0042 \\
(0.4597)\end{array}$ & $\begin{array}{l}0.0149 \\
(0.5037)\end{array}$ & $\begin{array}{l}0.0328+ \\
(0.0764)\end{array}$ & $\begin{array}{l}0.0028^{* *} \\
(0.0103)\end{array}$ & $\begin{array}{c}0.0191+ \\
(0.0887)\end{array}$ & $\begin{array}{l}0.0221^{* * *} \\
(0.0050)\end{array}$ \\
\hline \multicolumn{7}{|l|}{ Pull and Push Factors } \\
\hline FX-Growth-Ratet-1 & $\begin{array}{l}-0.0104^{* * *} \\
(0.0097)\end{array}$ & $\begin{array}{l}-0.0205^{* * *} \\
(0.0000)\end{array}$ & $\begin{array}{l}-0.0261^{* *} \\
(0.0314)\end{array}$ & $\begin{array}{l}-0.0008^{* *} \\
(0.0385)\end{array}$ & $\begin{array}{l}-0.0037^{* * *} \\
(0.0000)\end{array}$ & $\begin{array}{l}-0.0044+ \\
(0.0721)\end{array}$ \\
\hline Interest-Rate-Difft-1 & $\begin{array}{l}-0.0015 \\
(0.5552)\end{array}$ & $\begin{array}{l}0.0128 \\
(0.2740)\end{array}$ & $\begin{array}{l}-0.0083 \\
(0.4372)\end{array}$ & & & \\
\hline Stocks Returnst-1 & $\begin{array}{l}-0.0001 \\
(0.6466)\end{array}$ & $\begin{array}{l}-0.0057^{* * *} \\
(0.0006)\end{array}$ & $\begin{array}{l}0.0005 \\
(0.8313)\end{array}$ & $\begin{array}{l}-0.0001^{* * *} \\
(0.0000)\end{array}$ & $\begin{array}{l}-0.0009^{* * *} \\
(0.0004)\end{array}$ & $\begin{array}{l}-0.0009^{* *} \\
(0.0413)\end{array}$ \\
\hline $\mathrm{VIX}_{\mathrm{t}-1}$ & $\begin{array}{l}0.0001 \\
(0.7586)\end{array}$ & $\begin{array}{l}0.0006+ \\
(0.0937)\end{array}$ & $\begin{array}{l}-0.0002 \\
(0.3281)\end{array}$ & $\begin{array}{l}0.0001^{* * *} \\
(0.0006)\end{array}$ & $\begin{array}{l}0.0004^{* *} \\
(0.0113)\end{array}$ & $\begin{array}{l}0.0009+ \\
(0.0873)\end{array}$ \\
\hline Oil-Prices-1 & & & & $\begin{array}{l}0.0412^{* * *} \\
(0.0000)\end{array}$ & $\begin{array}{l}0.2442^{* * *} \\
(0.0072)\end{array}$ & $\begin{array}{l}0.5199^{* *} \\
(0.0376)\end{array}$ \\
\hline Observations & 3017 & 2113 & 2150 & 3017 & 2113 & 2150 \\
\hline Countries & 7 & 5 & 5 & 7 & 5 & 5 \\
\hline
\end{tabular}

Mean Group Estimator Results, fixed effects included but not reported.

Hamilton (1992) robust standard errors in parenthesis.

P-values in parenthesis, + significant at $10 \% \quad * *$ significant at $5 \% \quad * * *$ significant at $1 \%$. 
Table C6. Effects of Advanced Economies Monetary Policy Measures in UK Portfolio Flows to EMEs

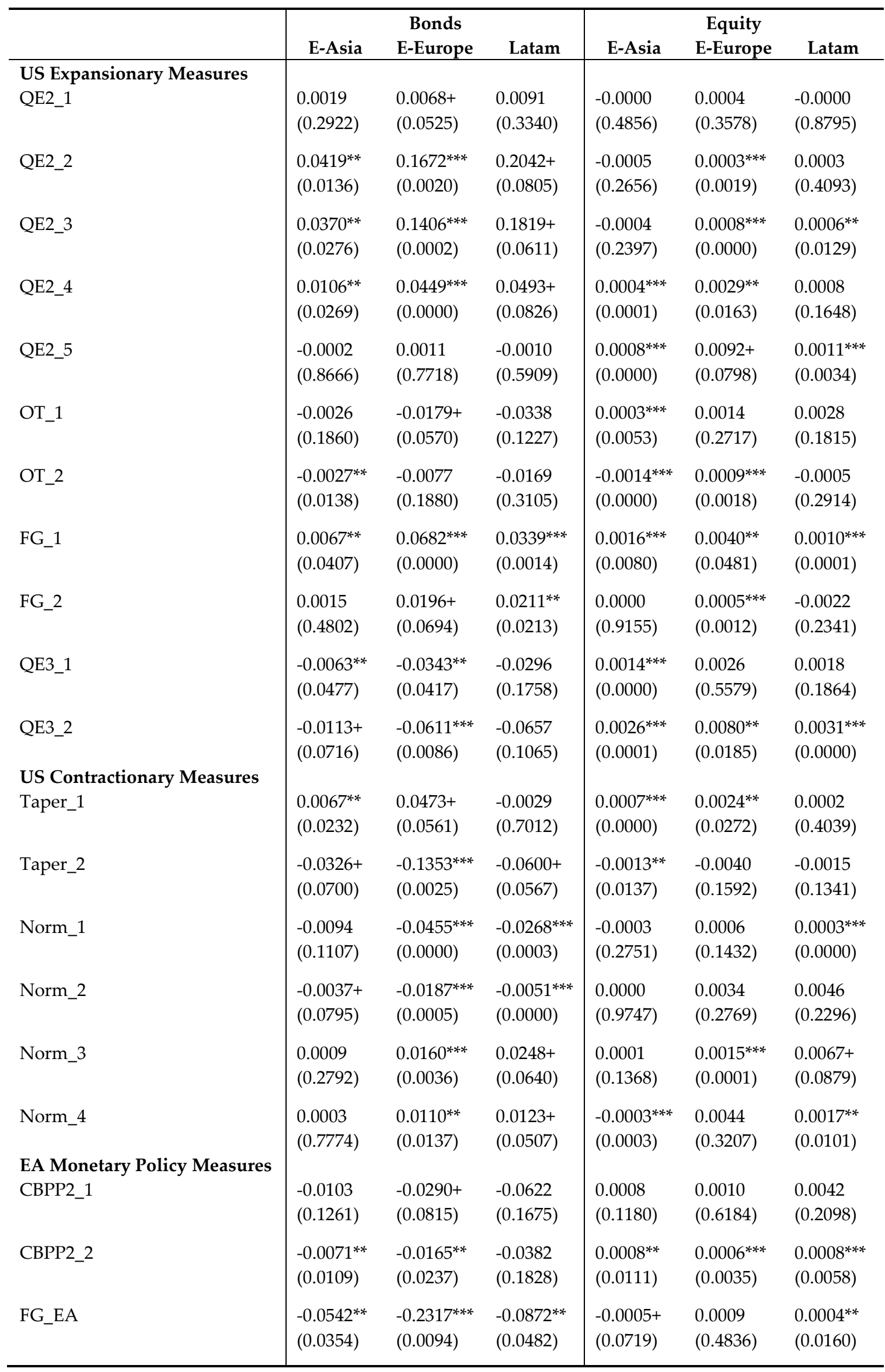




\begin{tabular}{|c|c|c|c|c|c|c|}
\hline PQE & $\begin{array}{l}-0.0009 \\
(0.4040)\end{array}$ & $\begin{array}{l}-0.0173 \\
(0.2504)\end{array}$ & $\begin{array}{l}-0.0079 * * \\
(0.0399)\end{array}$ & $\begin{array}{l}0.0003^{* * *} \\
(0.0032)\end{array}$ & $\begin{array}{l}-0.0006^{* *} \\
(0.0386)\end{array}$ & $\begin{array}{l}-0.0006 \\
(0.1843)\end{array}$ \\
\hline СВРР3 & $\begin{array}{l}0.0014^{* * *} \\
(0.0000)\end{array}$ & $\begin{array}{l}0.0007 \\
(0.6060)\end{array}$ & $\begin{array}{l}-0.0046^{* *} \\
(0.0145)\end{array}$ & $\begin{array}{l}-0.0002 \\
(0.1208)\end{array}$ & $\begin{array}{l}-0.0015 \\
(0.4058)\end{array}$ & $\begin{array}{l}-0.0005^{* * *} \\
(0.0000)\end{array}$ \\
\hline TLTRO1_1 & $\begin{array}{l}0.0048^{* * *} \\
(0.0034)\end{array}$ & $\begin{array}{l}0.0156^{* *} \\
(0.0230)\end{array}$ & $\begin{array}{l}0.0014 \\
(0.6865)\end{array}$ & $\begin{array}{l}0.0014^{* * *} \\
(0.0000)\end{array}$ & $\begin{array}{l}0.0040 \\
(0.1664)\end{array}$ & $\begin{array}{l}-0.0196+ \\
(0.0992)\end{array}$ \\
\hline TLTRO1_2 & $\begin{array}{l}0.0018 \\
(0.4188)\end{array}$ & $\begin{array}{l}0.0210 \\
(0.1403)\end{array}$ & $\begin{array}{l}-0.0152+ \\
(0.0742)\end{array}$ & $\begin{array}{l}-0.0024^{* * *} \\
(0.0000)\end{array}$ & $\begin{array}{l}-0.0095^{* *} \\
(0.0329)\end{array}$ & $\begin{array}{l}-0.0053 \\
(0.1793)\end{array}$ \\
\hline PSPP & $\begin{array}{l}-0.0002 \\
(0.4344)\end{array}$ & $\begin{array}{l}-0.0015 \\
(0.8814)\end{array}$ & $\begin{array}{l}0.0010 \\
(0.8529)\end{array}$ & $\begin{array}{l}-0.0020^{* * *} \\
(0.0001)\end{array}$ & $\begin{array}{l}-0.0032^{* *} \\
(0.0109)\end{array}$ & $\begin{array}{l}-0.0059 \\
(0.1106)\end{array}$ \\
\hline TLTRO2 & $\begin{array}{l}-0.0102^{* *} \\
(0.0117)\end{array}$ & $\begin{array}{l}-0.0246^{* * *} \\
(0.0048)\end{array}$ & $\begin{array}{c}-0.0303+ \\
(0.0503)\end{array}$ & $\begin{array}{l}-0.0002^{* * *} \\
(0.0038)\end{array}$ & $\begin{array}{l}0.0050+ \\
(0.0534)\end{array}$ & $\begin{array}{l}0.0239 \\
(0.2747)\end{array}$ \\
\hline \multicolumn{7}{|c|}{ UK Monetary Policy Measures } \\
\hline APF1_2 & $\begin{array}{l}-0.0071^{* * *} \\
(0.0005)\end{array}$ & $\begin{array}{l}-0.0266 \\
(0.1055)\end{array}$ & $\begin{array}{c}-0.0479+ \\
(0.0841)\end{array}$ & $\begin{array}{l}0.0001 \\
(0.1186)\end{array}$ & $\begin{array}{l}0.0001 \\
(0.8639)\end{array}$ & $\begin{array}{l}0.0001^{* *} \\
(0.0290)\end{array}$ \\
\hline APF1_3 & $\begin{array}{l}-0.0130^{* *} \\
(0.0294)\end{array}$ & $\begin{array}{l}-0.0355^{* * *} \\
(0.0079)\end{array}$ & $\begin{array}{l}-0.0886+ \\
(0.0722)\end{array}$ & $\begin{array}{l}-0.0003^{* *} \\
(0.0140)\end{array}$ & $\begin{array}{l}-0.0009^{* * *} \\
(0.0002)\end{array}$ & $\begin{array}{l}0.0001 \\
(0.1045)\end{array}$ \\
\hline APF2_2 & $\begin{array}{l}0.0359^{* *} \\
(0.0341)\end{array}$ & $\begin{array}{l}0.1165^{* * *} \\
(0.0004)\end{array}$ & $\begin{array}{l}0.1299^{* *} \\
(0.0418)\end{array}$ & $\begin{array}{l}0.0040^{* * *} \\
(0.0000)\end{array}$ & $\begin{array}{l}0.0039+ \\
(0.0872)\end{array}$ & $\begin{array}{l}0.0007^{* *} \\
(0.0314)\end{array}$ \\
\hline APF2_3 & $\begin{array}{l}-0.0117^{* * *} \\
(0.0035)\end{array}$ & $\begin{array}{l}-0.0484^{* * *} \\
(0.0086)\end{array}$ & $\begin{array}{l}-0.0431 \\
(0.1370)\end{array}$ & $\begin{array}{l}0.0002 \\
(0.7531)\end{array}$ & $\begin{array}{l}-0.0040+ \\
(0.0975)\end{array}$ & $\begin{array}{l}-0.0007 \\
(0.2905)\end{array}$ \\
\hline TFS & $\begin{array}{l}-0.0004 \\
(0.6804)\end{array}$ & $\begin{array}{l}0.0140^{* *} \\
(0.0403)\end{array}$ & $\begin{array}{l}0.0234^{* *} \\
(0.0371)\end{array}$ & $\begin{array}{l}-0.0011^{* * *} \\
(0.0088)\end{array}$ & $\begin{array}{l}-0.0039^{* *} \\
(0.0336)\end{array}$ & $\begin{array}{l}0.0061 \\
(0.3066)\end{array}$ \\
\hline \multicolumn{7}{|c|}{ Pull and Push Factors } \\
\hline FX-Growth-Ratet-1 & $\begin{array}{l}-0.0014^{* *} \\
(0.0158)\end{array}$ & $\begin{array}{l}-0.0017^{* *} \\
(0.0164)\end{array}$ & $\begin{array}{l}-0.0042^{* *} \\
(0.0222)\end{array}$ & $\begin{array}{l}-0.0002^{* *} \\
(0.0163)\end{array}$ & $\begin{array}{l}-0.0001 \\
(0.5000)\end{array}$ & $\begin{array}{l}-0.0002^{* * *} \\
(0.0006)\end{array}$ \\
\hline Interest-Rate-Difft-1 & $\begin{array}{l}-0.0004 \\
(0.7909)\end{array}$ & $\begin{array}{l}0.0062 \\
(0.1809)\end{array}$ & $\begin{array}{l}-0.0072^{* *} \\
(0.0260)\end{array}$ & & & \\
\hline Stocks Returnst-1 & & & & $\begin{array}{l}0.0120^{* *} \\
(0.0183)\end{array}$ & $\begin{array}{l}0.0225 \\
(0.2585)\end{array}$ & $\begin{array}{l}0.0214 \\
(0.3938)\end{array}$ \\
\hline $\mathrm{VIX}_{\mathrm{t}-1}$ & $\begin{array}{l}0.0001 \\
(0.5304)\end{array}$ & $\begin{array}{l}-0.0003 \\
(0.6568)\end{array}$ & $\begin{array}{l}0.0015 \\
(0.2090)\end{array}$ & $\begin{array}{l}0.0000^{* *} \\
(0.0186)\end{array}$ & $\begin{array}{l}0.0000^{* * *} \\
(0.0001)\end{array}$ & $\begin{array}{l}0.0000 \\
(0.3359)\end{array}$ \\
\hline Oil-Pricest-1 & $\begin{array}{l}0.0002+ \\
(0.0669)\end{array}$ & $\begin{array}{l}0.0009^{* * *} \\
(0.0001)\end{array}$ & $\begin{array}{l}0.0008^{* *} \\
(0.0455)\end{array}$ & $\begin{array}{l}0.0000 \\
(0.1365)\end{array}$ & $\begin{array}{l}0.0000^{* * *} \\
(0.0000)\end{array}$ & $\begin{array}{l}0.0000+ \\
(0.0968)\end{array}$ \\
\hline $\begin{array}{l}\text { Observations } \\
\text { Countries }\end{array}$ & $\begin{array}{l}3017 \\
7\end{array}$ & $\begin{array}{l}2113 \\
5\end{array}$ & $\begin{array}{l}2150 \\
5\end{array}$ & $\begin{array}{l}3017 \\
7\end{array}$ & $\begin{array}{l}2113 \\
5\end{array}$ & $\begin{array}{l}2150 \\
5\end{array}$ \\
\hline
\end{tabular}

Mean Group Estimator Results, fixed effects included but not reported.

Hamilton (1992) robust standard errors in parenthesis.

P-values in parenthesis, + significant at $10 \% \quad * *$ significant at $5 \% \quad * * *$ significant at $1 \%$. 


\section{References}

Ahmed, S. \& Zlate, A. (2014). Capital flows to emerging market economies: A brave new world? Journal of International Money and Finance, 48, 221-248.

Baek, I.-M., 2006. Portfolio investment flows to A sia and Latin America: Pull, push, or market sentiment? Journal of Asian Economics, 17, 363-373.

Bowman, D., Londono, J. M., \& Sapriza, H., Jun. (2014). US Unconventional Monetary Policy and Transmission to Emerging Market Economies. International Finance Discussion Papers 1109, Board of Governors of the Federal Reserve System (US).

Breitung, J., \& Das, S. (2005). Panel unit root tests under cross-sectional dependence. Statistica Neerlandica, 59, 414-433.

Byrne, J. P. \& Fiess, N. (2011). International capital flows to emerging and developing countries: National and global determinants. SIRE Discussion Papers 2011-03, Scottish Institute for Research in Economics (SIRE).

Calvo, G., Leiderman, L., \& Reinhart, C. M. (1993). Capital inflows and real exchange rate appreciation in Latin America: The role of external factors. IMF Staff Papers, 40 (1), 108-151.

Cerutti, E., Claessens, S., \& Puy, D. (2015). Push factors and capital flows to emerging markets: Why knowing your lender matters more than fundamentals. Working Paper, WP/15/127, IMF.

Chen, J., Mancini Griffoli, T. \& Sahay, R. (2014). Spillovers from United States Monetary Policy on Emerging Markets: Different this Time? Working Paper, WP14/240, IMF.

Dahlhaus, T. \& Vasishtha, G. (2014). The Impact of US Monetary Policy Normalization on Capital Flows to Emerging-Market Economies. Staff Working Papers, 14-53, Bank of Canada.

Driscoll, J. C. \& Kraay, A. C. (1998). Consistent covariance matrix estimation with spatially dependent panel data. The Review of Economics and Statistics, 80 (4), 549-560.

Fernandez-Arias, E. (1996). The new wave of private capital inflows: Push or pull? Journal of Development Economics, 48, 389-418.

Fratzscher, M. (2012). Capital flows push versus pull factors and the global financial crisis. Journal of International Economics, 88 (2), 341-356.

Fratzscher, M., Lo Duca, M., \& Straub, R. (2016). On the international spillovers of us quantitative easing. The Economic Journal, 128 (608), 330-377. http://dx.doi.org/10.1111/ecoj.12435

Hamilton, L. (1992). How robust is a robust regression? Stata Technical Bulletin 2, StataCorp LP.

Hernandez-Vega, M. (2017a). Estimating capital flows to emerging market economies with heterogeneous panels. Macroeconomic Dynamics, 23, 2068-2088. http://doi.org/10-1017/S136510051

Hernandez-Vega, M. (2017b). Portfolio investment and US monetary policy announcements: an event study analysis using high-frequency data from Mexico. Working Paper Series 2017-02, Banco de Mexico.

IMF (2011). Recent experiences in managing capital inflows-cross-cutting themes and possible policy framework. Tech. rep., International Monetary Fund.

IMF (2012). Liberalizing capital flows and managing outflows. Tech. rep., International Monetary Fund.

Jotikasthira, C., Lundblad, C., \& Ramadorai, T. (2012). Asset Fire Sales and Purchases and the International Transmission of Funding Shocks. Journal of Finance, 67 (6), 2015-2050.

Lakonishok, J., Shleifer, A., \& Vishny, R. (1992). The impact of institutional trading on stock prices. Journal of Financial Economics, 32, 23-43.

Lim, J. J., Mohapatra, S., \& Stocker, M., Mar. (2014). Tinker, Taper, QE, Bye? The Effect of Quantitative Easing on Financial Flows to Developing Countries. Policy Research Working Paper Series 6820, The World Bank.

Lo Duca, M. (2012). Modeling the Time-Varying Determinants of Portfolio Flows to Emerging Markets. Working Paper Series 1468, European Central Bank.

Montiel, P. \& Reinhart, C. M. (1999). Do capital controls and macroeconomic policies influence the volume and composition of capital flows? Evidence from the 1990s. Journal of International Money and Finance, 18 (4), 619 635.

Moore, J., Nam, S., \& Suh, M., Tepper, A. (2013). Estimating the impacts of US LSAPs on emerging market economies' local currency bond markets. Staff Reports 595, Federal Reserve Bank of New York.

Park, K. Y. \& Um, J. Y. (2016). Spillover Effects of United States' Unconventional Monetary Policy on Korean Bond Markets: Evidence from High-Frequency Data. The Developing Economies, 54 (1), 27-58. http://dx.doi.org/10.1111/deve.12095

Pesaran, M. H. \& Smith, R. (1995). Estimating long-run relationships from dynamic heterogeneous panels. Journal of Econometrics, 68 (1), 79-113.

Sahay, R., Arora, V. \& Arvanitis, T. (2014). Emerging market volatility: Lessons from the taper tantrum. IMF Staff Discussion Note, SDN/14/09, IMF. 
Sias, R. W. (2004). Institutional herding. The Review of Financial Studies, 17 (1), $165-206$. http://dx.doi.org/10.1093/rfs/hhg035

Taylor, M. P. \& Sarno, L. (1997). Capital flows to developing countries: Long- and short- term determinants. World Bank Economic Review, 11 (3), 451-70.

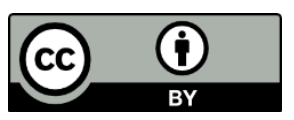

(C) 2020 by the authors. This article is an open-access article distributed under the terms and conditions of the Creative Commons Attribution (CC BY) license (http://creativecommons.org/licenses/by/4.0/). 